\title{
Natural Products as Fungicide and Their Role in Crop Protection
}

\author{
Hiran Kanti Santra and Debdulal Banerjee
}

\begin{abstract}
Seeking solutions from nature for solving one and all problems is the age-old practice for mankind, and natural products are proved to be the most effective one for keeping up the balance of development as well as the "healthy, wealthy, and well" condition of mother nature. Fungal pathogens are proved to be a common and popular contaminant of agroecosystem that approximately causes $70-80 \%$ of total microbial crop loss. To meet the proper global increasing need of food products as a result of population explosion, managing agricultural system in an eco-friendly and profitable manner is the prime target; thus the word "sustainable agriculture" plays it part, and this package is highly effective when coupled with nature-derived fungicidal products that can minimize the event of fungal infections in agrarian ecosystem. Present study enlists the most common and effective natural products that might be of plant or microbial origin, their mode of action, day-by-day development of phytopathogenic resistance against the prevailing fungicides, and also their role in maintenance of sustainability of agricultural practices with special emphasis on their acceptance over the synthetic or chemical one. A large number of bioactive compounds ranging from direct plant (both cryptogams algae and moss and phanerogams)-derived natural extracts, essential oil of aromatic plants, and low-molecular-weight antimicrobial compounds known as phytoalexins to secondary metabolites that are both volatile and nonvolatile organic compounds of microbes (fungal and actinobacterial members) residing inside the host tissue, called endophyte, are widely used as agricultural bioweapons. The rhizospheric partners of plant, mycorrhizae, are also a prime agent of this chemical warfare and protect their green partners from fungal invaders and emphasize the concept of "sustainable agriculture."
\end{abstract}

H. K. Santra · D. Banerjee $(\square)$

Microbiology and Microbial Biotechnology Laboratory, Department of Botany and Forestry, Vidyasagar University, Midnapore, West Bengal, India

e-mail: db@mail.vidyasagar.ac.in 


\section{Keywords}

Sustainable agriculture - Eco-friendly $\cdot$ Bioactive compounds · Algae $\cdot$ Moss ·

Phanerogams $\cdot$ Phytoalexins $\cdot$ Mycorrhizae $\cdot$ Chemical warfare

\subsection{Introduction}

Natural products are the best weapon for the survival of any type of problems regarding infection, pathogenesis, or protection from diseases. Due to their degradability in nature, they are the first options to be used by agriculturalists and plant biologist for combating fungal pathogenesis. The eukaryotic organism fungi have a separate kingdom in Whittaker's five kingdom classification and are prime member of this ecosystem as a potent decomposer. In spite of their heavy and multidimensional applications in agricultural, medicinal, and industrial field ranging from the production of life-saving medicines to food supplements, they are the cause of huge global crop loss each year and lead to economic exhaustion. Macro- and microscopic fungi-producing fruit bodies on different portions of a plant body (stem, leaf, fruit, root) lead to the death and decline of the crop species. Several methods have already been tried since the start of civilization for crop protection but because of plant and fungal coevolution, fungi have dominated on the green eukaryotes and caused significant reduction in the crop yield. Particularly in a country like India where the central GDP largely depends on agricultural output, the fungal pathogenesis has been a matter of grave concern for the agriculture department and policy makers. Huge amount of money and manpower is invested to fight against the fungal diseases for ensuring higher and qualitative yield, but still it has been a burning problem of today's conditions. The problem with chemical and synthetic tools for combating the parasitic infections includes their toxicity leading to quality deterioration and environmental pollution accompanied with side effects on human health. In a case study, it has been reported that the extreme use of antibiotics in agricultural field and their direct consumption by humans through their daily meal have led to resistance of those antibiotics in human fungal pathogens. So we are in search of bioactive agents that will be of biological origin, selective to their host, and produce no secondary symptoms with least negative impact. The problem with fungi is their secretion of various types of mycotoxins (aflatoxins, ochratoxins, patulin, fumonisin, zearalenone, deoxynivalenol, etc.) in the stored food products, causing postharvest loss of cereals, pulses, dry fruits, and spices. Mycotoxins are not only food spoilers but also potent disease-causing agents in humans leading to cancer, liver damage, kidney failure, and paralysis (Miller 1995). The severe effects of fungal crop loss are visible largely in tropical or subtropical regions where the temperature is moderately higher than the other parts of the world. Fungal devastation occurs in two phases: firstly, when the crops are growing on the field and, secondly, when they are stored for further transportation, postharvest loss. The third type of contamination occurs when the microscopic airborne pathogens like molds grow on cooked 
foods and lead to food spoilage. At each and every level, scientists have developed techniques to minimize fungal food loss. On a gross annual estimate, almost $25 \%$ of agricultural food items are of no use due to fungal contamination (Pittet 1998). The major issues with fungi-related crop loss are deterioration as a result of increase of fatty acid conditions, change of color and texture of food items, poor nutritional conditions, and poor germinability of stored seeds (Dhingra et al. 2001). Reports from Asia and Africa include death of humans and animals due to consumption of mycotoxin-contaminated foods (Reddy and Raghavender 2007). Fungal pathogens are sometimes dependent on more than one host for their successful completion of life cycle and disease development (Puccinia graminis var. tritici, causal agent of black stem rust of wheat that requires Berberis aristata for successful infection other than there main target wheat plant). So physical controls like eradication of secondary or collateral host and burning of the old livestocks and remnants of the field are the primary measures adopted by the farmers for disease-free crop production. So maintaining the sustainability along with less pathogenic infection is the deep ecological movement for crop maintenance. There are reports of resistance developed against the common and widely used antibiotics of agricultural importance. Blasticidin S, an antibiotic obtained from Streptomyces sp. (a type of actinobacteria predominantly present in soil samples), interacts with the protein synthesis and causes the death of the rice blast pathogens. Development of resistance of this antibiotic is reported to be present in some fungal pathogens that detoxify it by deamination (Dayan et al. 2009). Compounds of bacterial and fungal origin from both soil and endophytic sources are used as an alternative source over the chemical ones. Plant extracts especially essential oils from plant taxa of Lamiaceae family are of immense importance and are used as fungicidal or fungistatic. Most of the active ingredients act upon the fungal cell wall by either blocking the cellular processes like respiration, cell wall and cell membrane synthesis, ergosterol biosynthesis, protein synthesis, or DNA replication. Not only the secondary metabolites of plant and microbial origin but also the direct application of microorganisms in terms of biocontrol agent could be used as potent antifungals. Other than these, plants' own defense molecules, known as the phytoalexins, could provide a strong line of defense against mycorrhizae; the root symbionts of higher plants can physically, biologically, and biochemically protect the plant root from pathogenic invasion and provide an enhanced resistance conditions to their hosts. This study includes the role of these compounds as natural agents of antifungal property and their role in disease prevention.

\subsection{Mycorrhizae as a Biocontrol Agent}

\subsubsection{Introduction}

Mycorrhiza being the perfect example of symbiosis is known to be the oldest association between higher plant (both angiosperm and gymnosperm, monocot and dicot plants) and fungi and is an astonishing phenomenon of nature. The 
mycorrhizal association is one of nature's privileges for maintaining the sustainability of agriculture. In present day's changing environment, haphazard use of pesticides (fungicides) and chemicals poses a great risk to the existence and survival of mycorrhizal species in its complete biologically active form. There is a need to increase awareness in order to save mycorrhizal fungi from extinction.

Plants form beneficial association with other variants of life forms (animals, bacteria, or fungi) to complete their life processes, to fight against pathogenic microorganisms, and most importantly to thrive in adverse environmental situations. The plant root and its associated living microbial flora are together called "rhizosphere," particularly the area of mycorrhizal occurrence. The term mycorrhiza is derived from two Greek words: mycos which means fungus and rhiza which means roots. In nature, more than $80 \%$ of angiosperms and almost all of gymnosperms are known to have mycorrhizal associations. The common two types of mycorrhizal associations that exist in nature are endomycorrhizae, also called arbuscular mycorrhizae (AM), for example, Endogone sp. and Rhizophagus sp., and ectomycorrhizae (EM), for instance Amanita muscaria and Laccaria bicolor. Mycorrhizal associations support its host plants to survive in untimely soil conditions and drought situations by increasing the surface area of root and efficiency of mineral uptake. Environmental threats including problems of temperature increase, climate changing, drought, and infertility of soil are some of the major challenges in agriculture and have to be mitigated to ensure global food security. In this context, mycorrhiza-based crop production is one of the key components of sustainable agriculture practices.

\subsubsection{Interaction Between AM Fungi and Plant Pathogens}

In most of the cases, AM fungi-mediated suppression of root pathogenic fungi is achieved by either morphological, physiological, or biochemical alterations of the host. Several experiments on fungistatic activity of the mycorrhizal species have been done, and fruitful results are found against pathogenic fungi such as Aphanomyces spp., Botrytis fabae, Chalara (Thielaviopsis) basicola, Dothiorella gregaria, Fusarium oxysporum, Gaeumannomyces graminis var. tritici, Ganoderma pseudoferreum, Pythium ultimum, P. splendens, Phytophthora parasitica, P. cactorum, $P$. vignae, Rhizoctonia solani, $R$. bataticola, and Sclerotium rolfsii (Lioussanne et al. 2009; Bagyaraj 2006; Bagyaraj and Chawla 2012). The most common outcome of AM fungal colonization is seen as an increase in number of branches, resulting in a relatively larger proportion of higher-order roots in the root system. Thickening of the cell walls due to lignification and production of polysaccharides in mycorrhizal plants are the common mode of prevention of penetration and growth of pathogens like Fusarium oxysporum and Phoma terrestris. A huge percentage of AM-root pathogen interaction studies have been conducted in crop plants of agricultural and horticultural importance. But the information available on forest tree species is scanty. Mycorrhizal technology can thus play an important role in production of low-cost quality seedlings and provide plant protection. Like other methods of biological control, AM fungi are not able to offer complete immunity against the 
infection caused by plant pathogens. They could only impart a degree of resistance against soilborne plant pathogens. However, the possibility of biologically controlling soilborne plant pathogens looks promising.

\subsubsection{Enhancement of Plant Defense Mechanism}

AM fungi play a protective role for plants by activating the defense mechanisms for the better resistance of crop plants and thus may protect the host plant from further fungal pathogenic attack, thus working as a potent biocontrol agent. Researchers have proved that AM symbiosis triggers the activation of several defense-related genes and also expression of pathogenesis-related proteins. Evidences are drawn from modern techniques like molecular biology methods and immunological and histochemical analysis that strongly supports this concept. AM fungi first act as a biotrophic agent, and before entering the host plant's root cell, they cause a sharp change in endogenous salicylic acid that is reflected in quick accumulation of reactive oxygen species (ROS), a wide range of hydrolytic enzymes, and also the activation of phenylpropanoid biosynthetic pathway (Güimil et al. 2005, Paszkowski 2006, Roman et al. 2011). Research findings have proved that the amount of defense-related compounds (essential enzymes like PAL, phenylalanine ammonialyase, a product of phenylpropanoid pathway, enzymes needed for flavonoid or isoflavonoid biosynthesis like chalcone isomerase) that act for the protection of plant from fungal and bacterial pathogen is higher in the case of mycorrhiza-inoculated plant than in the uninoculated ones (Volpin et al. 1994, 1995). Host's physiological and biochemical processes are greatly influenced by the mycorrhizal association in terms of decreased root exudation, higher concentration of phenylalanine and serine contents, ortho-dihydroxy phenols, increased membrane phospholipid content, etc. (Smith et al. 1994). When the phospholipid contents are high, it reduces the chances of root pathogenic attack, and higher concentrations of ortho-dihydroxy phenols show inhibitory activity against root rot pathogen Sclerotium rolfsii (causal agent of southern blight), whereas the non-mycorrhizal plants are affected by the southern blight disease. Tomato plants when inoculated with $G$. fasciculatum show inhibitory activity against root knot nematodes. Host-AM association leads to the formation of defense-related compounds like phytoalexins, chitinases (CHI), $\beta$-1,3-glucanase (GLU) (enzyme related to hydrolysis of fungal cell wall), peroxidases (POX), hydroxyproline-rich glycoproteins, and phenolics (St Arnaud and Vujanovic 2007). Synergistic effect of PGPRs along with AM fungi is proved to be a system of better protection than the use of AM fungi alone (Linderman 1994; Bagyaraj and Chawla 2012). Fungal wilt of common medicinal plant Indian coleus (Coleus forskohlii) caused by Fusarium chlamydosporium could be minimized by the joint action of AM fungus and Trichoderma viride and cause a sharp increase in root yield and root forskolin concentration and may also reduce the severe disease conditions (Singh et al. 2012). 


\subsubsection{Change in Rhizospheric Microbial Population}

AM causes a drastic change in the rhizospheric microbiota and intentionally either removes directly the pathogenic microorganisms or stimulates the accumulation of potent microbial partners especially fungus that are heavily antagonistic to the plant pathogenic ones. Plants with mycorrhizal association harbor higher population of rhizospheric microorganisms, thus making it impossible for the pathogen to compete and invade the root. In the case of Phytophthora cinnamomi, the numbers of sporangia and zoospores are found to be reduced when rhizospheric soil extracts of AM plants are applied; it means the AM fungi are able to alter the microbial population and particular functional groups of rhizospheric microorganisms (Meyer and Linderman 1986; Larsen and Bodker 2003). They cause qualitative and quantitative changes in the fungal community by several factors like changed exudation patterns; altered root size and architecture; different physiological and biochemical parameters like sugar, organic acids, and amino acids; and also putative direct AM fungal effects (Toljander et al. 2007; Ahmed et al. 2013; Vigo et al. 2000). Fungistatic siderophore (low-molecular-weight chelating agents having higher affinity for ferric ion)-producing microorganisms are found to be crowded in mycorrhiza-infected roots and rhizospheric regions. Mycorrhizal plants are to be reported with more actinomycetes and bacterial (Gram-positive Paenibacillus sp. against Phytophthora parasitica) flora antagonistic to soilborne root pathogens (Azcon-Aguilar and Barea 1996; Budi et al. 1999).

\subsubsection{Change in Root Anatomy}

Apart from providing biochemical and physiological defense strategies, arbuscular mycorrhizal species also exhibit physical barrier of defense by changing the root anatomy, morphology, and even architecture in terms of increased nutrient uptake, meristematic and nuclear activities of root cell, higher rate of growths, and branching patterns (Atkinson et al. 1994; Gamalero et al. 2010; Gutjahr and Paszkowski 2013). Thus responses of root morphology as a result from AFM colonization seem to depend on plant characters, tap root system, etc. More benefits are seen in tap root system than fibrous root system in terms of gained biomass and nutrient acquisition. Though there is a gap of knowledge in how increased root branching caused by mycorrhizal infection help the plant to defend fungal pathogenesis, synergism is seen as something that can balance the suppressed root growth caused by several root pathogens and restore the root health.

\subsubsection{Enhanced Nutrient Uptake by the Host and Competition Between the Symbiotic Partner and Pathogenic One}

Mycorrhiza-mediated strengthening of the vascular system allows the higher rate of flow of nutrients, increased mechanical strength, and also inactivation of vascular 
pathogens. In conditions of limited resource such as carbon requirement and space for inoculation, a competition between the symbiotic partner (mycorrhizae) and pathogenic fungi is very common and expected (Vos et al. 2014). In the direct warfare, mycorrhizae win over the pathogenic one and thus obtain higher amount of nutrients (almost 4-20\% of total assimilated carbon by host plant) and occupy large areas of available root cortical cells (Jung et al. 2012; Vierheilig et al. 2008). Defeating the pathogenic fungi in terms of nutrient uptake and providing a little or no room for infection are probably the mightiest cause of biocontrol ability of AM fungus (Hammer et al. 2011). Output of AM and Phytophthora interaction indicates that the pathogen does not penetrate cortical arbuscular cells, suggesting that localized competition for infection site does occur between the pathogenic fungi and the AM fungus. Not only fungi but also plant-invading nematodes are in the queue for colonization and nutrient uptake (Smith 1988). The infection of southern root-knot nematode (Meloidogyne incognita, M. exigua) is reduced when the roots are priorly inoculated with symbiotic partners like in the case of coffee plants also (Alban et al. 2013; Dos et al. 2010). Reports have suggested that the number of infected sites is reduced within mycorrhizal root system than in the uninoculated one and thus strongly supports the mycorrhizal role as a biofungicide (Vigo et al. 2000). AM fungi can help the plant uptake of nutrients like phosphate, nitrogen, minerals, microelements (zinc), and water at a higher rate than the uninfected one (Baum et al. 2015; Parniske 2008), and as a result, they are provided with photosynthetic carbon (Smith and Smith 2011). The plants capable of absorbing higher amount of nutrients in terms of AM fungal association have the potential to tolerate pathogenic infections (Karagiannidis et al. 2002). Though the improved nutrition and increased tolerance are not involved in a cause-effect relationship, proofs are there that higher uptake of phosphate results in remarkable reduction in pathogenic infection in mycorrhizal plant but not in non-mycorrhizal plant (Bodker et al. 1998). Tomato plants already infected with Rhizophagus irregularis are not colonized by the pathogen $A$. solani, whereas non-mycorrhizal plant is affected by the pathogen (Fritz et al. 2006). Mixed action of arbuscular mycorrhizal fungi (AMF) Glomus intraradices and Trichoderma harzianum as a biocontrol agent significantly reduces the damping off disease caused by Rhizoctonia solani in the case of tomato seedlings (Amer and Seud 2008).

\subsection{Phytoalexins as Plant Protectants}

\subsubsection{Introduction}

In order to combat parasitic (fungal, bacterial, viral, nematoidal, and insectal) infection like mammalian cells, plant cells also develop defense systems that mediate the release of low-molecular-weight and short-lived (generally 72-96 h of existence) antimicrobial compounds or molecules known as the phytoalexins (Braga 1991; Echiverri et al. 2010; Paxton 1980). These secondary metabolites help the plant to withstand biotic and abiotic stress (Grayer and Kukubun 2001). Most of them being 
Table 9.1 Mode of action of phytoalexin as an antifungal agent

\begin{tabular}{l|l|l|l|l}
\hline Phytoalexin & Host plant & Mode of action & $\begin{array}{l}\text { Target } \\
\text { organism }\end{array}$ & References \\
\hline $\begin{array}{l}\text { Phaseolin or } \\
\text { kievitone }\end{array}$ & $\begin{array}{l}\text { Phaseolus } \\
\text { mungo }\end{array}$ & $\begin{array}{l}\text { Inhibition of glucose } \\
\text { uptake of fungal cell }\end{array}$ & $\begin{array}{l}\text { Rhizoctonia } \\
\text { solani }\end{array}$ & $\begin{array}{l}\text { VanEtten and } \\
\text { Bateman } \\
\text { (1971) }\end{array}$ \\
\hline $\begin{array}{l}\text { Rishitin, } \\
\text { phytuberin, } \\
\begin{array}{l}\text { Anhydro- } \beta- \\
\text { rotunol, } \\
\text { solavetivone }\end{array}\end{array}$ & $\begin{array}{l}\text { Solanum } \\
\text { tuberosum }\end{array}$ & $\begin{array}{l}\text { Loss of motility and } \\
\text { swelling of the zoospores, } \\
\text { formation of cytoplasmic } \\
\text { granules, and bursting of } \\
\text { the cell membrane (leakage } \\
\text { of electrolytes and } \\
\text { metabolites) }\end{array}$ & $\begin{array}{l}\text { Phytophthora } \\
\text { sp. }\end{array}$ & $\begin{array}{l}\text { Harris and } \\
\text { Dennis (1977) }\end{array}$ \\
\hline $\begin{array}{l}\text { Stilbene, } \\
\text { resveratrol, } \\
\text { pterostilbene }\end{array}$ & $\begin{array}{l}\text { Vitis } \\
\text { vinifera }\end{array}$ & $\begin{array}{l}\text { Disorganization of } \\
\text { mitochondria } \\
\text { Disruption of plasma } \\
\text { membrane } \\
\text { Uncoupler of ETS and } \\
\text { blocker of photosynthesis }\end{array}$ & $\begin{array}{l}\text { Botrytis } \\
\text { cinerea }\end{array}$ & $\begin{array}{l}\text { Pezet and Pont } \\
\text { (1990), Adrian } \\
\text { et al. (1997), } \\
\text { Adrian and } \\
\text { Jeandet (2012) }\end{array}$ \\
\hline Camalexin & $\begin{array}{l}\text { Phaseolus } \\
\text { vulgaris }\end{array}$ & $\begin{array}{l}\text { Induction of the fungal } \\
\text { programmed cell death } \\
\text { (PCD) by apoptotic } \\
\text { mechanisms }\end{array}$ & $\begin{array}{l}\text { Botrytis } \\
\text { cinerea }\end{array}$ & $\begin{array}{l}\text { Shlezinger } \\
\text { et al. (2011) }\end{array}$ \\
\hline
\end{tabular}

lipophilic compounds can cross the plasma membrane and act inside the fungal cell causing cytoplasmic granulation of the infecting fungal cells, disorganization of the cellular components, rupture of the plasma membrane, and inhibition of the fungal enzymes and mycelial growth (Cavalcanti 2005). Mode of action of phytoalexins against fungal pathogenesis varies from species to species (Table 9.1). Metabolism of phytoalexin mediated by fungus involves the tendency for its increased polarity by addition of hydroxyl group (oxygenation), removal of methyl group (demethylation), etc. (Jeandet et al. 2014). Muller and Borger first enlightened the concept of phytoalexins almost 70 year ago (Muller and Borger 1940). The first reported case analyzed with the concept of phytoalexin was potato tuber infection by the different strains of causal organism of "late blight of potato," Phytophthora infestans. This pathogenic fungus initiated the hypersensitive reactions that lead to the formation of some "plant secondary metabolite" that inhibited further infection of the same plant when infected with another strain of the same genus of Phytophthora. Muller and his coworker named this "principle" as "phytoalexins" that have protected the plant from secondary infection (Deverall 1982). Accumulation of phytoalexins in the green plant tissue clearly indicates the presence of remarkable amount of fungal and bacterial infections in the host tissue (Stoessl 1980). Phytoalexins are naturally occurring products secreted and accumulated temporarily by plants in response to pathogenic attack or abiotic stress and agents like heavy metal toxicity, UV radiation, and wounds on tissue (Naoumkina et al. 2007). The inducer agent may be of two types, elicitor and elicitin. The elicitors are commonly the oligosaccharides from fungal cell origin (like hepatosaccharide from soja cell wall) (Sharp et al. 
1984). The elicitin types of molecules are generally a type of glycoproteins secreted by the fungal cells (Cordelier et al. 2003). Reports on detailed investigations about phytoalexins have covered a very few families (Leguminosae and Solanaceae) of the green world (Ingham 1982; Kuc 1982). Though investigations on some selected number of species and genera are made from plant families including both monocotyledonous (Amaryllidaceae, Orchidaceae, Poaceae) and dicotyledonous plants (Apiaceae, Asteraceae, Convolvulaceae, Chenopodiaceae, Euphorbiaceae, Linaceae, Moraceae, Piperaceae, Rosaceae, Rutaceae) and even gymnospermic taxa (Ginkgoaceae) (Coxon 1982), cash crops like members of Poaceae (focusing on maize and rice), Vitaceae, and Malvaceae (cotton) have been studied for their phytoalexin production (Schmelz et al. 2014; Langcake and Pryce 1976; Jeandet et al. 2010; Sunilkumar et al. 2006). Though till date a lot of researches have already been performed regarding phytoalexins, a natural weapon against mycopathogens, but still to increase the fungitoxic effectivity of these stress metabolites, further advancement in design and genetic control is needed (Pont and Pezet 1990).

\subsubsection{Biosynthetic Pathways and Regulatory Mechanism}

Phytoalexin synthesis not only is dependent on pathogenic attack but also could be influenced by various abiotic factors such as temperature, humidity, and water availability (Fig. 9.1). There are evidences that different parts of the plant like leaves, flowers, stems, seeds, and root tubers are site of phytoalexin biosynthesis (Mikkelsen et al. 2003). Different biochemical pathways are used for producing various types of phytoalexins. The three most common pathways include (i) the

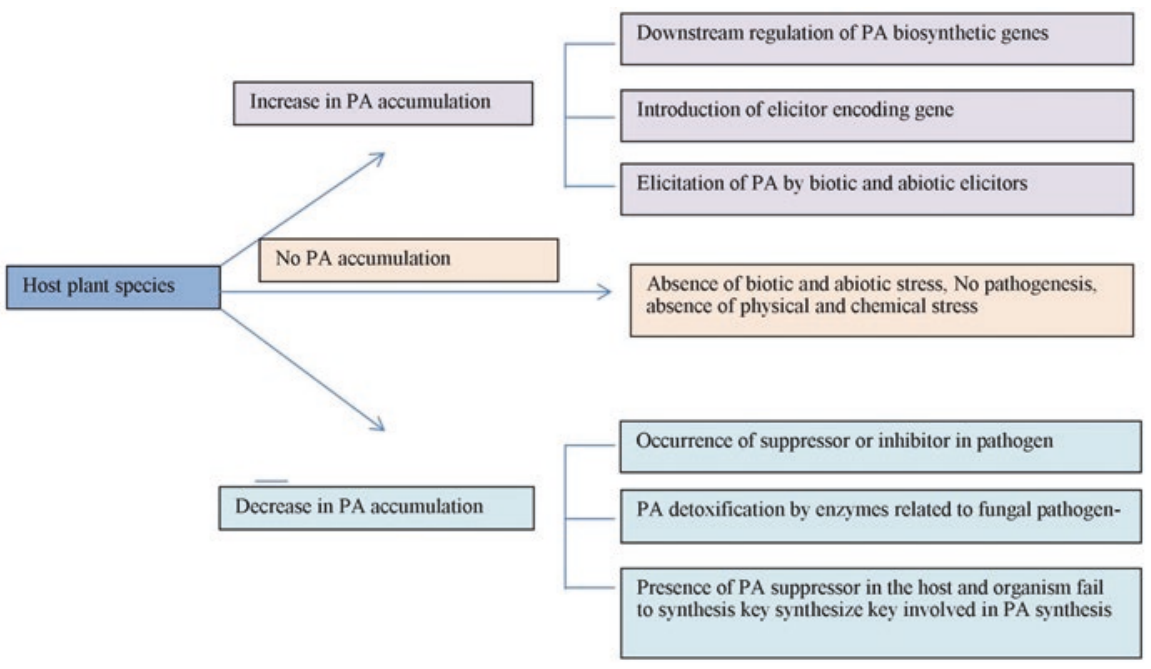

Fig. 9.1 PA production in host plant species is regulated by the interaction between the plant and pathogenic microbes 
phenylpropanoic-polymalonic acid pathway, (ii) the methylerythritol phosphate (MEP) and geranylgeranyl diphosphate (GGDP) route, and (iii) the indole phytoalexin (IP) pathway (Jeandet et al. 2014). It is not always obvious that phytoalexins could be categorized not only by their chemical structure or biosynthetic pathway but also by their function and tissue specificity. Examples include the occurrence of momilactone A on different plant parts of rice plant (Lee et al. 1999; Cartwright 1981). Momilactone A is known to be residing in rice husks and rice stems constitutively, but they are also a phytoalexin of rice leaves. Further studies by Toyomasu and his coworkers conclude that momilactone A is constitutively synthesized and oozed out from root of rice plants. Still there is no sufficient data available to consider phytoalexins as ubiquitous throughout the whole plant kingdom. A lot of studies have revealed their complex biochemical synthetic machinery that involves their de novo synthesis, regulation, and mode of action (Jeandet et al. 2013 Ahuja et al. 2012). Regulatory mechanisms involve defense-related marker genes, calcium sensors, hormone signaling, phosphorylation cascades, and also their antipathogenic activity. There are reports on genetic engineering-mediated manipulation of phytoalexin production and increased disease resistance in the case of plants (Delaunois et al. 2009; Jeandet et al. 2012, 2013).

\subsubsection{Fungal Pathogenesis: A Stimulus for Phytoalexins Production}

Phytoalexins are secondary or stress metabolites that are produced when the host plant is infected with pathogenic fungus. Phytoalexin-mediated defense response includes the expression of lytic enzymes such as chitinases and glucanases and a number of pathogenesis-related (PR) proteins, oxidizing agents, and lignification of cell walls (Dixon and Lamb 1999). Mode of action of phytoalexin involves the coordinated synergism between several defense factors for the effective inhibition of the fungal pathogen (Purkayastha 2017; Mansfield 1999). In the case of Sorghum plant, significant infection caused by Fusarium proliferatum and Fusarium thapsinum stimulates the production of 3-deoxyanthocyanidin, apigeninidin, and luteolinidin and also the concentration of defense-related proteins like peroxidases, $\beta-1,3$ glucanases, and chitinases that help to fight the pathogenic infection (Huang and Backhouse 2004). Similarly, phytocassanes A, B, C, D, and E are produced as a result of Magnaporthe oryzae, Rhizoctonia solani, and Phytophthora infestans infections on rice plants. Remarkably phytocassane E, and momilactones A and B exert in vitro antifungal activity against Magnaporthe oryzae, Botrytis cinerea, Fusarium solani, Fusarium oxysporum, and Colletotrichum gloeosporioides (Koga et al. 1997; Fukuta et al. 2007). There are several ways of blocking the fungal infection in host plant tissues by phytoalexin-mediated response. That includes inhibition of fungal spore on the leaf surface and inhibition during and after penetration to host cell (Usman et al. 2018). The occurrence of fungal germ tube on the leaf surface and diffusion of fungal metabolites through the leaf cells cause the accumulation of phytoalexins by the underlying cells and provide the first line of induced chemical 
defense (VanWees et al. 2003). Phytoalexins may be located on papillae or cell walls, thereby producing a localized, fungitoxic barrier to penetration (Friend 2016). Examples include occurrence of fungitoxic (against Erysiphe graminis) flavonoid (thought to be phytoalexin) on papillae of resistant barley leaves.

\subsubsection{Fungal and Green Plant Extracts: In Vivo Inducers of Phytoalexins Production}

Phytoalexins are known to be solely produced as a result of induction or stimulus by external agents. Fruitful evidences could be drawn regarding this fact. Induction of disease resistance in plants is developed through the direct and indirect involvement of elicitors. Extracts of fungal basidiocarp, essential oils of aromatic plants (Walters et al. 2013), and also synthetic chemicals like aminobutyric acid, salicylic acid, jasmonic acid, and acibenzolar-S-methyl (Garcia-Mier et al. 2013) are the inducers of phytoalexins production. Preparations of horse tail pteridophytic genus Equisetum sp. induce the production of glyceolin in soybean plant (Glycine max) cotyledons and significantly reduce the Rhizoctonia solani infection (Guimaraes et al. 2015). Further studies include the effect of aqueous extracts of basidiocarps of Agaricus blazei, Lentinula edodes, and Pycnoporus sanguineus (Arruda et al. 2012) on the production of glyceollins. Deoxyanthocyanidins and glyceolins are also synthesized by the tinctures of medicinal plants like Ruta graveolens, Origanum majorana, Baccharis trimera (Matiello and Bonaldo 2013), Hymenolobium petraeum, Qualea albiflora, and Corymbia citriodora (Matiello et al. 2016) that act as the elicitors of deoxyanthocyanidins and glyceolin production. Homeopathic preparations of species of Calcarea (C. citriodora and Calcarea carbonica), essential oils of Eucalyptus globulus (Telaxka et al. 2014; Oliveira et al. 2014), and mild concentrations of salicylic acid (Durango et al. 2013) are major elicitins of pistain production and accumulation in cotyledons of common bean (Phaseolus vulgaris). Silicon-mediated enhancement of disease resistance by peroxidase (POX), polyphenol oxidase (PPO), chitinases (CHI), $\beta$-1,3-glucanases (GLU), and phenylalanine ammonia-lyase (PAL) is found in the case of leaf spot of cotton plant caused by Ramularia areola (Curvêlo et al. 2013).

\subsubsection{Modern Approaches Involving Amphibians' Extract as Defense Inducers of Plants}

Southern Amazonian amphibian family Bufonidae represents the true toads, and their cutaneous secretions are of diverse source of bioactive compounds which can be fruitful as new chemical weapons for agrochemical development. Use of elicitors in the case of crop protection nowadays is becoming a very popular method of inducing response which are proved to be durable and broad-spectrum disease control mechanism where the plant's own resistance is used. A group of seven Brazilian scientists (Deice et al. 2019) evaluated the possibilities of methanolic extracts of 
cutaneous secretions of two species of Bufonidae, Rhaebo guttatus and Rhinella marina, on synthesis of phytoalexins named glyceolin (soybean plant), deoxyanthocyanidins (Sorghum plants), and phaseolin (mung plant) in soybean cotyledons, sorghum mesocotyls, and bean hypocotyls, respectively. There is a direct relationship between the phytoalexins production and defense ability of the host plant against the fungal pathogenesis. Studies reveal that when the phytoalexin glyceolin is produced in higher amount in the soybean plant (cultivar TMG 132 RR) as a result of methanolic extracts of amphibian's ( $R$. guttatus) cutaneous secretion (at a concentration of $0.2 \mathrm{mg} / \mathrm{mL}$ ), stimulates the enzyme $\beta$-1,3-glucanase that can cause the hydrolysis of the fungal cell wall along with other defense-related enzymes (chitinase) is also produced in higher amount, but when suppression of glyceolin occurs, that particular enzyme is also not produced. There are evidences in the case of Glycine max that the effectivity of phytoalexins varies from cultivar to cultivar. Application of $R$. marina (amphibian) methanolic extracts induced glyceolin production in TMG 132 RR and Monsoy 8372 cultivars IPRO but did not induce TMG 132 RR cultivars to synthesize these defense-related compounds.

\subsubsection{Phytoalexins Versus Phytopathogenic Fungi: A Direct Chemical Warfare}

Less toxicity of phytoalexins than chemical fungicides is the reason for their universal acceptance. For over 75 years, phytoalexins have been a detailed area of study for its antimicrobial activity, especially antifungal properties. Several investigations include the in vivo bioeffectivity of the phytoalexins against serious plant pathogenic fungi (Table 9.2). Phytoalexin synthesizing genes have also been genetically modified to cope up with the pathogenic evolution. Still reports are there that include examples of cruciferous phytoalexins detoxification by fungal enzymes (Pedras and Abdoli 2017). Modification of pathogen to overcome phytoalexinmediated damage includes curved germ tubes as a result of asymmetric growth of the germ tube. Phytoalexins are natural products of diverse chemical nature, for example, alkaloids, coumarins, isoflavonoid (coumestans, isoflavans, isoflavones, isoflavanones, pterocarpans, pterocarpenes), lignans, polyacetylenes, pterocarpons (pisatin, phaseolin, glyceollin, medicarpin, and maackiain), terpenes, and non-isoflavonoid compounds (furanoacetylenes and stilbenes) (Fig. 9.2) (Grayer and Kokubun 2001). Both in vitro and in vivo fungicidal activity are shown by sakuranetin (rice phytoalexins) against the blast fungus (Hasegawa et al. 2014). Reduction of green mold (caused by Penicillium digitatum) infections is achieved by the action of coumarin type of phytoalexin (scopoletin) of orange (Sanzani et al. 2014). The loss of apples production caused by Penicillium expansum and accumulation of patulin is minimized by the action of phenolic phytoalexins like resveratrol, scopoletin, scoparone, and umbelliferone (Sanzani et al. 2009). In the case of Medicago sativa (alfalfa), the isoflavonoid 7-O-methyltransferase provides increased resistance against Phoma medicaginis by synthesizing maiackiain (He and Dixon 2000). For soybean plants, transformation of resveratrol to pterostilbene 
Table 9.2 Production of phytoalexin by host plant species in response to pathogenic fungal infection

\begin{tabular}{|c|c|c|c|}
\hline Fungal pathogen & Name of phytoalexin & Host & References \\
\hline $\begin{array}{l}\text { Phytophthora } \\
\text { drechsleri }\end{array}$ & $\begin{array}{l}\text { Trans-trans-3,11-tridecadiene- } \\
\text { 5,7,9-triyne-1,2-diol }\end{array}$ & $\begin{array}{l}\text { Carthamus } \\
\text { tinctorius } \\
\text { (safflower) } \\
\text { (Asteraceae) }\end{array}$ & $\begin{array}{l}\text { Allen and } \\
\text { Thomas (1971) }\end{array}$ \\
\hline $\begin{array}{l}\text { Helminthosporium } \\
\text { turcicum }\end{array}$ & Sativin, vesitol & $\begin{array}{l}\text { Alfalfa (Medicago } \\
\text { sativa), bird's-foot } \\
\text { trefoil (Lotus } \\
\text { corniculatus) } \\
\text { (Nymphaeaceae) }\end{array}$ & $\begin{array}{l}\text { Bonde et al. } \\
\text { (1973) }\end{array}$ \\
\hline $\begin{array}{l}\text { Ceratocystis } \\
\text { fimbriata }\end{array}$ & $\begin{array}{l}\text { Ipomeamarone } \\
\text { Xanthotoxin Polyacetylenes/ } \\
\text { falcarinol Phenolics: } \\
\text { xanthotoxin and } \\
\text { 6-methoxymellein } \\
\end{array}$ & $\begin{array}{l}\text { Sweet potato } \\
\text { (Ipomoea batatas) } \\
\text { (Chenopodiaceae) } \\
\text { Pastinaca sativa } \\
\text { (parsnip root) }\end{array}$ & Johnson (1973) \\
\hline $\begin{array}{l}\text { Cercospora } \\
\text { beticola }\end{array}$ & $\begin{array}{l}\text { 2',5-Dimethoxy-6,7- } \\
\text { methylenedioxyflavanone, } \\
\text { 2'-hydroxy-5-methoxy-6,7- } \\
\text { methylenedioxyisoflavone, } \\
\text { betagarin, isoflavones, } \\
\text { betavulgarin }\end{array}$ & $\begin{array}{l}\text { Beta vulgaris } \\
\text { (Chenopodiaceae) }\end{array}$ & Geigert (1973) \\
\hline $\begin{array}{l}\text { Hendersonula sp., } \\
\text { Phytophthora sp. }\end{array}$ & Xanthoxylin & $\begin{array}{l}\text { Citrus limon } \\
\text { (Rutaceae) }\end{array}$ & $\begin{array}{l}\text { Hartmann and } \\
\text { Niehaus (1974) }\end{array}$ \\
\hline $\begin{array}{l}\text { Rhizopus stolonifer, } \\
\text { Aspergillus niger, } \\
\text { Fusarium } \\
\text { moniliforme }\end{array}$ & Diterpenes, casbane & $\begin{array}{l}\text { Ricinus communis } \\
\text { (Euphorbiaceae) }\end{array}$ & $\begin{array}{l}\text { Sitton and } \\
\text { West (1975) }\end{array}$ \\
\hline $\begin{array}{l}\text { Phytophthora } \\
\text { infestans }\end{array}$ & $\begin{array}{l}\text { Dihydrophenanthrenes } \\
\text { (loroglossol) }\end{array}$ & $\begin{array}{l}\text { Loroglossum } \\
\text { hircinum } \\
\text { (Orchidaceae) }\end{array}$ & Ward (1975) \\
\hline Melampsora lini & $\begin{array}{l}\text { Coniferyl alcohol, coniferyl } \\
\text { aldehyde }\end{array}$ & \begin{tabular}{|l} 
Linum \\
usitatissimum \\
(Linaceae) \\
\end{tabular} & $\begin{array}{l}\text { Keen and } \\
\text { Littlefield } \\
(1975) \\
\end{array}$ \\
\hline Botrytis cinerea & $\begin{array}{l}\text { Flavans, 7-hydroxyflavan, } \\
\text { 7,4'-dihydroxyflavan, } \\
\text { 7,4'-dihydroxy-8-methylflavan, } \\
\text { trans-resveratrol } \\
\left(4,3^{\prime}, 5^{\prime} \text {-trihydroxy stilbene), }\right. \\
\text { 6-methoxymellein, } \\
\text { p-hydroxybenzoic acid, } \\
\text { polyacetylene falcarinol }\end{array}$ & $\begin{array}{l}\text { Daffodil (Narcissus } \\
\text { sp.) } \\
\text { (Amaryllidaceae) } \\
\text { Vitis vinifera, grape } \\
\text { vine (Vitaceae) } \\
\text { Carrot root }\end{array}$ & $\begin{array}{l}\text { Langcake and } \\
\text { Pryce (1976), } \\
\text { Coxon (1980), } \\
\text { and Harding } \\
\text { and Heale } \\
\text { (1981) }\end{array}$ \\
\hline
\end{tabular}


Table 9.2 (continued)

\begin{tabular}{|c|c|c|c|}
\hline Fungal pathogen & Name of phytoalexin & Host & References \\
\hline Fusarium solani & $\begin{array}{l}\text { Furanopterocarpans, moracins } \\
\text { E, F, G, and H }\end{array}$ & $\begin{array}{l}\text { Morus alba } \\
\text { (Moraceae) }\end{array}$ & $\begin{array}{l}\text { Takasugi } \\
\text { (1979) }\end{array}$ \\
\hline Bipolaris leersiae & $\begin{array}{l}\text { Brassicanal A } \\
\text { Brassicanal C } \\
\text { Brassinin } \\
\text { Cyclobrassinin } \\
\text { Dehydro-4- } \\
\text { methoxycyclobrassinin, } \\
\text { dioxibrassinin } \\
\text { 1-Methoxybrassenin } \\
\text { 4-Methoxybrassinin } \\
\text { 1-Methoxyspirobrassinol } \\
\text { Methyl ether }\end{array}$ & $\begin{array}{l}\text { Brassica oleracea } \\
\text { B. rapa } \\
\text { B. napus } \\
\text { B. carinata } \\
\text { (Brassicaceae) }\end{array}$ & $\begin{array}{l}\text { Takasugi et al. } \\
(1986),(1988) ; \\
\text { Monde et al. } \\
(1990 \mathrm{a}, \mathrm{b}), \\
(1991),(1994) ; \\
\text { and Gross } \\
\text { et al. (1994) }\end{array}$ \\
\hline Phoma lingam & $\begin{array}{l}\text { Brassicanal A } \\
\text { Brassilexin } \\
\text { Camalexin } \\
\text { Cyclobrassinin } \\
\text { Methyl } \\
\text { 1-methoxyindole-3-carboxylate } \\
\text { Spirobrassinin }\end{array}$ & $\begin{array}{l}\text { B. rapa, } B . \\
\text { campestris } \\
\text { B. carinata } \\
\text { Capsella } \\
\text { bursa-pastoris } \\
\text { B. napus } \\
R . \text { sativus } \\
\text { (Brassicaceae) }\end{array}$ & $\begin{array}{l}\text { Devys et al. } \\
\text { (1988), Dahiya } \\
\text { and Rimmer } \\
\text { (1988), } \\
\text { Browne et al. } \\
\text { (1991), Conn } \\
\text { et al. (1994), } \\
\text { Pedras and } \\
\text { Khan (1996), } \\
\text { Pedras et al. } \\
\text { (1997), and } \\
\text { Pedras and } \\
\text { Sorensen } \\
\text { (1998) }\end{array}$ \\
\hline $\begin{array}{l}\text { Sclerotinia } \\
\text { sclerotiorum }\end{array}$ & Cyclobrassinin & $\begin{array}{l}\text { B. napus } \\
\text { (Brassicaceae) }\end{array}$ & $\begin{array}{l}\text { Dahiya and } \\
\text { Rimmer (1988) }\end{array}$ \\
\hline Cladosporium sp. & $\begin{array}{l}\text { Camalexin, } \\
\text { Cyclobrassininsulfoxide } \\
\text { 1-Methoxycamalexin } \\
\text { 6-Methoxycamalexin }\end{array}$ & $\begin{array}{l}\text { A. thaliana } \\
\text { B. carinata } \\
\text { (Brassicaceae) }\end{array}$ & $\begin{array}{l}\text { Devys and } \\
\text { Barbier (1990) }\end{array}$ \\
\hline $\begin{array}{l}\text { Alternaria } \\
\text { brassicae }\end{array}$ & $\begin{array}{l}\text { Camalexin } \\
\text { 1-Methoxybrassinin } \\
\text { 6-Methoxycamalexin }\end{array}$ & $\begin{array}{l}\text { Arabidopsis } \\
\text { thaliana } \\
\text { B. napus } \\
\text { B. oleracea } \\
\text { C. bursa-pastoris } \\
\text { Camelina sativa } \\
\text { (Brassicaceae) }\end{array}$ & $\begin{array}{l}\text { Browne et al. } \\
\text { (1991), Tsuji } \\
\text { et al. (1992), } \\
\text { and Gross } \\
\text { et al. (1994) }\end{array}$ \\
\hline Rhizoctonia solani & $\begin{array}{l}\text { Camalexin } \\
\text { Cyclobrassinin }\end{array}$ & $\begin{array}{l}\text { C. bursa-pastoris } \\
\text { B. napus } \\
\text { (Brassicaceae) }\end{array}$ & $\begin{array}{l}\text { Browne et al. } \\
\text { (1991) }\end{array}$ \\
\hline Pythium ultimum & $\begin{array}{l}\text { Cyclobrassinin } \\
\text { 1-Methoxybrassinin }\end{array}$ & $\begin{array}{l}\text { B. napus } \\
\text { B. oleracea } \\
\text { (Brassicaceae) }\end{array}$ & $\begin{array}{l}\text { Conn et al. } \\
\text { (1994) }\end{array}$ \\
\hline
\end{tabular}


Table 9.2 (continued)

\begin{tabular}{|c|c|c|c|}
\hline Fungal pathogen & Name of phytoalexin & Host & References \\
\hline $\begin{array}{l}\text { Cladosporium } \\
\text { cucumerinum }\end{array}$ & $\begin{array}{l}\text { 1-methoxybrassinin, } \\
\text { 1-methoxyspirobrassinin, } \\
\text { cyclobrassinone, sinalexin, } \\
\text { spirobrassinin }\end{array}$ & $\begin{array}{l}\text { B. oleracea } \\
\text { B. carinata } \\
\text { B. juncea } \\
\text { (Brassicaceae) }\end{array}$ & $\begin{array}{l}\text { Gross et al. } \\
\text { (1994) }\end{array}$ \\
\hline $\begin{array}{l}\text { Phomopsis } \\
\text { perniciosa }\end{array}$ & $\begin{array}{l}\text { Biphenyls, auarperin, } \\
\text { dibenzofurans, cotonefurans }\end{array}$ & $\begin{array}{l}\text { Aronia sp., } \\
\text { Chaenomeles sp., } \\
\text { Eriobotrya sp., } \\
\text { Malus sp. } \\
\text { (Rosaceae) }\end{array}$ & $\begin{array}{l}\text { Kokubun and } \\
\text { Harborne } \\
\text { (1995) }\end{array}$ \\
\hline Pyricularia oryzae & $\begin{array}{l}\text { Brassinin } \\
\text { Spirobrassinin }\end{array}$ & $\begin{array}{l}\text { B. napus } \\
\text { B. carinata } \\
\text { (Brassicaceae) }\end{array}$ & $\begin{array}{l}\text { Storck and } \\
\text { Sacristan } \\
\text { (1995) }\end{array}$ \\
\hline Erwinia carotovora & Camalexin & $\begin{array}{l}\text { C. bursa-pastoris } \\
\text { (Brassicaceae) }\end{array}$ & $\begin{array}{l}\text { Jimenez et al. } \\
\text { (1997) }\end{array}$ \\
\hline $\begin{array}{l}\text { Fusarium } \\
\text { oxysporum }\end{array}$ & Camalexin & $\begin{array}{l}\text { Arabis lyrata } \\
\text { (Brassicaceae) }\end{array}$ & $\begin{array}{l}\text { Zook et al. } \\
\text { (1998) }\end{array}$ \\
\hline Bipolaris maydis & $\begin{array}{l}\text { 3-Deoxyanthocyanidin, } \\
\text { apigeninidin, luteolinidin, and } \\
\text { apigeninidin 5-O-arabinoside }\end{array}$ & $\begin{array}{l}\text { Sorghum bicolor } \\
\text { (Poaceae) }\end{array}$ & $\begin{array}{l}\text { Wharton and } \\
\text { Nicholson } \\
(2000)\end{array}$ \\
\hline $\begin{array}{l}\text { Fusarium } \\
\text { proliferatum, } F . \\
\text { thapsinum }\end{array}$ & Apigeninidin, luteolinidin & $\begin{array}{l}\text { Sorghum sp. } \\
\text { (Poaceae) }\end{array}$ & $\begin{array}{l}\text { Huang and } \\
\text { Backhouse } \\
(2004)\end{array}$ \\
\hline Puccinia coronata & Avenalumins I, II, III & Barley (Poaceae) & $\begin{array}{l}\text { Chaube and } \\
\text { Pundhir (2005) }\end{array}$ \\
\hline $\begin{array}{l}\text { Monilinia } \\
\text { fructicola }\end{array}$ & Trifolirhizin & $\begin{array}{l}\text { Red clover } \\
\text { (Trifolium pretense) } \\
\text { (Fabaceae) }\end{array}$ & $\begin{array}{l}\text { Chaube and } \\
\text { Pundhir (2005) }\end{array}$ \\
\hline $\begin{array}{l}\text { Penicillium } \\
\text { expansum }\end{array}$ & $\begin{array}{l}\text { Resveratrol, scopoletin, } \\
\text { scoparone, umbelliferone }\end{array}$ & $\begin{array}{l}\text { Apple (Malus sp.) } \\
\text { (Rosaceae) }\end{array}$ & $\begin{array}{l}\text { Sanzani et al. } \\
\text { (2009) }\end{array}$ \\
\hline $\begin{array}{l}\text { Mycosphaerella } \\
\text { fijiensis (black } \\
\text { Sigatoka disease) }\end{array}$ & Irenolone, musanolones & $\begin{array}{l}\text { Banana (Musa sp.) } \\
\text { (Musaceae) }\end{array}$ & $\begin{array}{l}\text { Echeverri et al. } \\
\text { (2012) }\end{array}$ \\
\hline $\begin{array}{l}\text { Phytophthora } \\
\text { megasperma }\end{array}$ & Glyceollin & $\begin{array}{l}\text { Soybean (Glycine } \\
\text { max) (Fabaceae) }\end{array}$ & $\begin{array}{l}\text { Ng et al. } \\
\text { (2011) }\end{array}$ \\
\hline $\begin{array}{l}\text { Fusarium } \\
\text { graminearum } \\
\text { Cochliobolus } \\
\text { heterostrophus, } \\
\text { Rhizopus } \\
\text { microsporus, } \\
\text { Colletotrichum } \\
\text { sublineolum, } \\
\text { Aspergillus flavus, } \\
\text { Aspergillus sojae, } \\
\text { Ustilago maydis }\end{array}$ & $\begin{array}{l}\text { Zealexins (sesquiterpinoid) } \\
\text { Zealexins A1, A2, A3, B1 }\end{array}$ & $\begin{array}{l}\text { Zea mays (maize) } \\
\text { (Poaceae) }\end{array}$ & $\begin{array}{l}\text { Huffaker et al. } \\
\text { (2011) }\end{array}$ \\
\hline
\end{tabular}


Table 9.2 (continued)

\begin{tabular}{|c|c|c|c|}
\hline Fungal pathogen & Name of phytoalexin & Host & References \\
\hline $\begin{array}{l}\text { Cochliobolus } \\
\text { victoriae } \\
\text { Fusarium sp. }\end{array}$ & $\begin{array}{l}\text { Diterpenes (solenoids), } \\
\text { momilactones } A, B \text {, } \\
\text { phytocassane A-E, flavonoids } \\
\text { (5,4-dihydroxy-7- } \\
\text { methoxyflavanone0 }\end{array}$ & $\begin{array}{l}\text { Oryza sativa (rice) } \\
\text { (Poaceae) }\end{array}$ & $\begin{array}{l}\text { Ahuja et al. } \\
\text { (2012) }\end{array}$ \\
\hline Botrytis fabae & Wyerone & $\begin{array}{l}\text { Pea (Pisum } \\
\text { sativum) (Fabaceae) }\end{array}$ & $\begin{array}{l}\text { Slusarenko } \\
\text { et al. (2012) }\end{array}$ \\
\hline $\begin{array}{l}\text { Penicillium } \\
\text { digitatum (green } \\
\text { mold symptoms) }\end{array}$ & Scopoletin & $\begin{array}{l}\text { Orange (Citrus } \\
\text { sinensis) } \\
\text { (Rutaceae) }\end{array}$ & $\begin{array}{l}\text { Sanzani et al. } \\
(2014)\end{array}$ \\
\hline Rhizoctonia solani & Pterostilbene & $\begin{array}{l}\text { Soybean (Glycine } \\
\text { max) (Fabaceae) }\end{array}$ & $\begin{array}{l}\text { Zernova et al. } \\
\text { (2014) }\end{array}$ \\
\hline
\end{tabular}<smiles>Oc1ccc(/C=C/c2cc(O)cc(O)c2)cc1</smiles>

Trans- resveratrol<smiles>COc1c2occc2cc2ccc(=O)oc12</smiles>

Xanthotoxin<smiles>CSc1[nH]c2ccccc2c1C=O</smiles>

Brassicanal A

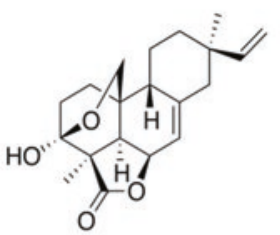

Momilactone B

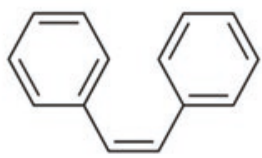

Stilbene

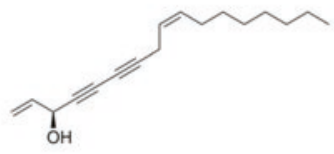

Falcarinol

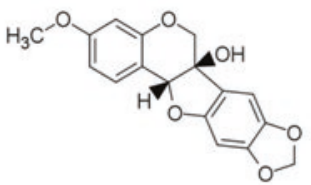

Pisatin

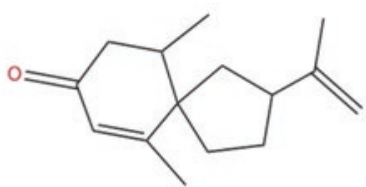

Solavetivone

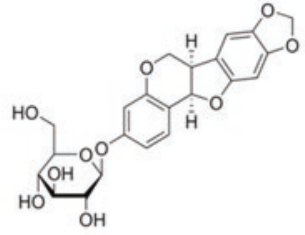

Triflorrhizin<smiles>COc1cc2ccc(=O)oc2cc1OC</smiles>

Scoparone<smiles>Cc1cc2c(C(C)C)c(O)c(O)c(C=O)c2c(O)c1-c1c(C)cc2c(C(C)C)c(O)c(O)c(C=O)c2c1O</smiles>

Gossypol

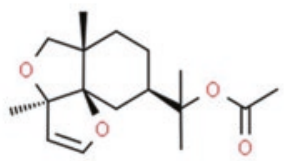

Phytuberin

Fig. 9.2 Different types of phytoalexins having major role in plant protection 
includes protection against Rhizoctonia solani (Zernova et al. 2014). Scientists have proven that not only fungal infection acts as the stimulus for phytoalexin synthesis but also the hormone levels; phosphorylation cascades play a major role in this purpose. Cytokinin overexpression in Nicotiana tabacum is directly associated with its resistance against $P$. syringe by higher concentration of capsidiol and scopoletin (Grosskinsky et al. 2011.) The fungitoxicity of the phytoalexin could be enhanced by methylation or presence of electron-attracting groups on aromatic rings that is directly involved in affinity with membrane proteins being an uncoupler of ETS system.

\subsection{Endophytes: An Untapped Source of Biofungicides}

Endophytes are a type of hidden beneficial microorganisms that reside within the host plant causing no visible disease symptoms and syndrome and promote the plant to maintain its existence in typical harsh conditions. Sometimes they could be latent pathogens at a very distant path of the host's life cycle but are simply a unique area of research where plant science and their microbial association get new definition. Endophytes have been a constant and reliable source of exploration of bioactive compounds, but extensive search has not been performed till date, and that has given the endophyte biologists a great opportunity to search endophytic fungal and actinobacterial flora for the establishment of novel bioactive compounds. Selection of plant for endophytic isolation is the most vital part of this study. Exploitation of the proper isolates accelerates this search and opens up new angle of research. The search for uncommon products of agrochemical importance is a common demand of todays' world. The safer the antifungal agents become, the more it is well accepted in the scientific community as well as agricultural market. In general, the screening of thousands of natural products ends up giving only one commercial product. So indeed it's a tough job to end the search of new antibiotics with a hopeful result. A total of 6 out of 20 of the popular prescribed medicines are of fungal origin, and it is a fact that $5 \%$ of the fungi have been described till date (Hawksworth 1991, 2001). So fungi serve as a continuous dependable source of new natural products. The intelligent screening procedure includes the selection of fungal flora of endophytic sources to open up the untapped potential of secondary metabolites synthesized by fungi.

\subsubsection{Process of Screening of Antifungal Metabolites from Endophytic Origin}

Microorganisms grown in the petri plates or culture broth constitute minimal growth medium needed for their survival. Any kind of stress or transfer of microorganisms on selective media acts as a stimulation for production of their secondary bioactive compounds. These secondary metabolites are produced for their survival in odd environments and strictly act as the selection force for the expression of their 
antimicrobial-producing genes. These crude by-products of microbial cultures are filtered and purified for their industrial, medicinal, and agricultural exploitation. Soil microorganisms have been exploited for a long time for production of antibiotics, but microorganisms inhabiting plants are a new source in that respect.

Plants are selected usually with potent medicinal applications. Here the knowledge of ethnobotany and folk taxonomy contributes a lot in this selection procedure. A strong literature survey supports the plant selection. The plants are surface sterilized and plated in nutrient-less solid plates. The fungi emerge out from different explants using the decaying plant parts as their primary growth substance. The isolates are identified by microscopic structures focusing on their conidial morphology, spore sculpturing, and colony characters. Confirmatory identification includes 18s rRNA analysis. Endophytic fungi are tested for their antifungal activity against phytopathogenic fungi by one-to-one inhibition assay or antagonistic test (Fig. 9.3). Two agar portions containing fungal hypha of endophyte and pathogen are placed on opposite sides of the plate. If the growth of pathogenic one is arrested partially or completely, that endophytic isolate is marked as antifungal agent and selected for further studies. Another way of screening includes separating the agar plate into two equal halves, and two fungi are placed on two separate sides of the discontinuous plate. This test aims to screen the endophytes that produce volatile antifungals. If the isolate is potent enough to produce volatile organic compounds with fungi static or cidal activity, this will cease the growth of the pathogenic strain. Then that isolate would be qualitatively and quantitatively measured for their volatile emissions using GC-MS as the master equipment (Fig. 9.4). Liquid extracts of endophytic fungi are also tested for antifungal potentials by agar well-diffusion method. The fungal extract having antibiotic property shows clear zone of inhibition of growth of the pathogenic fungus surrounding the area of application of that fungal liquid. The potent isolate will be mass cultured, and the bioactive molecules will be extracted using organic solvents like ethyl acetate, ethyl ether, and n-hexane. Steps include purification of that fungal extract by column chromatography, detection of the compound by thin-layer chromatography, and analysis of compounds by HPLC and mass chromatography. Field experiment includes the synergistic effect of a pure compound with mixture of natural compounds, and the effectivity of a newly applied antifungal agent strictly depends on the host plant and pathogenic microorganism's interaction, environmental condition, and development of drug resistance by that organism. Application of pellets soaked in fungal extracts also is a method of determination of antifungal activity.

\subsubsection{Diversity of Antifungal Metabolites}

Secondary metabolites are itself diverse in nature. A variety of bioactive secondary metabolites are produced at significant concentrations by the endophytic microbial flora. The major components include quinones, phenols, phenolic esters, steroids, terpenoids, cytochalasins, benzopyranone, alkaloids, isocoumarins, and chromones. 


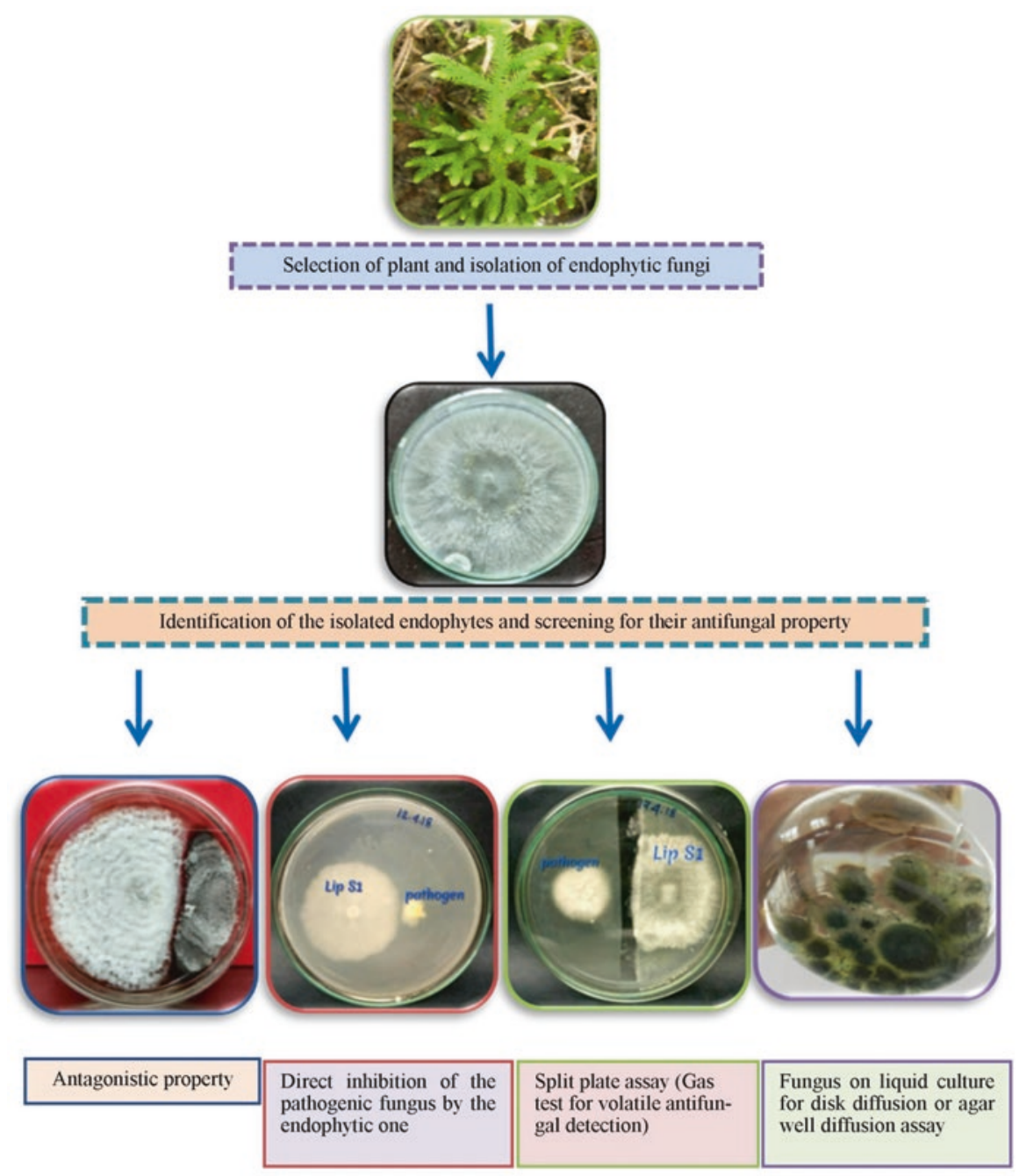

Fig. 9.3 Different approaches for the screening of endophytic fungi with antifungal activity

Till date, a large number of plants have been studied for their endophytic flora as antifungal agents (Table 9.3).

\subsubsection{Alkaloids}

Alkaloid was the first ever reported insecticidal bioactive product. Cryptocin was isolated from endophyte of Tripterygium wilfordii, a plant of Celastraceae family. The inner barks of the stem were used as explant, and Cryptosporiopsis cf. quercina was isolated as a potent endophyte active against Pyricularia oryzae and some other phytopathogenic fungi ( $\mathrm{Li}$ et al. 2000). Colletotrichum sp. produces 6-isoprenylindole-3-corboxylic acid having inhibitory action against Phytophthora 
Confirmation by olfactory test by different persons Or Inhibition of pathogenic fungal growth in split plate method.

Direct extraction of the volatile emission by SPME fiber from the petri plate Or Growth of the selected fungus on GC-vials

Detection by SPME method or head space technique using GC-MS as the tool

Detection of volatiles by proper method and generation of complete chromatogram and report development by the help of NIST library
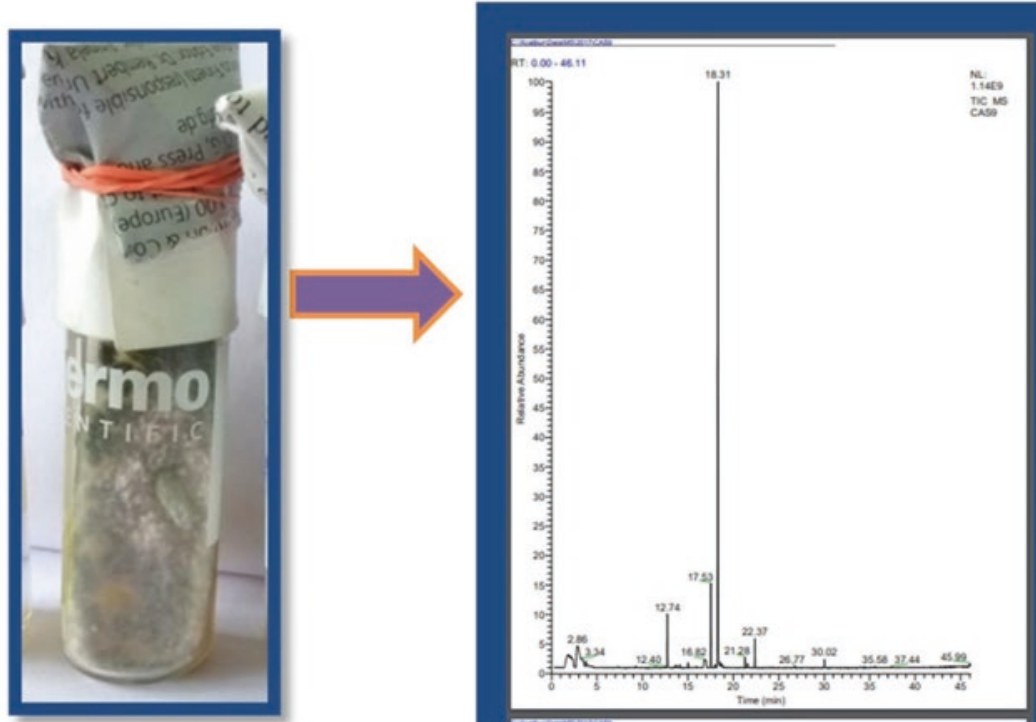

Fig. 9.4 Detection of volatile organic compounds of endophytic origin

capsici, a pathogen of Cucurbitaceae, Fabaceae, and Solanaceae, and also other phytopathogens Rhizoctonia cerealis and Gaeumannomyces graminis var. tritici, a common pathogen of Poaceae family ( $\mathrm{Lu}$ et al. 2000). Epoxycytochalasin $\mathrm{H}$ and cytochalasins $\mathrm{N}$ and $\mathrm{H}$ were isolated as chloroform and methanolic extracts of 
Table 9.3 Antifungal activity of endophytic fungi

\begin{tabular}{|c|c|c|c|}
\hline $\begin{array}{l}\text { Name of the endophytic } \\
\text { isolate }\end{array}$ & Source plant & Antifungal against & References \\
\hline $\begin{array}{l}\text { Ovulariopsis sp. and } \\
\text { Alternaria sp. }\end{array}$ & $\begin{array}{l}\text { Datura } \\
\text { stramonium }\end{array}$ & $\begin{array}{l}\text { Aspergillus niger, } \\
\text { Colletotrichum } \\
\text { gloeosporioides, } \\
\text { Fusarium sp., } \\
\text { Phytophthora } \\
\text { nicotianae, } \\
\text { Scopulariopsis sp., } \\
\text { Trichoderma viride, } \\
\text { Verticillium } \text { sp. }\end{array}$ & $\begin{array}{l}\text { Li et al. }(2005 a, \\
\text { b) }\end{array}$ \\
\hline $\begin{array}{l}\text { Beauveria bassiana, } \\
\text { Trichoderma koningii, } \\
\text { Alternaria alternata, } \\
\text { Phoma sp., } \\
\text { Acremonium strictum }\end{array}$ & $\begin{array}{l}\text { Zea mays } \\
\text { (maize) (roots) }\end{array}$ & $\begin{array}{l}\text { Fusarium oxysporum, } \\
\text { Fusarium } \\
\text { pallidoroseum, } \\
\text { Fusarium } \\
\text { verticillioides, } \\
\text { Cladosporium } \\
\text { herbarum }\end{array}$ & $\begin{array}{l}\text { Orole and } \\
\text { Adejumo (2009) }\end{array}$ \\
\hline $\begin{array}{l}\text { Alternaria sp., Chaetomium } \\
\text { sp., Dothideomycetes sp., } \\
\text { Thielavia subthermophila }\end{array}$ & $\begin{array}{l}\text { Tylophora } \\
\text { indica }\end{array}$ & $\begin{array}{l}\text { Sclerotinia } \\
\text { sclerotiorum, Fusarium } \\
\text { oxysporum, Fusarium } \\
\text { oxysporum }\end{array}$ & $\begin{array}{l}\text { Kumar et al. } \\
\text { (2011) }\end{array}$ \\
\hline Chaetomium globosum & $\begin{array}{l}\text { Withania } \\
\text { somnifera }\end{array}$ & S. sclerotiorum & $\begin{array}{l}\text { Kumar et al. } \\
\text { (2013) }\end{array}$ \\
\hline $\begin{array}{l}\text { Nigrospora oryzae, } \\
\text { Fusarium proliferatum, } \\
\text { Guignardia cammillae, } \\
\text { Alternaria destruens, } \\
\text { Chaetomium sp. }\end{array}$ & Jatropha curcas & S. sclerotiorum & $\begin{array}{l}\text { Kumar and } \\
\text { Kaushik(2013) }\end{array}$ \\
\hline $\begin{array}{l}\text { Phytophthora infestans, } \\
\text { Fusarium oxysporum }\end{array}$ & Triticum durum & $\begin{array}{l}\text { Alternaria sp., } \\
\text { Cladosporium sp., } \\
\text { Penicillium } \mathrm{sp} ., \\
\text { Aspergillus sp., } \\
\text { Chaetomium sp., } \\
\text { Phoma sp. }\end{array}$ & $\begin{array}{l}\text { Sadrati et al. } \\
\text { (2013) }\end{array}$ \\
\hline $\begin{array}{l}\text { Cladosporium sp., } \\
\text { Curvularia sp., Penicillium } \\
\text { sp. }\end{array}$ & $\begin{array}{l}\text { Moso bamboo } \\
\text { (Phyllostachys } \\
\text { edulis) (seeds) }\end{array}$ & $\begin{array}{l}\text { Curvularia eragrostidis, } \\
\text { Pleospora herbarum, } \\
\text { Arthrinium sacchari, } \\
\text { Arthrinium } \\
\text { phaeospermum }\end{array}$ & $\begin{array}{l}\text { Shen et al. } \\
\text { (2014) }\end{array}$ \\
\hline Trichothecium sp. & $\begin{array}{l}\text { Phyllanthus } \\
\text { amarus }\end{array}$ & $\begin{array}{l}\text { Penicillium expansum } \\
\text { (blue mold of apples) }\end{array}$ & $\begin{array}{l}\text { Taware et al. } \\
\text { (2014) }\end{array}$ \\
\hline $\begin{array}{l}\text { Alternaria sp., Biscogniauxia } \\
\text { mediterranea, Cladosporium } \\
\text { funiculosum, } \\
\text { Paraconiothyrium sp. }\end{array}$ & $\begin{array}{l}\text { Opuntia } \\
\text { humifusa }\end{array}$ & $\begin{array}{l}\text { Colletotrichum } \\
\text { fragariae, } C . \\
\text { gloeosporioides, } C . \\
\text { acutatum }\end{array}$ & $\begin{array}{l}\text { Silva-Hughesa } \\
\text { et al. (2015) }\end{array}$ \\
\hline $\begin{array}{l}\text { Rhexocercosporidium sp., } F \text {. } \\
\text { solani }\end{array}$ & $\begin{array}{l}\text { Sophora } \\
\text { tonkinensis } \\
\text { Gapnep }\end{array}$ & $\begin{array}{l}\text { Alternaria panax, } F . \\
\text { solani, } C \text {. } \\
\text { gloeosporioides }\end{array}$ & Yao et al. (2017) \\
\hline
\end{tabular}


Table 9.3 (continued)

\begin{tabular}{|c|c|c|c|}
\hline $\begin{array}{l}\text { Name of the endophytic } \\
\text { isolate }\end{array}$ & Source plant & Antifungal against & References \\
\hline $\begin{array}{l}\text { Glomerella cingulate, } \\
\text { Colletotrichum } \\
\text { gloeosporioides, C. } \\
\text { truncatum, Lasiodiplodia } \\
\text { pseudotheobromae, } \\
\text { Dothideomycetes sp. }\end{array}$ & $\begin{array}{l}\text { Houttuynia } \\
\text { cordata Thunb. }\end{array}$ & $\begin{array}{l}\text { F. oxysporum, S. rolfsii, } \\
\text { T. harzianum, } \\
\text { Rhizoctonia sp., A. } \\
\text { brassicicola, } \\
\text { P. palmivora }\end{array}$ & $\begin{array}{l}\text { Aramsirirujiwet } \\
\text { et al. (2016) }\end{array}$ \\
\hline $\begin{array}{l}\text { C. boninense, } F \text {. } \\
\text { chlamydosporum, } \\
\text { C. aeria, M. yucatanensis, } \\
\text { Cladosporium sp. }\end{array}$ & $\begin{array}{l}\text { Monarda } \\
\text { citriodora (leaf, } \\
\text { roots, and } \\
\text { flowers) }\end{array}$ & $\begin{array}{l}\text { F. solani, Sclerotinia } \\
\text { sp., Colletotrichum } \\
\text { capsici, A. flavus, } A . \\
\text { fumigatus }\end{array}$ & $\begin{array}{l}\text { Katoch and Pull } \\
\text { (2017) }\end{array}$ \\
\hline $\begin{array}{l}\text { Trichoderma } \\
\text { longibrachiatum strain } \\
\text { BHU-BOT-RYRL17, } \\
\text { Syncephalastrum racemosum } \\
\text { strain AQGSS 12, } \\
\text { Trichoderma } \\
\text { longibrachiatum voucher } 50\end{array}$ & $\begin{array}{l}\text { Markhamia } \\
\text { tomentosa }\end{array}$ & $\begin{array}{l}\text { Fusarium oxysporum, } \\
\text { Sclerotinia } \\
\text { sclerotiorum, } \\
\text { Rhizoctonia solani, } \\
\text { Botrytis cinerea }\end{array}$ & $\begin{array}{l}\text { Ibrahima et al. } \\
\text { (2017) }\end{array}$ \\
\hline $\begin{array}{l}\text { Penicillium simplicissimum, } \\
\text { Leptosphaeria sp., } \\
\text { Talaromyces flavus, } \\
\text { Acremonium sp. }\end{array}$ & $\begin{array}{l}\text { Cotton roots } \\
\text { (Gossypium } \\
\text { hirsutum) }\end{array}$ & $\begin{array}{l}\text { V. dahlia (Verticillium } \\
\text { wilt disease) }\end{array}$ & $\begin{array}{l}\text { Yuan et al. } \\
\text { (2017) }\end{array}$ \\
\hline $\begin{array}{l}\text { Aspergillus sp., Xylaria sp., } \\
\text { Fusarium sp., Trichothecium } \\
\text { sp., Oidium sp. }\end{array}$ & $\begin{array}{l}\text { Camellia } \\
\text { oleifera }\end{array}$ & $\begin{array}{l}\text { Camellia oleifera } \\
\text { anthracnose pathogen }\end{array}$ & Yu et al. (2018) \\
\hline $\begin{array}{l}\text { Penicillium sp. (ARDS-2.3), } \\
\text { Aspergillus oryzae } \\
\text { (ARHS-1.1) }\end{array}$ & $\begin{array}{l}\text { Asparagus } \\
\text { racemosus Willd }\end{array}$ & $\begin{array}{l}\text { Botrytis cinerea (gray } \\
\text { mold), Sclerotinia } \\
\text { sclerotiorum (stem rot), } \\
\text { Rhizoctonia solani (root } \\
\text { rot), Fusarium } \\
\text { oxysporum (wilt) }\end{array}$ & $\begin{array}{l}\text { Chowdhary and } \\
\text { Kaushik (2018) }\end{array}$ \\
\hline $\begin{array}{l}\text { Aspergillus sp., Curvularia } \\
\text { sp., Fusarium oxysporum }\end{array}$ & $\begin{array}{l}\text { Dendrobium } \\
\text { lindleyi }\end{array}$ & $\begin{array}{l}\text { Fusarium sp., } \\
\text { Sclerotium sp., } \\
\text { Colletotrichum sp., } \\
\text { Curvularia } \text { sp., } \\
\text { Phytophthora sp. }\end{array}$ & $\begin{array}{l}\text { Bungtongdee } \\
\text { (2019) }\end{array}$ \\
\hline
\end{tabular}

Phomopsis sp., an endophyte of Gossypium hirsutum. It showed potent antifungal activity against species of Bipolaris (B. sorokiniana, B. maydi), Botrytis (B. cinerea), Sclerotinia (Sclerotinia sclerotiorum), Rhizoctonia (R. cerealis), and Fusarium (Fusarium oxysporum) (Fu et al. 2011). A lot of endophytes have been explored for their antifungal production, but only a few of them were positive for antifungal metabolites categorizing in alkaloids. The common alkaloids acting as the antifungal agents of endophytic fungal origin are gliotoxin, cryptocanadin, tyrocidine A, fumigaclavine C, fumitremorgin C, 1-N-methyl albonoursin, and phomapsichalasin. 


\subsubsection{Terpene Derivatives}

The terpenoids, usually called isoprenoids, are large and diverse group of naturally occurring organic compounds derived from terpenes that are multicyclic. Sixty percent of all the known natural products are terpenoids in nature. Some endophytic fungicidal products are of terpenes by their native chemical structure. Endophytic isolates (Hormonema sp.) of gymnospermous plant Juniperus communis were reported to be antifungal producers of a triterpene glycoside enfumafungin (Pelaez et al. 2000). Known antifungal sterols of endophytic origin are $3 \beta$-hydroxyergosta-5-ene, 3-oxoergosta-4,6,8,22-tetraene, etc. The sterols are strong inhibitors of Helminthosporium sativum (present name: Bipolaris sorokiniana), the asexual stage of Cochliobolus sativus, a common root rot pathogen of wheat and barley crops which also infects leaf and stems of Poaceae plants (Lu et al. 2000). Sesquiterpenes are reported to be the growth inhibitors of Cladosporium phlei (causal organism of leaf spot disease of timothy grass, Phleum pratense). This is a unique example where the host plant (Phleum pratense) itself harbors the endophyte (Epichloe typhina) that inhibits the growth of its leaf spot pathogen (Cladosporium phlei).

\subsubsection{Isocoumarins}

From the point of view of organic chemistry, isocoumarins are defined as the isomer of coumarin where the orientation of the lactone is reversely arranged. Zhang and his coworkers in the year 2008 isolated an endophytic fungus named Microdochium bolleyi from Fagonia cretica (also known as virgin's mantle of Zygophyllaceae family), a herb of semiarid regions of Gomera. Isocoumarins were identified as the active compounds having antifungal activity against Microbotryum violaceum (previously known as Ustilago violacea), an obligate parasite of Basidiomycete group and a common infectant of members of Caryophyllaceae causing smut of anther. The four isolated and identified isocoumarins are monocerin, 12-oxo epimers of monocerin, and open-ring derivative compounds of monocerin. The compounds are obtained as mixtures by column chromatography followed by Sephadex LH-20 chromatography techniques. Preparative TLC further differentiated the four compounds. Monocerin and its analogues were previously reported as antifungal compounds from fungal sources of Drechslera monoceras, Exserohilum monoceras, Helminthosporium monoceras, Exserohilum turcum, and Fusarium larvarum (Aldridge and Turner 1970; Robeson and Strobel 1982; Grove and Pople 1979; Claydon et al. 1979). These secondary metabolites act on pathogens by interfering stages of divisional phases of cell cycle. The second isocoumarin was colorless oil. The third and fourth one are represented by the empirical formula of $\mathrm{C}_{16} \mathrm{H}_{20} \mathrm{O}_{7}$ and $\mathrm{C}_{16} \mathrm{H}_{22} \mathrm{O}_{7}$. The fourth one is structurally correlated to fusarentin 6,7-dimethyl ether. Both the compounds are of heptaketide in their origin, and it is revealed that fusarentins are the probable precursors of the active compounds monocerins (Scott et al. 1984; Axford et al. 2004). Dihydroisocoumarins, mellein (an isocoumarin derivative), (R)-7-hydroxymellein, and fonsecinone were reported from species of Xylaria (endophyte of Piper aduncum), Pezicula, Penicillium (Alibertia macrophylla), and 
Aspergillus (Cynodon dactylon), respectively (Oliveira et al. 2011; Schulz et al. 1995; Song et al. 2004).

\subsubsection{Phenolics as the Most Potent Antifungal from Endophytic Source}

Phenols (popularly known as phenolics) represent a class of chemical compounds characterized with a hydroxyl group attached to an aromatic hydrocarbon group. Phenol (or carbolic acid) is a colorless crystalline solid, aromatic compound having benzene rings. They are predominantly found in the plant kingdom as a response to stress and are of utmost importance. Endophytic culture extracts are also known to be rich sources of phenolics; usually they are directly proportional to the antioxidative property of any fungal isolate, but in some particular cases, they are characterized with their antifungal potentials against phytopathogenic fungus. Usually the liquid culture extracts of the endophytic isolates are subjected to solvent extraction using ethyl acetate, n-hexane, ethyl ether, etc. Those organic solvents are believed to extract the phenolics from the water-based culture broth. Those extracted compounds are further screened for their antifungal efficiency. Ethyl acetate extracts of endophytic Phoma sp. are reported to contain tetralone metabolites (derivatives of $\alpha$-tetralone, 3,6,7-trihydroxy- $\alpha$-tetralone) inhibiting the growth of two common broad phytopathogenic fungus Fusarium oxysporum and Rhizoctonia solani. Griseofulvin is known to be the first antifungal compound isolated from Penicillium griseofulvum. Later it is isolated from several species of fungi including endophytic Penicillium canescens and Xylaria sp. (member of Xylariaceae family). Griseofulvin from endophytic $P$. canescens of popular Chinese medicinal plant Polygonatum cyrtonema (Polygonaceae) showed strong inhibitory effectivity against phytopathogenic Botrytis cinerea, Sclerotinia sclerotiorum, Colletotrichum orbiculare, and Didymella bryoniae (Wang et al. 2010). Other than Penicillium, endophytic Xylaria sp. isolated as an endophyte of Abies holophylla yields griseofulvin and dechlorogriseofulvin for in vitro and in vivo effectivity against pathogenic Magnaporthe grisea, Corticium sasakii, Blumeria graminis (Park et al. 2005). The ascomycete fungus Pestalotiopsis is known to be a common plant pathogen but also has been reported many times because of their endophytic existence in the host plants. The two common species Pestalotiopsis microspora (host: tropical plant Terminalia morobensis) and P. fici are reported to be producing antifungal metabolites isopestacin and pestalofones D-E (Harper et al. 2003; Liu et al. 2009a, b). Chlorogenic acid and colletotric acids are antifungal phenolics of Colletotrichum gloeosporioides and Sordariomycetes sp., respectively (Chen et al. 2010; Zou et al. 2000). They were isolated from medicinal plants of China (Artemisia mongolica and Eucommia ulmoides) and effective against fungi imperfecti Helminthosporium sativum. Orcinol is used for the production of a dye called orcein used randomly for the staining of cells and chromosomes. Orcinol is popularly known for its antifungal activity too and has been isolated as a product of endophytic origin of Penicillium sp. from Alibertia macrophylla (a plant of Rubiaceae) showing bioactivity against Cladosporium cladosporioides and Cladosporium sphaerospermum (Oliveira et al. 2014). Endophytic Phomopsis sp., Dothiorella sp., and Diaporthe sp. have also 
been tested for their antifungal production and antifungal compounds that were detected (Brady et al. 2000; Xu et al. 2004; Huang et al. 2008).

\subsubsection{Volatile Organic Compounds}

Volatile organic compounds (VOCs) are said to be a type of organic low-molecularweight carbon-containing small compounds (up to $\mathrm{C} 20$ ) that have a high vapor pressure with low molecular mass (100-500 daltons) at room temperature. The high vapor pressure results from a low boiling point of that chemical compound, which causes a huge quantity of molecules to evaporate from the liquid, solid, or semisolid form of the compound and gets released into the surrounding environment. The endophytes are unique in their volatile emissions. The term mycofumigation that is very much popular with the treatment of agricultural phytopathogens is actually the output of VOCs that originated from endophytic isolates. The first ever reported volatile antibiotic producer was Muscodor albus (Xylariaceae family), an endophyte of Guazuma ulmifolia (a plant of Sterculiaceae family collected from tropical forest of SW Ecuador), isolated by Gary Strobel and his co-workers (Strobel et al. 2007). The major compounds isolated by GCMS are known to be involved in antifungal, antibacterial activity. Compounds include butanoic acid, 2-methyl-; butanoic acid, 3-methyl-; 2-butenal, 2-methyl-; butanoic acid, 3-methylbutyl ester; 3-buten-1-ol, 3-methyl; guaiol; 1-octene, 3-ethyl-; formamide, N-(1-methylpropyl); azulene and naphthalene derivatives; caryophyllene; phenylethyl alcohol; acetic acid, 2-phenylethyl ester; bulnesene; and various propanoic acid, 2-methyl- derivatives. These compounds were tested against a number of phytopathogenic fungi (Botrytis cinerea, Mycosphaerella fijiensis, Pythium ultimum, Phytophthora cinnamomi) showing partial or complete death or growth inhibition of those pathogens after 2 or 4 days of incubation. Muscodor albus was reported from a diverse type of host plants, i.e., Myristica fragrans, Terminalia prostrata, Cinnamomum zeylanicum, and Ginkgo biloba, by several workers (Worapong et al. 2001; Sopalun et al. 2003; Ezra and Strobel 2003; Mercier et al. 2004; Ezra et al. 2004a, b; Atmosukarto et al. 2005; Lacey and Naven 2006; Lacey et al. 2009; Strobel et al. 2007; Banerjee et al. 2010a, b; Corcuff et al. 2011; Alpha et al. 2015). The mycofumigants are effective against pathogen Fusarium culmorum, causal agent of seedling blight, foot rot, ear blight, stalk rot, and common rot of cereals. Sexual stage (teleomorph) of Glomerella cingulata, a fungus of Glomerellaceae, is a potent pathogen causing anthracnose-like symptoms of water-soaked, sunken spots and necrotic lesions on fruits of forest trees. This phytopathogen is strictly inhibited by the volatile emissions of this novel endophyte. Banerjee et al. (2010a, b) first reported Muscodor albus strain GBA from the USA as an isolate of Ginkgo biloba (first isolate of M. albus from G. biloba) and tested the biological efficacy of its volatile mixtures against agricultural pathogens and also evaluated its promises to be used as a commercial mycofumigant agent for controlling the fungal diseases in storage fruits and vegetables, that is, agricultural productions and during food transportation. The strain GBA in comparison to other strains of Muscodor E6 and CZ620 completely 
inhibits and potentially kills the member of Phycomycetes, Pythium ultimum after 2 days of exposure of the mixture of volatiles. The organic compounds include alcohols, acids, esters, ketones, and lipids as their active components. 1-butanol, 3-methyl-, acetate was found in significant quantities. Vitrine, a terpenoid, was first isolated from Muscodor albus strain GAB. The volatile mixture is artificially produced by the mixture of the pure compounds, and that mixture is again checked for antifungal activity. A positive mycocidal or mycostatic effect similar to the effect of endophyte's volatile emission will confirm establishment of the endophyte and its mixture as the biocontrol or antifungal agent. Myrothecium inundatum, an endophyte of herbaceous Acalypha indica (Euphorbiacea member collected from northeastern part of India), produces unique mixture of volatile components having 3-octanone, 3-octanol, 7-octen-4-ol, sesquiterpenes, organic acids, methyl esters, naphthalene, 2-octanoic acid, heptanoic acid, etc. This endophyte produces foam in its liquid culture predominant with long-chain carbon compounds like octane, 1,4-cyclohexadiene, 1-methyl- and cyclohexane, and 1-ethylpropyl. The presence of this type of compounds emphasizes the concept of "mycodiesel" Several other species of Muscodor, for example, Muscodor heveae, Muscodor ghoomensis, M. indica, M. camphora, M. suthepensis, Muscodor tigerii, Muscodor darjeelingensis, Muscodor strobelii, Muscodor kashayum, Muscodor musae, Muscodor sutura, Muscodor cinnamomi, Muscodor crispans, Muscodor vitigenus, and M. roseus, were isolated from different parts of the world and from various types of hosts, for example, Hevea brasiliensis, Cinnamomum camphora, Cinnamomum bejolghota, C. zeylanicum, Aegle marmelos, Musa acuminate, Prestonia trifidi, Grevillea pteridifolia, Erythrophleum chlorostachys, Paullinia paullinioides, and Hevea brasiliensis (Meshram et al. 2013, 2015, 2017; Suwannarach et al. 2015; Saxena et al. 2015; Suwannarach et al. 2010, 2012, 2013; Kudalkar et al. 2012; Mitchell et al. 2010; Worapong et al. 2002; Daisy et al. 2002; Siri-udom et al. 2016), showing antifungal activity against a large number of phytopathogens including A. fumigatus, Botrytis cinerea, Colletotrichum lagenarium, Ceratocystis ulmi, Cercospora beticola, Geotrichum candidum, Mycosphaerella fijiensis, Phytophthora cinnamomi, Phytophthora palmivora, Pythium ultimum, Rhizoctonia solani, Sclerotinia sclerotiorum, and Verticillium dahlia.

\subsubsection{VOC Producers as the Postharvest Biocontrol Agents and Mycofumigants}

Postharvest fungal disease is one of the prime causes of agricultural loss of crops. Use of biological agent to minimize this loss is one of the vital targets of agriculturalists, horticulturalists, and plant biologists. Several chemical agents have been already tested for practical applications, but endophytes are less explored organisms in this arena. Volatiles from endophytic source open up new scope of utilization of unique mixtures of chemicals to be used as mycofumigant agents. A large number of endophytes have already been screened for their postharvest disease management ability (Table 9.4). The volatiles of the endophyte could be considered as the natural fungicides. Muscodor vitigenus, an endophyte of Hevea brasiliensis, was analyzed in GC-MS for their volatile production. The isolates produce a unique mixture of 


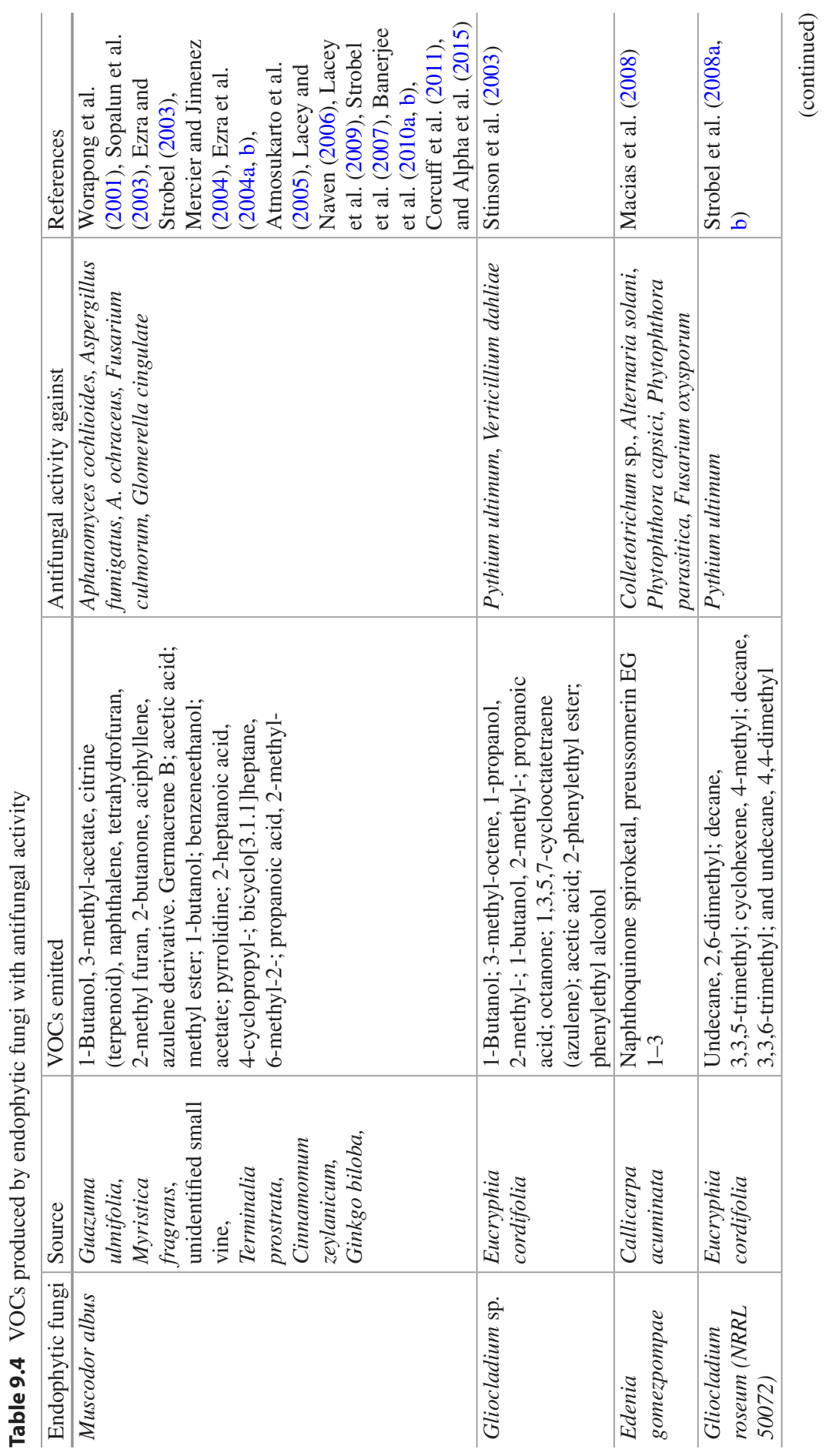




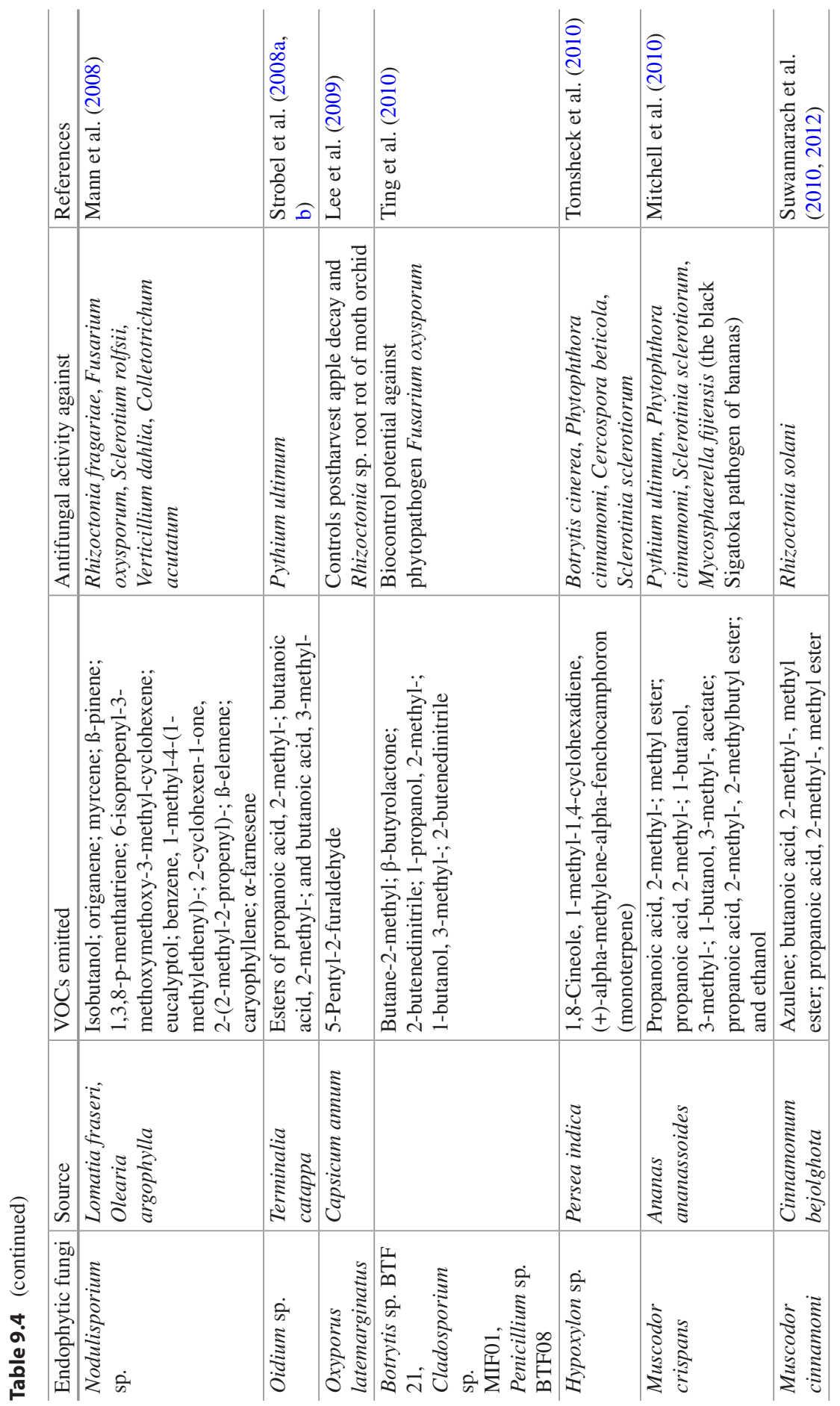




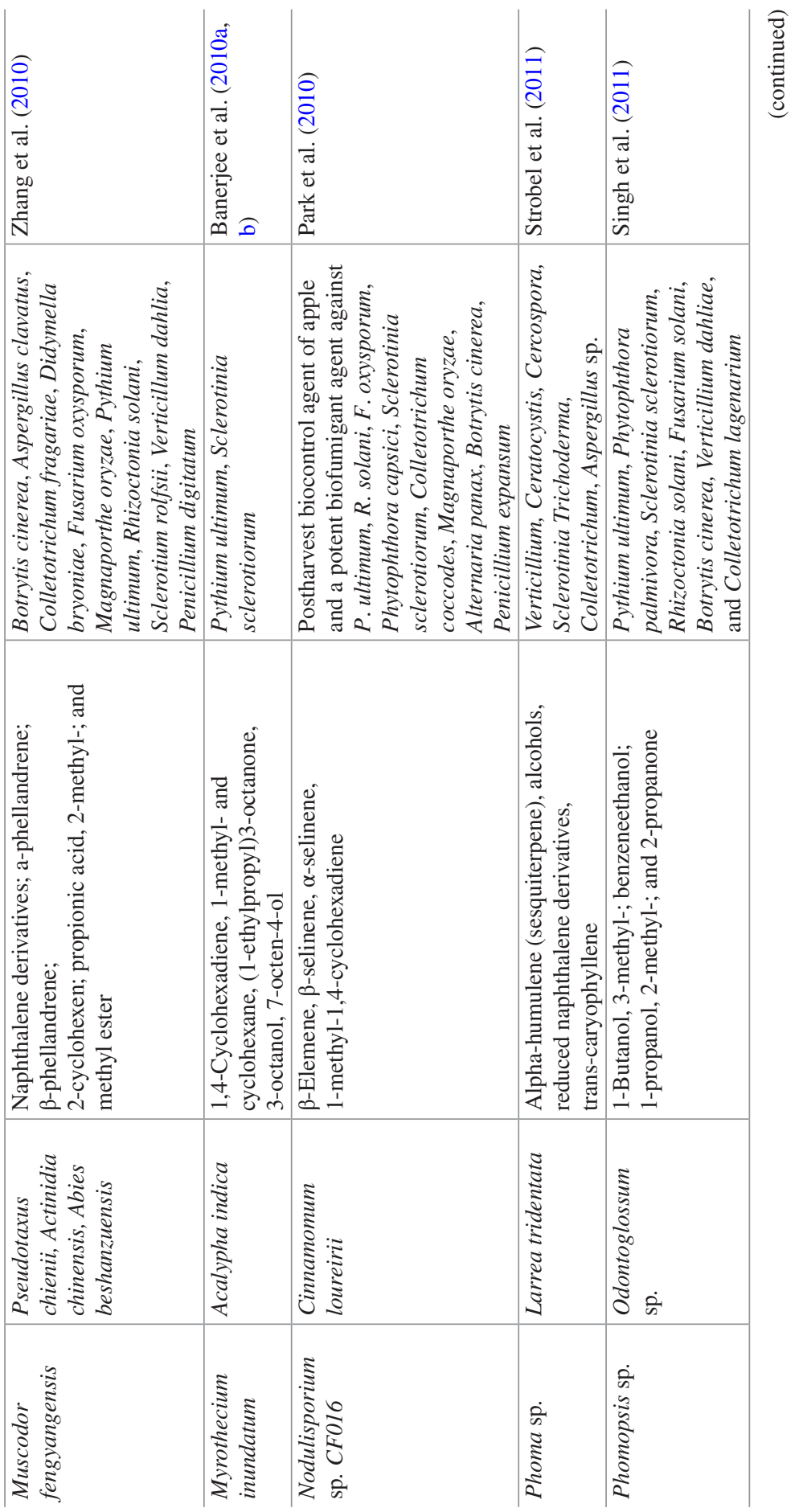




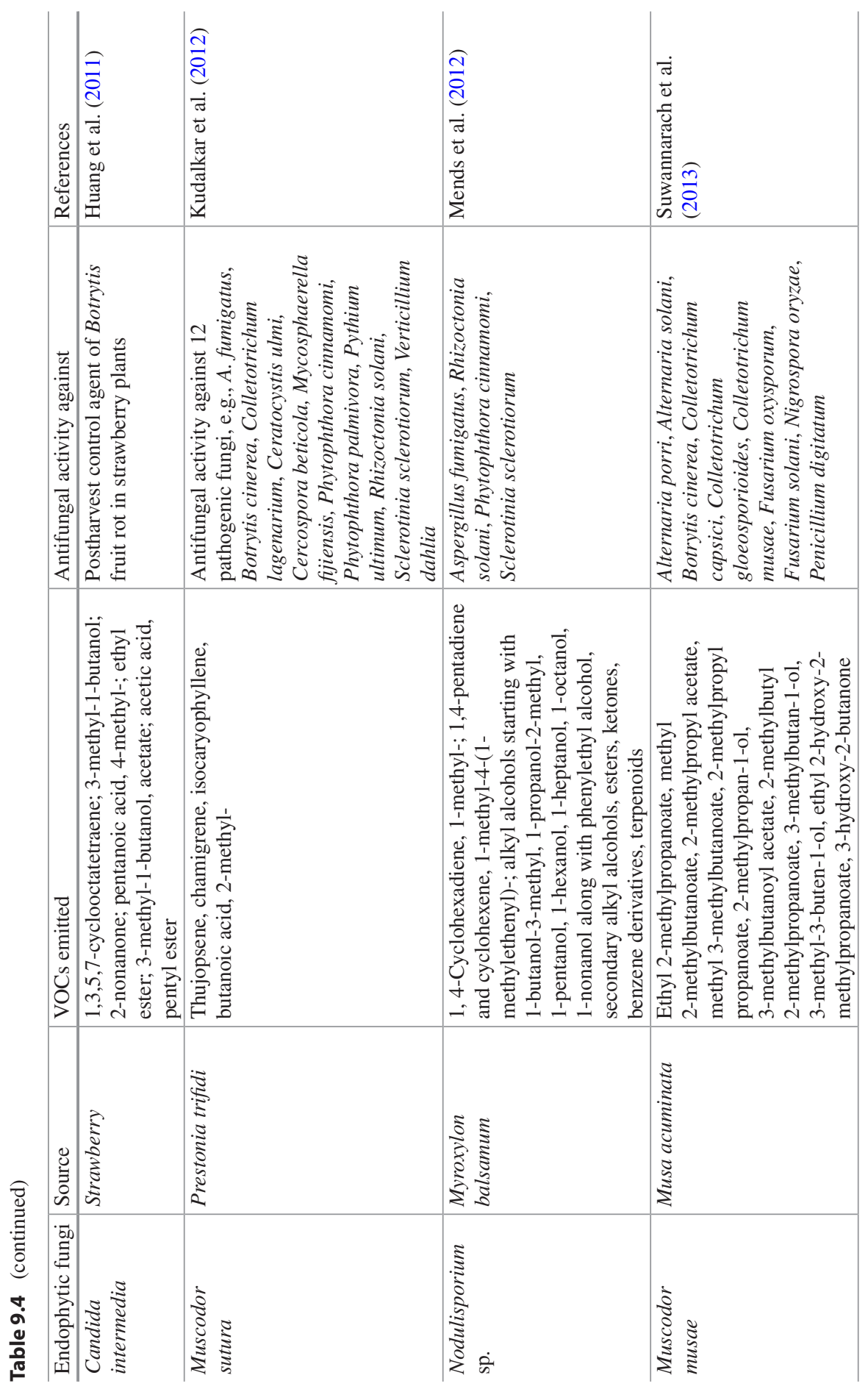




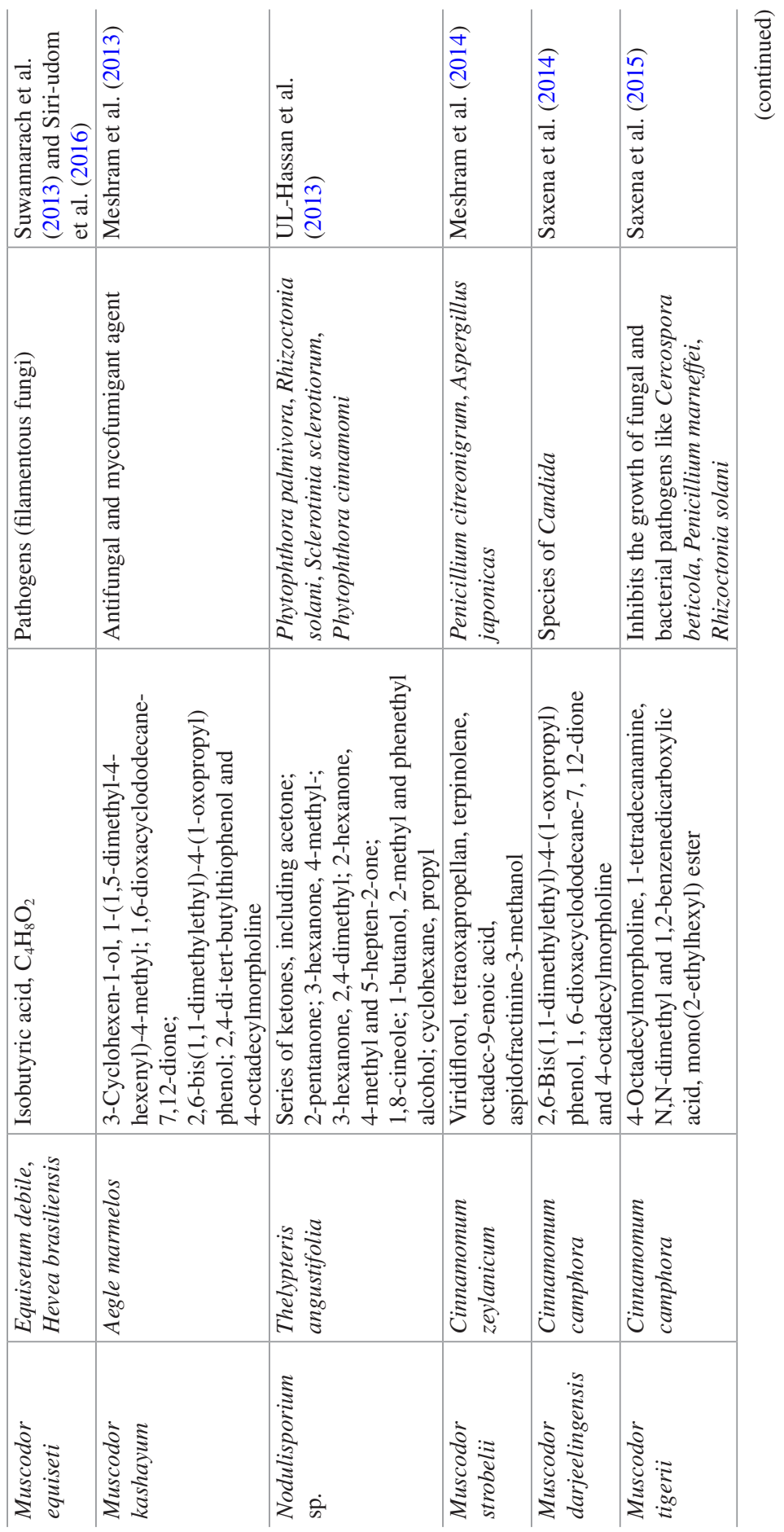




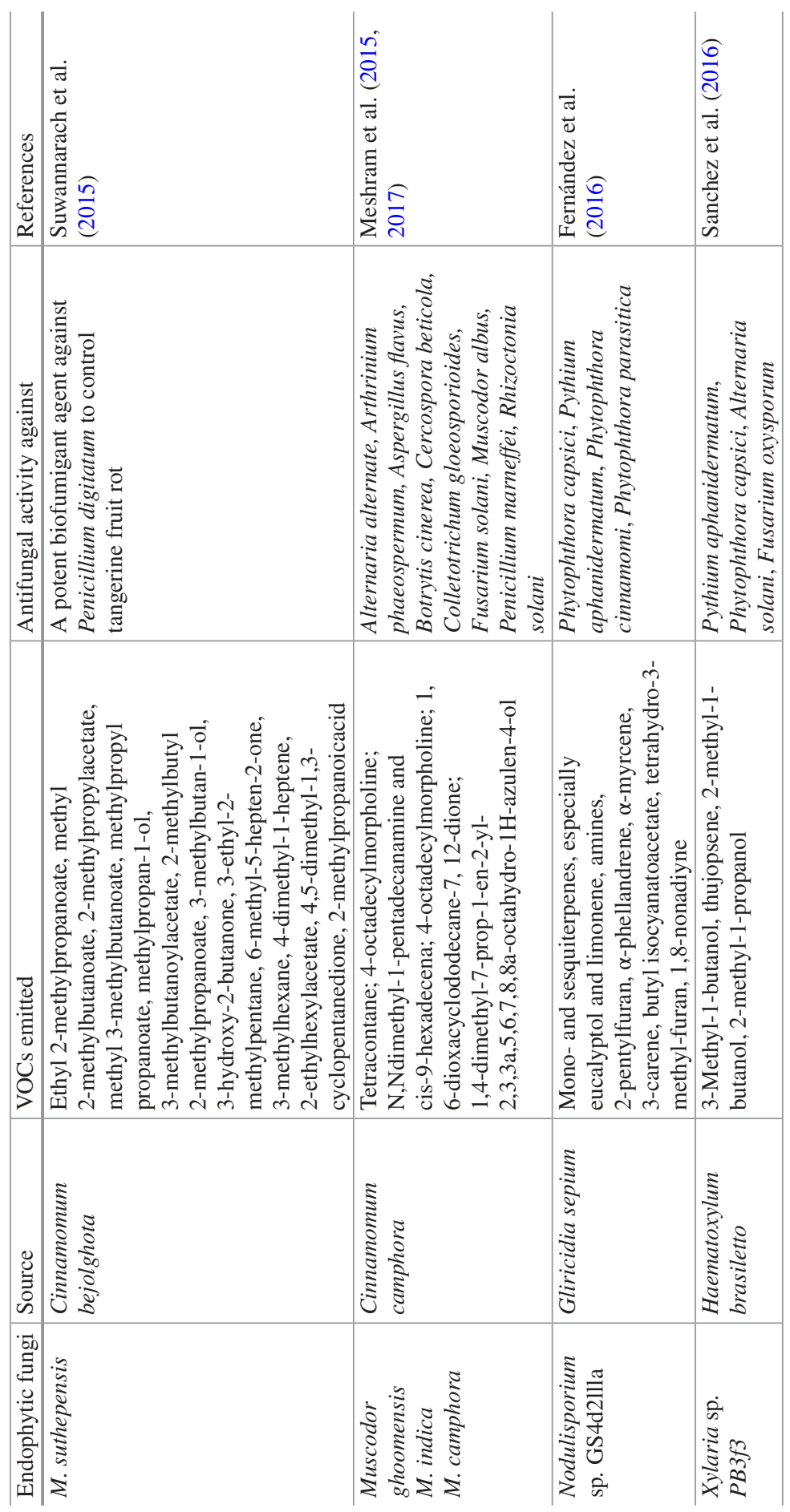




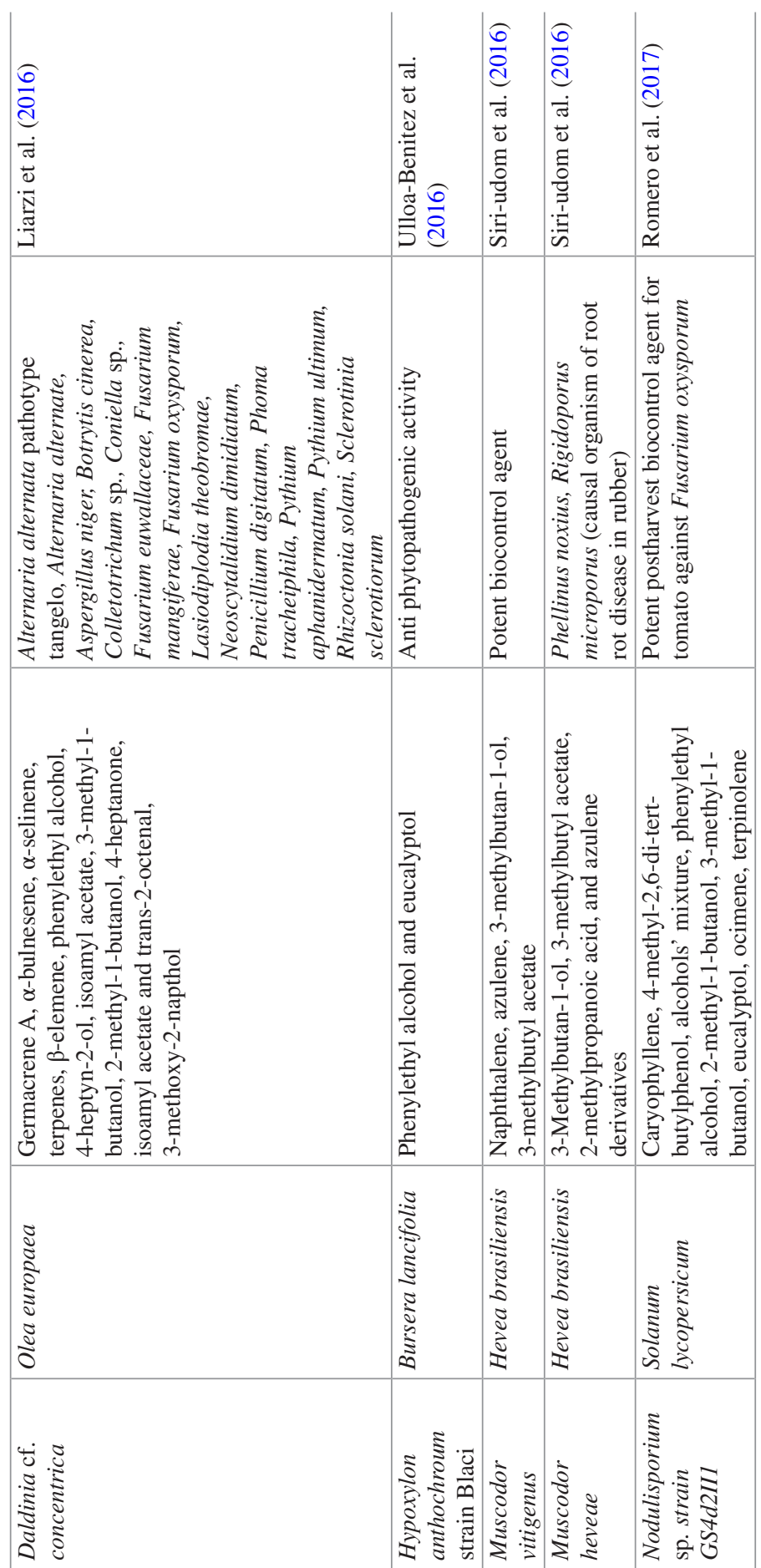


naphthalene, azulene, 3-methylbutan-1-ol, and 3-methylbutyl acetate that partially or completely inhibits the growth of the phytopathogenic fungal species. Colletotrichum gloeosporioides, a commercially significant plant pathogen, usually acts as a secondary invader of injured tissue or saprophyte and causes bitter root in variety of crops; tropical fruits like yams, papaya, avocado, coffee, sweet pepper, tomato; and also perennial grasses. Rhizoctonia solani, a commercially significant plant pathogen of Basidiomycotina, causes symptoms of brown patch on turf grass, damping off of soybean seedlings, black scurf of potatoes, root rot of sugar beet, belly rot of cucumber, sheath blight of rice, etc. Another phytopathogen named Fusarium oxysporum, the causal agent of Fusarium wilt or koa wilt, and Rigidoporus microporus, the causal agent of white root rot disease on tropical crops like cacao, were suppressed in terms of their growth upon exposure to the volatiles of $M$. vitigenus. Phytophthora parasitica (oomycetous fungi) causes destructive diseases of a wide range of crop plants (Arabidopsis thaliana and Medicago truncatula, the two guinea pigs of plant science), nursery and ornamental plants, and forest ecosystems. Another phytopathogenic species of Ganoderma austral that forms white heart rot in Tilia trees, Quercus sp. (oaks), Fagus sp. (beech), and Betula sp. (birch) is found to be inactive when exposed to the volatiles. Phellinus noxius is reported to be a serious threat to almost 200 plants covering 59 families of tropical forests of Asia, Africa, Japan, Taiwan, and the Pacific Islands, which is inhibited significantly by $M$. vitigenus volatiles. So $M$. vitigenus opens up scope for the biocontrol of all these seven harmful phytopathogens and ensures the complete protection of host from fungal attack. This could be concluded as natural fungicides. So mycofumigation by these volatiles could minimize the loss caused by these pathogens. Stinson and his co-workers (2003) isolated endophytic Gliocladium sp. (Hypocreaceae) from Eucryphia cordifolia and reported multiple number of volatile compounds, for example, 1-butanol, 3 methyl; octene; 1-propanol, 2-methyl-; 1-butanol, 2-methyl-; propanoic acid; octanone; 1,3,5,7-cyclooctatetraene (azulene); acetic acid; 2-phenylethyl ester; and phenylethyl alcohol. These volatiles are lethal to major phytopathogens, for example, Pythium ultimum and Verticillium dahliae. Pythium ultimum is known to infect plants causing damping off and root rot disease of corn, soybean, potato, and wheat. Verticillium dahlia causes Verticillium wilt resulting in curled and discolored appearance of leaves of almost 350 species of eudicots of temperate regions. So using Gliocladium sp. as a biocontrol agent in tropics may reduce the agricultural loss to some extent. Edenia gomezpompae, a member of Pleosporaceae isolated as an endophyte of Callicarpa acuminata, was reported to produce naphthoquinone spiroketal showing antifungal activity against Colletotrichum sp., Alternaria solani, and Phytophthora capsici (Macias et al. 2008). Lee et al. (2009) performed mycofumigation with Oxyporus latemarginatus EF069 volatiles for control of postharvest apple (Malus pumila) decay and Rhizoctonia root rot infection on moth orchid (Phalaenopsis sp.). Apple is an important economic fruit, and biocontrol of apple fungal pathogens by volatile emissions of endophytic fungi is completely an innovative way of treatment. Suwannarach and his coworkers in the year 2010 isolated a new species of Muscodor, Muscodor cinnamomi CMU-Cib 461, from a member of Lauraceae named 
Cinnamomum bejolghota. This isolate was known to produce azulene, a new compound detected first from any Muscodor species. This species was tested in vitro and in vivo for antifungal activity against a common worldwide devastating pathogen Rhizoctonia solani (causal agent of damping off). The VOCs produced by this fungi include (S)-(+)-5-methyl-1-heptanol; ethyl acetate; propanoic acid, 2-methyl-, methyl ester; cis-2,4-dimethylthiane; S,S-dioxide; cyclopentane; butanoic acid, 2-methyl-, methyl ester; 1-butanol, 3-methyl-, acetate; $\beta$-humulene; azulene,

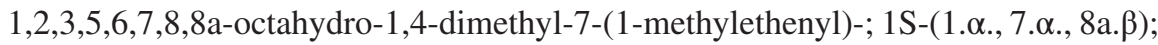
and eudosma-4(14),11-diene 1,1,1,5,7,7,7-heptamethyl-3,3-bis(trimethylsiloxy) tetrasiloxane. Rhizoctonia solani-infected seedlings were treated with volatile mixtures to assess the mycofumigation property. In vivo experiment was conducted on four seedlings of bird pepper, bush bean, garden pea, and tomato. It was concluded that 30 gm of Muscodor cinnamomi prepared on rye grain solid media is the minimum dose required for inhibition of Rhizoctonia infection and total control and elimination of damping off symptoms. Muscodor cinnamomi-infected soil does not show any seed germination inhibition in comparison to Rhizoctonia solani-infected soil. So it is a type of pioneer study of using endophytic species as potent agents of fumigation and biocontrol. Candida intermedia strain C410 (Saccharomycetaceae) was isolated as an endophyte of strawberry (Fragaria ananassa), and the volatile emission was known to be a mixture of 49 organic compounds including esters, alcohols, alkenes, alkanes, alkynes, organic acids, ketones, and aldehydes of which 1, 3, 5, 7-cyclooctatetraene and 3-methyl-1-butanol were the most dominant (Huang et al. 2011). Volatiles of strawberry endophyte were itself useful as postharvest control agent for the host plant against Botrytis fruit rot. Other compounds include 1,3,5,7-cyclooctatetraene; 3-methyl-1-butanol; 2-nonanone; pentanoic acid, 4-methyl-, ethyl ester; 3-methyl-1-butanol, acetate; acetic acid, pentyl ester; and hexanoic acid, ethyl ester that were found to be extremely inhibitory to conidial germination (reproductive growth) and also vegetative (mycelial) proliferation of $B$. cinerea. When the fruits are exposed to $C$. intermedia synthetic volatiles or itself to the fungus, the incidence of Botrytis fruit rot reduces significantly. Strawberry fruits inoculated directly with the endophyte also remain disease-free. So mixtures of Candida intermedia $\mathrm{C} 410$, the unique natural products, are useful as mycofumigation technique or for postharvest disease management by biological control policies.

Tangerine fruit (Citrus tangerine), the commercial citrus crop of Northern Thailand, faces huge postharvest losses due to pathogenesis of green mold (Penicillium digitatum). The pathogen is the prime cause of worldwide deterioration of tangerine fruits by mycopathogenesis. Out of 32 detected compounds, the most predominant were 2-methylpropanoic acid and 3-methylbutan-1-ol. Other compounds include carbitol, octanoyl chloride, azulene, 3-methylhexane, 2-methylpropan-1-ol, 2,3-butanediol, caryophyllene, 2-methylbutyric acid, ethyl 2-hydroxyproponate, etc. The pathogen was treated both in vitro and in vivo for their inhibition by endophytic volatile components. In both cases, pathogen growth was restricted. During transportation of the fruits, fungus causes huge crop loss by infecting the fruits; when fruits were inoculated with $30 \mathrm{gm}$ of rye grain culture of 
M. suthepensis (1 month old), the disease development is ceased. So it is a classic example of mycofumigation by the biocontrol agent of tangerine fruit for the control of rot lesions caused by $P$. digitatum infection. The in vivo application requires the proper surface sterilization (using sodium hypochlorite) of the targeted parts where the inoculation is going to be done, for example, fruit, stem, root, and leaf. Usually infection on fruits for assessing the biocontrol potential is the most common and popular method. The seeds will be washed in distilled water, and using sterile needle, uniformly the whole area would be done, and the whole area would be infected or inoculated with the endophytic liquid extracts containing spore suspensions. Muscodor albus VOCs are potent enough to cause a significant reduction of in vitro spore germination of the Tilletia species T. horrida, T. indica, and T. tritici. Endophytic Nodulisporium spp., Trichoderma spp., Phomopsis spp., and Oxyporus latemarginatus are reported to produce VOCs that inhibit mycelial growth of phytopathogenic fungi (Lee et al. 2009; Park et al. 2010; Ajith and Lakhsmidevi 2010; Amin et al. 2010). Black sigatoka disease (also known as leaf spot or black leaf streak disease) of banana (Musa paradisiaca) is caused by Mycosphaerella fijiensis (ascomycete fungus). This phytopathogen is inhibited by the volatile emissions of Muscodor sutura, an endophytic isolate of Prestonia trifidi. The volatiles are effective also against Ceratocystis ulmi, the causal agent of Dutch elm disease of American elm (Ulmus americana). The volatile mixtures include thujopsene, chamigrene, isocaryophyllene, and butanoic acid, 2-methyl- that are potent inhibitors of the common anthracnose pathogen of cucumber, muskmelon, and watermelon (members of cucurbits), Colletotrichum lagenarium. So this unique endophyte and its chemical mixtures are potent mycofumigants and ensure crop protections against destructive pathogens like C. ulmi and C. lagenarium, Sclerotinia sclerotiorum (causing white mold, cottony rot, water soft rot, stem rot, drop, crown rot, and blossom blight diseases of the host), and also Phytophthora palmivora (oomycete fungi), the causal agent of bud root of palms and areca nut predominantly occurring in regions of South India (Kudalkar et al. 2012). Liarzi and his coworkers tested the biological control efficacy of the endophytic Daldinia cf. concentrica, isolated from olive tree (Olea europaea L.) of Israel against 18 phytopathogens, and the unique mixtures of 27 volatile were effective against the phytopathogenic mycelial growths. The mixtures include a variety of organic compounds: 3-methyl-1-butanol, 2-methyl-1-butanol, 1-methyl-1,3-cyclohexadiene, 1-methyl-1,4-cyclohexadiene, 4-heptanone, isoamyl acetate, 4-heptyn-2-ol, 2 -octenal, octanal, $\beta$-elemene, $\alpha$-guaiene, $\beta$-selinene, $\alpha$-selinene, $\alpha$-bulnesene, germacrene A, etc. The unique mixtures having broad-spectrum antifungal property could be used for fumigation for eliminating the pathogenic infections of Aspergillus niger (mold-causing organism on fruits of economic importance). So the endophytic $D$. cf. concentrica opens up opportunities for fungal disease control in food and agricultural industries (Liarzi et al. 2016). Nodulisporium sp. strain GS4d2II1 (Hypoxylon anthochroum) and Hypoxylon anthochroum strain Blaci are potent enough to be used as biopesticide against Fusarium oxysporum, a common contaminant of Solanum lycopersicum var. cerasiforme (cherry tomato) causing a great percentage of crop loss globally. Six VOCs of alcohols' mixture, phenylethyl 
alcohol, 2-methyl-1-butanol, 3-methyl-1-butanol, eucalyptol, ocimene, and terpinolene, were detected and applied together with synergistic effect and individually both in vitro and in vivo. Inoculation of pathogen on the cherry tomato fruits yields significant reduction in Fusarium contamination. Both agar dilution techniques and gas test were done to assess the in vitro antifungal activity, and the endophytic volatile mixtures were effective in both the cases. Volatiles kill the pathogens probably by interfering cell membrane permeability, hyphal morphology, and respiratory activity of the pathogenic Fusarium oxysporum. So it is a great opportunity to use the unique mixture of volatile organic compounds of the endophytic isolate to reduce the crop loss caused by the pathogenic infection on the commercially valuable plant of cherry tomato worldwide. Endophytic Phoma sp. (Didymellaceae) and Phomopsis sp. (Valsaceae) were isolated from Larrea tridentata and Odontoglossum sp. (Strobel et al. 2011; Singh et al. 2011). The volatiles detected are effective against phytopathogens Verticillum sp., Ceratocystis sp., Cercospora sp., Sclerotinia sp. Sclerotinia sp., and Botrytis sp.

\subsection{Seaweeds as Natural Fungicides}

Algae are diverse group of autotrophs and the leading producers of $\mathrm{O}_{2}$ in the ecosystem. They range from prokaryotic unicellular to eukaryotic complex multicellular forms involved in the marine and terrestrial food chain. Antifungal activity of the seaweed (members of Phaeophyceae and Rhodophyceae) is a major weapon for natural fungicides along with their antibacterial, anti-protozoan, and antiviral activities. Algal seaweeds are potent holders of large number of secondary metabolites including phenolics, terpenes, alkaloids, and lectins which are not directly involved in photosynthesis and reproduction and thus fall under the category of secondary metabolites. They are common antimicrobial of algal origin that act on the target organisms by altering the microbial cell permeability accompanied with the loss of internal macromolecules or sometimes interfere with the membrane function causing cellular disintegrity ultimately leading to cell death (Abu-Ghannam and Rajauria 2013). Several studies include antifungal activity of algal members against human pathogens; a very few studies include their efficacy against plant pathogens (Cheung et al. 2014; Singh et al. 2007; Stirk et al. 2007; Padmakumar and Ayyakkannu 1997; Ismail et al. 2014; Genovese et al. 2013; Lopes et al. 2015). Padmakumar and Ayyakkannu tested 80 species of algae against a variety of bacterial and fungal pathogens. Out of the all screened organisms, $70 \%$ exhibited antibacterial efficiency, and only $27.5 \%$ inhibited fungal growth. Polysaccharides found in the cell wall and deposited in terms of storage food from red and brown algal sources include ulvans (obtained from Ulva sp.), alginates and fucans (from Fucus sp.), laminarin (Laminaria sp.), and carrageenans that can induce defense responses in plants against phytopathogens by pathogen-associated molecular patterns (MAPs) and are capable of inducing plant resistance (Vera et al. 2011). Polysaccharides stimulate regular cellular changes associated with pathogen perception and defense activation by change in $\mathrm{Ca}^{2+}$ concentration and burst due to oxidative stress 
activation of salicylate, ethylene, and jasmonate biosynthetic pathways and by activating pathogenesis-related proteins (PRPs) (Jaulneau et al. 2010; Zhao et al. 2012). As a result of the depolymerization of the polysaccharides, the obtained oligosaccharides induce protection against a variety of fungal, viral, and bacterial diseases by accumulation of the antimicrobial compounds in the cell. Algal polysaccharides as an alternative weapon over the synthetic agricultural drugs for controlling plant disease have been widely studied (Stadnik and Freitas 2014; Hahn et al. 2008).

\subsubsection{Laminarin: Defense-Inducing Polysaccharide from Brown Algae}

Brown algae Laminaria digitata, a genus of Phaeophyceae, is commonly called seaweeds and known to be the potent producers of kelp, an iodine-rich substance needed for the normal functioning of thyroid gland. Laminaria produces laminarin, glucan polysaccharide-containing 1,3-linked $\beta$-d-glucose moiety, a reserve food material found on the vacuoles of the vegetative cells of this genus. $\beta$-Glucans are involved as a major part of daily diet and obtained from the brands of common cereals. They are involved in the defense responses of agricultural crops like tomato (Lycopersicon esculentum), eggplant (Solanum melongena), pepper (Piper nigrum), watermelon (Citrullus lanatus), grape (Vitis vinifera), apple (Malus sp.), and pear (Pyrus communis). Elicitation of defense response by laminarin against causal agents of gray mold (Botrytis cinerea) and downy mildew (Plasmopara viticola) in grapevine plants remarkably suppresses their infection up to $55 \%$ and $75 \%$, respectively (Copping et al. 2004). So, natural product from brown algae Laminaria sp. known as laminarin or laminaran can act as the biofungicide or biocontrol compounds. Use of laminarin significantly reduces the mycelial growth and aflatoxin production in Aspergillus flavus and ensures its use as a fungicide (Liangbin et al. 2012). The advantage of using laminarin over other products is that as it breaks down finally to glucose molecules, it has no maximum residue limit (MRL) on the plant treated with this product. So, there is no need of preharvest interval constraint. This has been a prime cause why laminarin has substituted five popular fungicides involved in the treatment of apple scab (Venturia inaequalis) in France (Mery et al. 2013). This phyto-pharmaceutical is used widely in France and some countries of Europe in the name of Vacciplant (major active constituent is laminarin). Laminarin has broad-spectrum applicability on fire blight of apples and pears in Greece, France, Belgium, Switzerland, Portugal, and also Morocco. It is effective for apple scab disease in France and Belgium and for curing storage diseases of apples caused by Gloeosporium sp. in Belgium. Laminarin comes out as a fungicide of natural origin after being eligible in 33 tests between 2001 and 2011 in several parts of Europe, for example, France, Belgium, Italy, and Poland, on natural contamination of orchards on several sensitive strains of scab fungus including Golden Delicious, Golden Smoothie, Read Cheaf, Galaxy, Gala, and Pink Lady. Laminarin is applied widely against secondary scab (to minimize secondary scab during summer and up to harvest) as a result of its uniqueness in its mode of action. It does not involve cell 
death of the host plant or hypersensitivity induction in the host organism but rather stimulates plants' natural resistance (Klarzynski et al. 2000). Aziz et al. (2003) reported its effectiveness in tobacco plants, wheat, strawberries, apples, and vines. The application of laminarin and alginate reduced the development of wilt symptoms caused by Verticillium dahliae on olive twigs, stimulating its phenolic metabolism (Salah et al. 2018). Moreover, alginates reduced pathogen growth in vitro. Laminarin induces the release of $\mathrm{H}_{2} \mathrm{O}_{2}$ in cells of tobacco plants and leads to the increase in PAL activity (phenylalanine ammonia-lyase) and causes the accumulation of PR-1, PR-2 (glucanase), PR-3 (chitinase), and PR-5. Concerning red algae polysaccharides, carrageenans induced protection against a broad range of pathogens such as tobacco mosaic virus (TMV), B. cinerea, and E. carotovora on tobacco (Vera et al. 2011). Again on tobacco, Mercier et al. (2001) showed that carrageenan infiltrated the leaves and increased the expression of genes coding for a sesquiterpene cyclase involved in the synthesis of the antimicrobial terpenoid capsidiol, PR-3 proteins (basic chitinases), and proteinase inhibitor with antipathogenic activity. An adequate percentage of growth and spore germination inhibition of Botrytis cinerea was mediated by the hexane extracts of Laminaria digitata and Undaria pinnatifida. Porphyra umbilicalis, laverbread, is an edible seaweed (Corato et al. 2017). Other than B-glucan polysaccharides (laminarin) of Laminaria, other secondary metabolites (phenols, terpenes) of phaeophycean algae (Sargassum sp.) showed effectivity against common pathogens Fusarium solani, Rhizoctonia solani, Aspergillus spp., Fusarium oxysporum, Penicillium spp., and Botrytis cinerea (Khallil et al. 2015; Ibraheem et al. 2017; Mabrouk et al. 1985; Liu et al. 2014).

\subsubsection{Cyanobacterial Polysaccharides Versus Fungal Infection}

Cyanophycean blue-green algae are abundant all over the world and ranging from pond ecosystem to oceanic system. Though they have been reported to produce a large number of toxins and involved in death and disease of cattle and human being, they are of serious interest from the point of view of natural fungicidal products. Drawing the similarities with bacteria, they are characterized with a mucilaginous or gelatinous sheath composed of polysaccharides which are the weapon against fungal pathogenesis. Cyanobacterial polysaccharides (POL) show higher disease resistance against $B$. cinerea when they are applied on the intact fruit (preharvest conditions when fruit is attached to the plant) rather than the fruit detached (postharvest conditions) from the plant (Zheng et al. 2011; Feliziani et al. 2015; Yao and Tian 2005). Polysaccharides are involved in elicitation as elicitors for development of local and systemic disease resistance and expression of defense enzyme synthesis, for example, chitinases and glucanases that are involved directly in antifungal responses (Paulert et al. 2009; Reymond and Farmer 1998; Sharma et al. 2014). Water extracts of common BGA Anabaena sp., Ecklonia sp. (common edible marine algae of Japan and Korea), and Corallina sp. (hard seaweed of Corallinaceae family) exhibit antifungal activity against Podosphaera xanthii (causal agent of powdery mildew of cucurbits) on zucchini plant, Cucurbita pepo, of Cucurbitaceae 
(Roberti et al. 2015, 2016). In the recent past, fungi inhibitory ability of algal members has been reported by several workers (Righini et al. 2018; Corato et al. 2017; Khallil et al. 2015; Ibraheem et al. 2017). In vitro growth inhibition of Aspergillus oryzae and Penicillium notatum has been seen by cyanophycean Anabaena laxa (Frankmölle et al. 1992). Devastating plant pathogens Pythium sp., Fusarium sp., and Rhizoctonia sp. were restricted by extracts of Anabaena sp. (Moon et al. 1992; Manjunath et al. 2010). The use of BGA extract as the growth inhibitor of pathogenic Chaetomium globosum, Cunninghamella blakesleeana, Aspergillus oryzae, Rhizoctonia solani, Fusarium sp., Pythium sp., and Sclerotinia sclerotiorum is reported. The extracts of Phormidium fragile and Nostoc muscorum (Rizk 2006) are effective control agents of sugar beet pathogens (Sclerotium rolfsii, Rhizoctonia solani, Fusarium verticillioides). The common root rot pathogen Rhizoctonia solani is inhibited by the extracts of cyanophycean algae Nostoc entophytum and N. muscurum (Osman et al. 2011). The recent investigations of Dukare et al. (2011) included the inhibitory activity of three strains of BGA $(\mathrm{C} 4, \mathrm{C} 8, \mathrm{C} 12)$ against $F$. solani, F. oxysporum, F. oxysporum f. sp. lycopersici, F. moniliforme, $P$. debaryanum, and $R$. solani. Righini et al. (2018) reported for the first time about the resistanceinducing ability of the polysaccharides of the brown (Ecklonia sp.), red (Jania sp.), and cyanophycean algae (Anabaena sp.) and their possible role in disease control ability. Study on zucchini plant revealed the enhancement of defense-related enzyme on the plant mediated by the treatment of Anabaena extract (Roberti et al. 2015). Water extracts of Ecklonia sp., Anabaena sp., and Corallina sp. are potent antifungals against Podospora xanthii on zucchini plant (Roberti et al. 2016).

\subsection{Plant Amphibians as an Alternative Source}

Bryophytes, the simplest member of the broad umbrella of Embryophyta, are situated between algae and pteridophytes, are known to be plant amphibians growing in the marshy or shady habitat, and require water for their fertilization and for the perfect swimming motility of their sperms. They have been evaluated for their antimicrobial activity for a long time. It has been proved that these cryptograms are rich source of bioactive secondary metabolites and can easily be exploited as an alternative source of fungicidal compounds. As they grow in marshy habitats and can protect themselves from biotic (ultraviolet rays, heat stress, and predation) and abiotic stress (fungal or bacterial attack), they are store house of diverse bioactive chemicals (Xie and Lou 2008). Members of Hepaticopsida and mosses (the evolved members of bryophytes) are known to possess antifungal activity and are rich source of flavonoids, terpenoids, bibenzyls, and fatty acids of therapeutic importance (Krzaczkowski et al. 2008). Bryophytes are known to possess antibiotic property (Banerjee and Sen 1979; Banerjee 2000; Singh et al. 2007; Shirzadian et al. 2009; Savaroglu et al. 2011). Their antibiosis has been evaluated against a large number of plant and human pathogenic fungus (Mekuria et al. 2005). Antimicrobial compounds from bryophyte can cure the problems of conventional antibiotic resistance (Vanden Bossche et al. 1998). The antifungal efficacy is tested by disc diffusion 


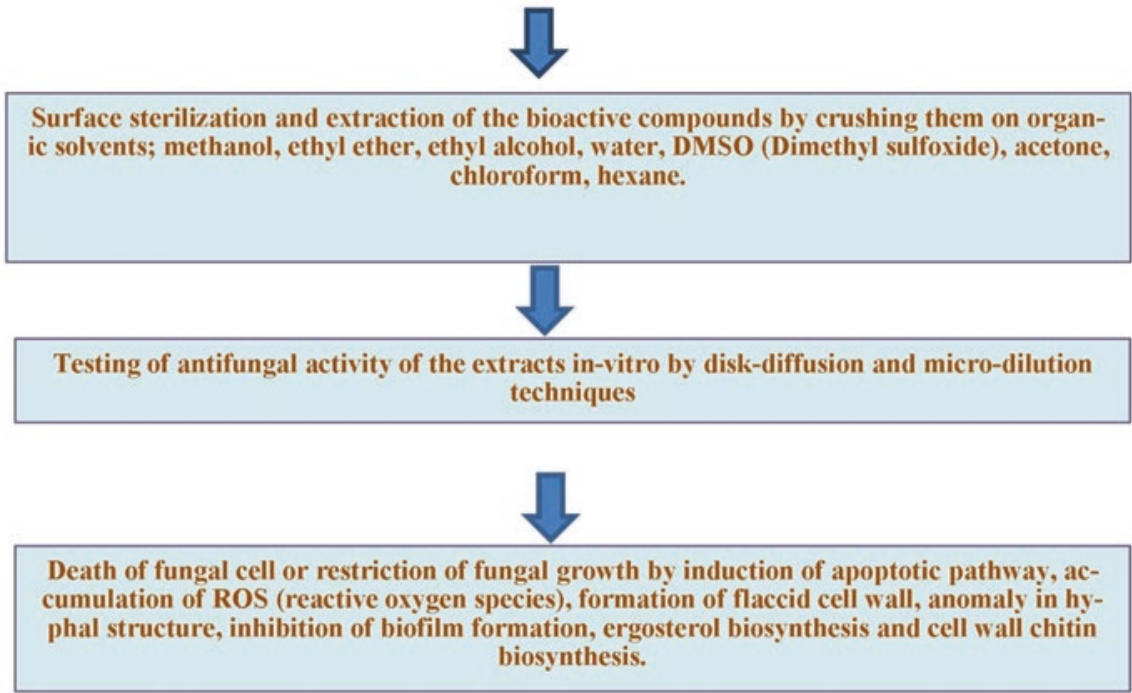

Fig. 9.5 Pharmacological extraction of bioactive compounds from bryophytes

assay and microdilution method (Fig. 9.5). Different concentrations of the extracts are prepared and checked for their antifungal efficacy against phytopathogenic fungi. They may be fungicidal or fungistatic in nature, interfering at cellular, genetic level and creating blockage at metabolic pathways. Extracts are made on several organic solvents or water extractions and also mixture of one or two organic solvents. The solvents popularly used are ethanol, methanol, chloroform, ether, dimethyl sulfoxide (DMSO), acetone, chloroform, and hexane (Table 9.5). Sporophytes and gametophytes of different bryophytes at different stages of growth and at a different amount are first surface sterilized and then crushed on the organic solvents and used as antifungals in vitro against the fungal pathogens (Wolters 1964). A large number of phytopathogenic fungi (A. niger, R. bataticola, F. moniliforme, Penicillium funiculosum, T. viride, P. ochrochloron, A. versicolor, A. fumigatus Trichoderma viride, Aspergillus niger, A. flavus, P. funiculosum, Tilletia indica, Sclerotium rolfsii, R. solani, Penicillium ochrochloron, Alternaria alternate, Botrytis cinerea, Botryodiplodia theobromae, F. oxysporum f. sp. gladioli, Penicillium expansum, $P$. chrysogenum, Trichoderma viride) are reported to be partially or completely inhibited by the bryophyte extracts of Marchantia polymorpha, Atrichum undulatum, Physcomitrella patens, Rhodobryum ontariense, Ctenidium molluscum, Ptilidium pulcherrimum, Hypnum cupressiforme, Fontinalis antipyretica var. pyretica, Plagiochasma appendiculatum, and Dumortiera hirsuta (Sabovljevic et al. 2011; Pejin et al. 2012; Veljic et al. 2009; Gahotri and Chaturvedi 2011; Alam et al. 2011; Deora and Jain 2008; Dey and De 2011; Deora and Suhalka 2017). 
Table 9.5 Antifungal activity of extracts of bryophytes

\begin{tabular}{|c|c|c|c|}
\hline Extractions & Bryophyte genus & Antifungal against & References \\
\hline Organic solvent extracts & $\begin{array}{l}\text { Scleropodium purum, } \\
\text { Sphagnum fimbriatum, } \\
\text { S. nemoreum, S. } \\
\text { subsecundum, } \\
\text { Pogonatum aloides, } P \text {. } \\
\text { urnigerum, Polytrichum } \\
\text { commune, P. formosum, } \\
\text { Plagiothecium } \\
\text { denticulatum, Mnium } \\
\text { hornum, Oligotrichum } \\
\text { hercynicum, Atrichum } \\
\text { undulatum, F. } \\
\text { antipyretica }\end{array}$ & $\begin{array}{l}\text { C. cerebella, B. alli, } \\
\text { P. oryzae, } P \text {. } \\
\text { versicolor, } \\
\text { F. bulbigenum, } \\
\text { Rhizoctonia solani, }\end{array}$ & $\begin{array}{l}\text { Wolters et al. } \\
\text { (1964) and } \\
\text { Savaroglu et al. } \\
(2011)\end{array}$ \\
\hline $\begin{array}{l}\text { A-Herbertenol, } \\
\beta \text {-herbertenol, } \\
\alpha \text {-formylherbertenol, } \\
\beta \text {-bromoherbertenol }\end{array}$ & Herbertus aduncus & $\begin{array}{l}\text { Botrytis cinerea, } \\
\text { Rhizoctonia solani }\end{array}$ & $\begin{array}{l}\text { Matuso et al. } \\
\text { (1986) }\end{array}$ \\
\hline $\begin{array}{l}\text { 5- and } \\
\text { 7-Hydroxycalamenenes, } \\
\text { drimenol, drimenal, } \\
\text { viridiflorol, gymnomitrol, } \\
\text { bisbenzyls }\end{array}$ & Bazzania trilobata & $\begin{array}{l}\text { Botrytis cinerea, } \\
\text { Cladosporium } \\
\text { cucumerinum, } P . \\
\text { infestans, } \\
\text { Pyricularia oryzae, } \\
\text { Septoria tritici }\end{array}$ & $\begin{array}{l}\text { Scher et al. } \\
(2004)\end{array}$ \\
\hline $\begin{array}{l}\text { Trans- } \beta \text { - } \\
\text { methylthioacrylate }\end{array}$ & Balantiopsis cancellata & $\begin{array}{l}\text { Cladosporium } \\
\text { herbarum }\end{array}$ & $\begin{array}{l}\text { Labbe et al. } \\
(2005)\end{array}$ \\
\hline $\begin{array}{l}\text { Ether, alcohol, and hexane } \\
\text { extract }\end{array}$ & $\begin{array}{l}\text { Pallavicinia lyellii, } \\
\text { Scapania verrucosa }\end{array}$ & $\begin{array}{l}\text { Aspergillus niger, } F \text {. } \\
\text { oxysporum, } P \text {. } \\
\text { oryzae }\end{array}$ & $\begin{array}{l}\text { Subhisha and } \\
\text { Subramoniam } \\
\text { (2005), Guo } \\
\text { et al. (2008) }\end{array}$ \\
\hline $\begin{array}{l}\text { Methanol and ethanol } \\
\text { extracts }\end{array}$ & $\begin{array}{l}\text { Pleurozium schreberi, } \\
\text { Palustriella commutata, } \\
\text { Homalothecium } \\
\text { philippeanum, } \\
\text { Anomodon attenuatus, } \\
\text { Rhytidium rugosum, } \\
\text { Hylocomium splendens, } \\
\text { Dicranum scoparium, } \\
\text { Leucobryum glaucum }\end{array}$ & $\begin{array}{l}\text { Variety of } \\
\text { phytopathogens } \\
\text { A. niger, } \\
\text { P. ochrochloron }\end{array}$ & $\begin{array}{l}\text { Sabovljevic } \\
\text { et al. (2006), } \\
\text { Veljic et al. } \\
(2009)\end{array}$ \\
\hline Aqueous extracts & $\begin{array}{l}\text { Plagiochasma } \\
\text { appendiculatum, } \\
\text { Dumortiera hirsute }\end{array}$ & $\begin{array}{l}\text { Alternaria alternate, } \\
\text { A. niger, Botrytis } \\
\text { cinerea, } \\
\text { Botryodiplodia } \\
\text { theobromae, } F . \\
\text { oxysporum f. sp. } \\
\text { gladioli, Penicillium } \\
\text { expansum, } P . \\
\text { chrysogenum, } \\
\text { Trichoderma viride }\end{array}$ & $\begin{array}{l}\text { Deora and Jain } \\
(2008) \text { and } \\
\text { Alam et al. } \\
(2011)\end{array}$ \\
\hline
\end{tabular}


Table 9.5 (continued)

\begin{tabular}{|c|c|c|c|}
\hline Extractions & Bryophyte genus & Antifungal against & References \\
\hline $\begin{array}{l}\text { Acetone, ethanol, } \\
\text { chloroform, and distilled } \\
\text { water extracts }\end{array}$ & $\begin{array}{l}\text { Thuidium delicatulum, } \\
\text { Plagiochasma } \\
\text { appendiculatum, Bryum } \\
\text { argenteum, B. cellulare }\end{array}$ & $\begin{array}{l}\text { A. niger, } R \text {. } \\
\text { bataticola, } F \text {. } \\
\text { moniliforme }\end{array}$ & $\begin{array}{l}\text { Bodade et al. } \\
\text { (2008) }\end{array}$ \\
\hline $\begin{array}{l}\text { Methanolic and } \\
\text { chloroform extracts }\end{array}$ & $\begin{array}{l}\text { Ctenidium molluscum, } \\
\text { Ptilidium pulcherrimum, } \\
\text { Marchantia polymorpha, } \\
\text { Hypnum cupressiforme, } \\
\text { Fontinalis antipyretica } \\
\text { var. pyretica }\end{array}$ & $\begin{array}{l}\text { Trichoderma viride, } \\
\text { Aspergillus niger, A. } \\
\text { flavus, } P . \\
\text { funiculosum, Tilletia } \\
\text { indica, Sclerotium } \\
\text { rolssii, } R \text {. solani, } \\
\text { Penicillium } \\
\text { ochrochloron }\end{array}$ & $\begin{array}{l}\text { Veljic et al. } \\
\text { (2009), Gahotri } \\
\text { and Chaturvedi } \\
\text { (2011) }\end{array}$ \\
\hline DMSO extracts & $\begin{array}{l}\text { Marchantia polymorpha, } \\
\text { Atrichum undulatum, } \\
\text { Physcomitrella patens, } \\
\text { Rhodobryum ontariense }\end{array}$ & $\begin{array}{l}\text { Penicillium } \\
\text { funiculosum, } T \text {. } \\
\text { viride, } P . \\
\text { ochrochloron, } A \text {. } \\
\text { versicolor, } A \text {. } \\
\text { fumigatus } \\
\end{array}$ & $\begin{array}{l}\text { Sabovljevic } \\
\text { et al. (2011), } \\
\text { Pejin et al. } \\
(2012)\end{array}$ \\
\hline $\begin{array}{l}\text { Acetone and methanol } \\
\text { extracts }\end{array}$ & Riccia gangetica & Curvularia lunata & $\begin{array}{l}\text { Deora and } \\
\text { Suhalka } \\
(2017), \text { Deora } \\
\text { and Guhil } \\
(2015,2016)\end{array}$ \\
\hline
\end{tabular}

\subsection{Ray Fungi-Based Antifungal Activities}

Actinobacteria are a group of gram-positive filamentous bacteria that are called as the branched bacteria or ray fungi (from Greek actis, ray beam, and mykes, fungus) and are characterized with the high $\mathrm{G}+\mathrm{C}$ content occurring in mostly aerobic conditions but occasionally being anaerobes (Ludwig and Klenk 2005; Olanrewaju and Babalola 2019). Their morphology varies from forming branching filaments or mycelial growth to external spores. They are ubiquitous in nature ranging their distribution from soil and human microbiota to plant and even animal kingdom. They are predominant in aquatic as well as terrestrial ecosystem playing a major part in mineralization and recycling of organic matters leading to soil formation (Sharma et al. 2014). They are not only free-living members of the ecosystem but also a plant symbiont or endophyte, contributing to the plants' survival in extreme conditions and pursuing several bioactivities in vivo and in vitro. Actinomycetes produce a diverse range of secondary metabolites, for example, antibiotics, antitumor, insectrepellent, and immunosuppressive agents, and plant growth-promoting regulators (PGPRs) that are of immense pharmaceutical and agricultural importance. They are the prime producers of diverse antibiotics after the landmark discovery of penicillin in the year 1928. The single genus of Streptomyces sp. itself produces $76 \%$ of the total known bioactive $(10,000$ are produced by actinobacteria out of 23,000 produced by microorganisms, almost $45 \%$ ) compounds from actinobacterial and 
bacterial source (Berdy 2012) and is known to be the prime organism in the pharmaceutical world. They are equally profitable when isolated from plant source and designated as endophytic actinomycetes. So exploitation of the actinobacterial novel bioactive compounds both from endophytic and non-endophytic source is the ultimate way to fight against human and plant diseases. Here we focus only on actinobacterial compounds' antifungal activity and role in plant protection from deadly diseases caused by severe phytopathogens leading to irreparable crop loss and economic breakdown of agricultural sectors.

\subsubsection{Isolation, Identification, and Detection of Bioactive Compounds with Anti-phytopathogenic Activity}

Actinomycetes from soil source are selected based on the enrichment culture technique and are plated on selective media for isolation. Antifungal agents, for example, nystatin and cycloheximide, are supplemented for the inhibition of fungal contamination. For isolation of endophytic actinobacteria from plant source, plants are first selected and surface sterilized for the elimination of the epiphytic contaminants and finally plated on the selective growth media like starch casein nitrate agar (SCNA), chitin-vitamin B, tap water yeast extract agar (TWYA), soybean, humic acid-vitamin B (HV), yeast extract casamino acid (YECA), modified Gausse, and glycine-glycerol (Ivantiskaya et al. 1978; Küster 1959; Küster and Williams 1964; Williams and Davies 1965; Hayakawa and Nonomura 1987; Crawford et al. 1993). International Streptomyces Project (ISP) medium is also popular media used for isolation, and they are supplemented with amino acids (L-asparagine for ISP 5, tryptone for ISP 1), inorganic trace salts, starch or carbohydrate sources (malt extract for ISP 4), and agar as solidifying agent. $\mathrm{pH}$ set at near to optimum or slightly basic is mandatory for proper isolation techniques using ISP medium. The actinomycete isolates are grown in solid or liquid medium for their antifungal bioactivity detection. Antagonistic activities of the potent isolates are tested by growing them on both sides of the fungal hyphae, and isolate having anti-phytopathogenic activity will inhibit the growth of the pathogens. Actinobacterial aqueous- or solvent-based extracts will be evaluated for either fungistatic or fungicidal activity by agar welldiffusion techniques. Soluble bioactive compounds of antifungal importance will be extracted using wide range of organic solvents followed by purification by column and thin-layer chromatographic techniques. HPLC analysis will be the most useful method for the detection of the purity of the compound, and further NMR studies are needed for the proper identification of the bioactive compound. Cell line studies are made with the coupling of bioinformatics tools for the proper knowledge about their mode of action. 


\subsubsection{Role in Plant Protection}

\subsubsection{Actinobacterial Flora Producing Antibiotics of Agricultural Importance}

Actinobacteria can be a part of plant as endophyte, rhizospheric soil as symbiont for plant growth-promoting substance producer, and organisms' normal microbial flora as gut microorganism. So they are ubiquitous in their distribution. Out of several biologically potent compound produced from the actinobacterial source, antibiotics are the major contribution of these microorganisms toward human civilization. All the known antibiotics (blasticidin, mildiomycin, natamycin, validamycin, kasugamycin) are of actinobacterial (most of them are the Streptomyces sp.) source showing protective activity for the plants against agricultural fungal pathogens (Tables 9.6 and 9.7).

\subsubsection{Endophytic Actinomycetes}

As human are dependent completely on nature and more particularly natural components of agricultural origin and importance, dependence on agricultural crops is of a known fact. But the problem arises when the crops are affected most by the fungal pathogens leading to huge crop loss, and thus the search for novel antibiotics is on, and the search has shifted to actinobacterial source, and endophyte plays an important role in this respect. There are significant reports of antifungal compounds from bacterial origin, but now the focus has shifted to microbes of endophytic origin (Table 9.8). Till date, a huge number of antibiotics are already reported and have minimized the crop loss to a notable amount (Fig. 9.6). Antibiotics and other antifungal compounds include munumbicins A, B, C, D, E-4, and E-5, vanillin, saadamycin, 5,7-dimethoxy-4-p-methoxyphenyl coumarin, coronamycin, and fistupyrone isolated from different strains of Streptomyces sp. (Streptomyces aureofaciens CMU Ac 130, Streptomyces sp. NRRL 30562, Streptomyces sp. Hedaya48, Streptomyces sp. MSU-2110, Streptomyces sp. TP-A0569) and from different parts (stem, leaf, inflorescence, root, fruit, internal healthy tissues) of diverse medicinal plants, for example, Kennedia nigricans (Fabaceae), Aplysina fistularis (yellowgreen candle sponge or yellow tube sponge), Monstera sp. (Monsteraceae), Allium fistulosum (Liliaceae), and Zingiber officinale (Zingiberaceae) of different regions all over the world. The bioactive compounds are effective against a wide range of phytopathogens including Magnaporthe oryzae, Fusarium graminearum, F. oxysporum f. sp.lycopersici, F. oxysporumf. sp.cubense, F. verticillioides, Colletotrichum sp., Pestalotiopsis sp., Diaporthe sp., Xylaria sp., P. aphanidermatum, Pythium oligandrum, Pythium ultimum, Pythium aphanidermatum, Phytophthora cypogea, Phytophthora cactorum, Phytophthora infesta, Fusarium solani, Aspergillus fumigatus, Mycosphaerella fijiensis, Sclerotinia sclerotiorum, Rhizoctonia solani, and Phytophthora erythroseptica (Shan et al. 2018; Costa et al. 2013; Igarashi et al. 2002; Tian et al. 2004; Zin et al. 2007) and are protecting a large number of cereals and other important cash crops from being affected by these common contaminants. Endophytic actinobacteria directly counteract with fungal plant pathogens not only by producing bioactive compounds but also by enhancing the plant's growth through 


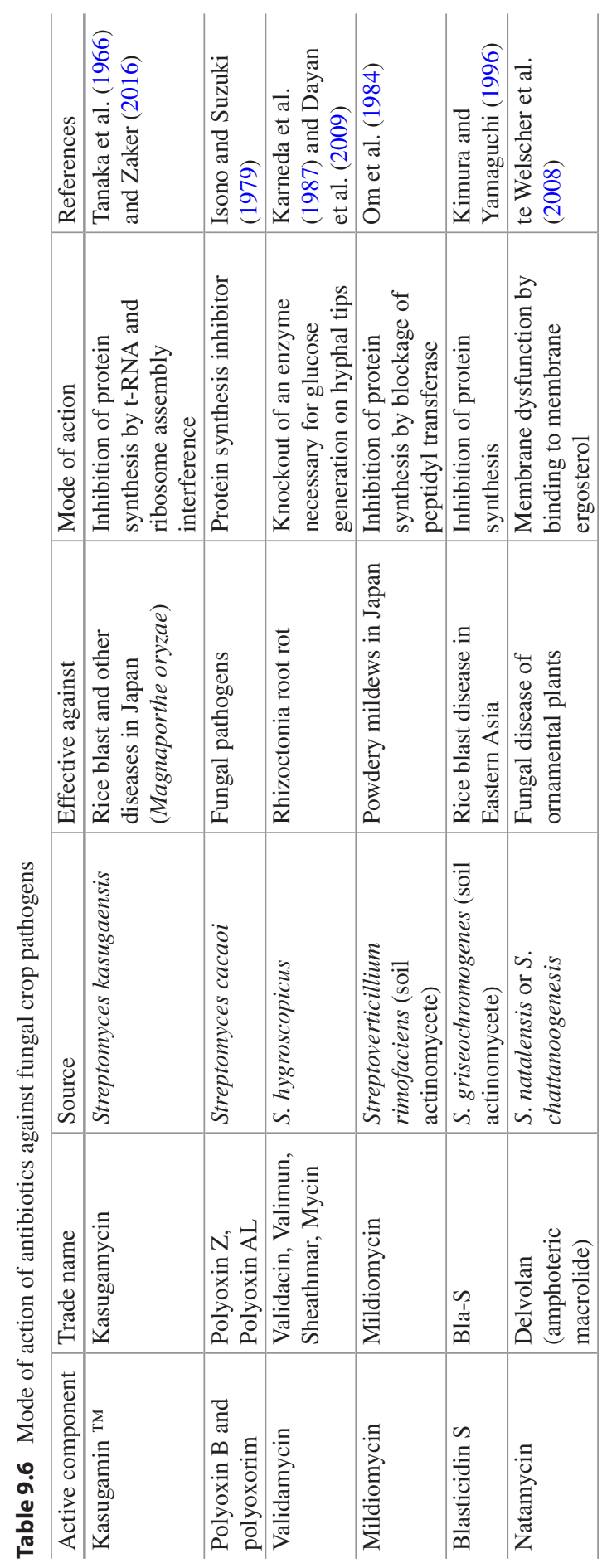


Table 9.7 Antifungal activity of different species of Streptomyces

\begin{tabular}{|c|c|c|}
\hline Actinomycetes & Antifungal against & References \\
\hline Streptomyces griseus & Rhizoctonia solani & $\begin{array}{l}\text { Merriman et al. } \\
\text { (1974) }\end{array}$ \\
\hline Streptomyces kasugaensis & Fusarium sp. & $\begin{array}{l}\text { De Vasconcellos } \\
\text { and Cardoso } \\
(2009)\end{array}$ \\
\hline Streptomyces sp. & $\begin{array}{l}\text { Alternaria brassicae, } \\
\text { Colletotrichum gloeosporioides, } \\
\text { Rhizoctonia solani, Phytophthora } \\
\text { capsici }\end{array}$ & $\begin{array}{l}\text { Srividya et al. } \\
\text { (2012) }\end{array}$ \\
\hline Streptomyces sp. & Sclerotium rolfsii & $\begin{array}{l}\text { Gholami et al. } \\
(2014)\end{array}$ \\
\hline Streptomyces griseus $\mathrm{E} 44 \mathrm{G}$ & $\begin{array}{l}\text { Fusarium oxysporum f. sp. } \\
\text { lycopersici }\end{array}$ & $\begin{array}{l}\text { Al-Askar et al. } \\
(2015)\end{array}$ \\
\hline Streptomyces sanglieri & Ganoderma boninense & $\begin{array}{l}\text { Azura et al. } \\
(2016)\end{array}$ \\
\hline \multirow{2}{*}{$\begin{array}{l}\text { APA2 Streptomyces } \\
\text { longisporoflavus, AAH53 } \\
\text { Streptomyces mutabilis, APC70 } \\
\text { Streptomyces griseus }\end{array}$} & $\begin{array}{l}\text { Alternaria solani, } \\
\text { Colletotrichum coccodes, } \\
\text { Fusarium oxysporum }\end{array}$ & $\begin{array}{l}\text { Dávila et al. } \\
\text { (2016) }\end{array}$ \\
\hline & $\begin{array}{l}\text { Wilt disease of banana caused by } \\
\text { Fusarium oxysporum f. sp. cubense } \\
\text { (FOC) }\end{array}$ & Dewi et al. (2017) \\
\hline Streptomyces strain KX852460 & $\begin{array}{l}\text { Rhizoctonia solani AG-3 } \\
\text { KX852461 }\end{array}$ & $\begin{array}{l}\text { Ahsan et al. } \\
(2017)\end{array}$ \\
\hline Streptomyces $12-09-4$ and 12-09-11 & $\begin{array}{l}\text { Botrytis cinerea, Fusarium } \\
\text { oxysporum f. sp. cucumerinum }\end{array}$ & Wang et al. (2018) \\
\hline
\end{tabular}

the production of plant growth promoters and making the plant less susceptible to pathogenic invasion. They are efficient agent of reducing the symptoms that arise due to exposure to environmental stress (Shimizu 2011). Enhanced production of indole acetic acid (IAA) was mediated by Streptomyces sp. (isolated from Centella asiatica) and Nocardiopsis sp. (Dochhil et al. 2013; Shutsrirung et al. 2014; Gangwar et al. 2014). Experimental trials on cucumber indicate positive result as the isolates Actinoplanes campanulatus, Micromonospora chalcea, and Streptomyces spiralis enhanced plant growth and improved yield conditions (El-Tarabily et al. 2010). Other than auxin, auxin-like similarly functioning molecules named as pteridic acids $\mathrm{A}$ and $\mathrm{B}$ are found to be inducers of adventitious root proliferation in kidney bean plants at very minute concentrations of $1 \mathrm{mM}$ (Igarashi et al. 2002).

\subsubsection{Siderophores and Chitinases}

Chitin is a major fungal cell wall polysaccharide (the second most abundant polysaccharide in nature after cellulose) component and is the first line of defense of fungal cells. Actinobacteria antagonize the fungal cell by producing chitinases (an enzyme capable of hydrolyzing fungal cell wall) and break the glycosidic bonds in chitin and lead to the death of the pathogenic cell. Endophytic Kitasatosporia sp. 
Table 9.8 Antifungal compounds from bacterial origin and their common targets

\begin{tabular}{|c|c|c|}
\hline $\begin{array}{l}\text { Bacillomycin D (B. subtilis AU195), } \\
\text { bacillomycin and fengycin (B. } \\
\text { amyloliquefaciens FZB42), Zwittermicin } \\
\text { A (B. cereus } \text { UW85), geldanamycin ( } S \text {. } \\
\text { hygroscopicus var. geldanus), chaetomin } \\
\text { (Chaetomium globosum), gliotoxin ( } T \text {. } \\
\text { virens), 2,4-diacetylphloroglucinol } \\
\text { (Pseudomonas fluorescens } \text { F113) }\end{array}$ & $\begin{array}{l}\text { Aspergillus flavus, } \\
\text { Fusarium oxysporum, } \\
\text { Phytophthora medicaginis, } \\
\text { R. solani, P. ultimum, } \\
\text { Pyricularia oryzae }\end{array}$ & $\begin{array}{l}\text { DeBoer et al. } \\
\text { (1970), Shanahan } \\
\text { et al. (1992), Smith } \\
\text { et al. (1993), Moyne } \\
\text { et al. (2001), } \\
\text { Wilhite et al. } \\
\text { (2001), Koumoutsi } \\
\text { et al. (2004) and } \\
\text { Anitha Murugesan } \\
\text { (2005) }\end{array}$ \\
\hline $\begin{array}{l}\text { Pyrrolnitrin, pyoluteorin, pseudane } \\
\text { (Burkholderia cepacia, P. fluorescens } \\
\text { Pf-5), phenazines (P. fluorescens } 2-79 \\
\text { and 30-84) }\end{array}$ & $\begin{array}{l}\text { Damping off (Phytophthora } \\
\text { medicaginis, } P \text {. } \\
\text { aphanidermatum), damping } \\
\text { off and rice blast }(\text { R. solani, } \\
\text { Pyricularia oryzae, Pythium } \\
\text { ultimum), take-all } \\
\text { (Gaeumannomyces } \\
\text { graminis } \text { var. } \text { tritici) }\end{array}$ & $\begin{array}{l}\text { Howell and } \\
\text { Stipanovic (1980), } \\
\text { Homma et al. } \\
\text { (1989), Thomashow } \\
\text { et al. (2002) and } \\
\text { Smith et al. (1993) }\end{array}$ \\
\hline $\begin{array}{l}\text { Harpin proteins (Erwinia amylovora), } \\
\text { trade name: Harpin } \alpha \beta \text { (ProAct) }\end{array}$ & $\begin{array}{l}\text { Induction of systemic } \\
\text { acquired resistance (SAR) } \\
\text { and less susceptibility to } \\
\text { fungal and bacterial disease }\end{array}$ & Wei et al. (1992) \\
\hline $\begin{array}{l}\text { Strobilurin and oudemansin (members of } \\
\text { basidiomycete grows on dead wood) } \\
\text { Commercial synthetic analogues: } \\
\text { azoxystrobin and kresoxim-methyl }\end{array}$ & $\begin{array}{l}\text { Fungal pathogens (blockage } \\
\text { of mitochondrial } \\
\text { respirations by blocking of } \\
\text { ubiquinone receptor) }\end{array}$ & $\begin{array}{l}\text { Kraiczy et al. } \\
\text { (1996) }\end{array}$ \\
\hline $\begin{array}{l}\text { Mycosubtilin (B. subtilis BBG100), } \\
\text { iturin A (B. subtilis QST713), herbicolin } \\
\text { (Pantoea agglomerans C9-1), } \\
\text { xanthobaccin A (Lysobacter } \text { sp. strain } \\
\text { SB-K88), }\end{array}$ & $\begin{array}{l}\text { Damping off (Pythium } \\
\text { aphanidermatum, Botrytis } \\
\text { cinerea }), \text { root rots }(\text { R. } \\
\text { solani), fire blight }(\text { Erwinia } \\
\text { amylovora }), \text { damping off } \\
\text { (Aphanomyces cochlioides })\end{array}$ & $\begin{array}{l}\text { Sandra et al. (2001), } \\
\text { Kloepper et al. } \\
\text { (2004), Leclere } \\
\text { et al. (2005), Islam } \\
\text { et al. (2005) and } \\
\text { Paulitz and } \\
\text { Belanger (2001) }\end{array}$ \\
\hline
\end{tabular}

(isolate of Catharanthus roseus) and Kibdelosporangium sp. (isolate of Achillea fragrantissima) are reported to be chitinase producers (El-Shatoury et al. 2009; Mini Priya 2012). Actinoplanes missouriensis isolated from Lupinus sp., a member of Fabaceae family, produces chitinase causing hyphal cell lysis and reducing the conidial germination rate and protects the plant from pathogenic attack of Plectosporium tabacinum, the causal agent of lupin root rot in Egypt (El-Tarabily 2003; El-Tarabily and Sivasithamparam 2006). Siderophores are soluble, small, high-affinity iron carriers produced by bacterial or fungal members and are involved in the transportation of iron $\left(\mathrm{Fe}^{3+}\right)$ across the cell membrane. They have caught sudden attention due to their involvement in plant growth promotion as well as antagonistic ability against phytopathogens (Cao et al. 2005; Tan et al. 2006; Rungin et al. 2012). Endophytic actinobacteria from Aloe vera, Mentha arvensis, and Ocimum sanctum are known to be producers of hydroxymate type and catechol type of siderophores, and the isolate Saccharopolyspora $\mathrm{O} 9$ is known to be the potent inhibitor 
<smiles>CN(CC[C@H](N)CC(=O)NC1C=CC(n2ccc(N)nc2=O)OC1C(=O)O)C(=N)N</smiles>

Blasticidin S

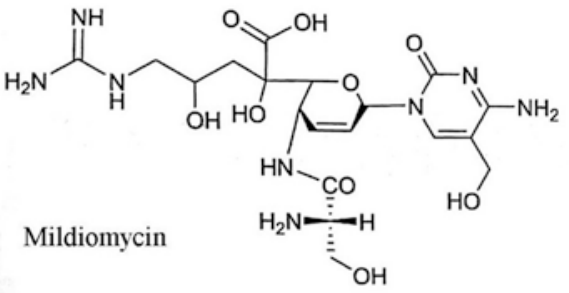<smiles>OCC1=CC(NC2CC(O)C(OC3CC(CO)C(O)C4OC3C4O)C2O)C(O)CC1(O)O</smiles>

Validamycin

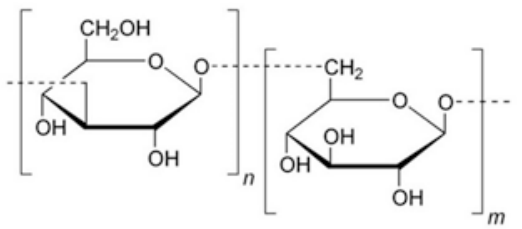

$\beta-1,3$

$\beta-1,6$

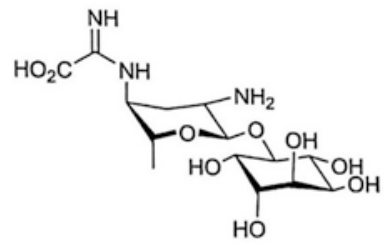

Kasugamycin

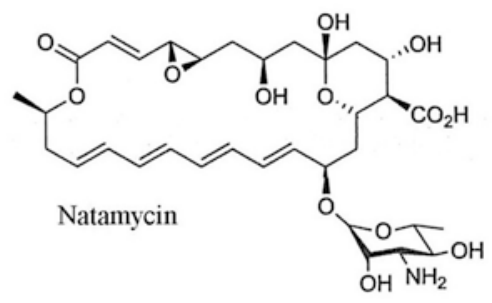

Laminaran/laminarin

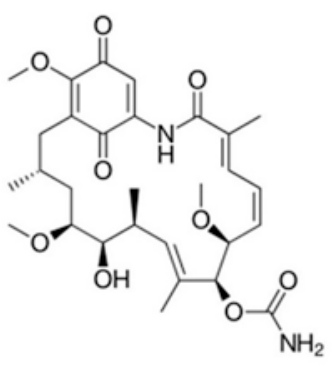

Geldanamycin

Fig. 9.6 Antibiotics and polysaccharides with plant protective ability 
of Alternaria brassicicola, Botrytis cinerea, and Fusarium oxysporum (Gangwar et al. 2014; El-Shatoury et al. 2009).

\subsubsection{Biocontrol Activity}

Endophytic isolates of Cucumis sativus (cucumber), identified as Actinoplanes campanulatus, Micromonospora chalcae, and Streptomyces spiralis, are reported to control the growth and development of damping off, crown rot, and root rot pathogen Pythium aphanidermatum. They are known to promote plant growth and to protect seedlings and mature plants. A novel bioactive compound identified as 6-prenylindole was isolated from endophytic Streptomyces sp. showing strong antifungal activity against a broad range of phytopathogens: Alternaria brassicicola and Fusarium oxysporum (Igarashi 2004). Another new prenylated indole derivative from endophytic actinobacterial source inhibited the growth of Colletotrichum orbiculare, Phytophthora capsici, Corynespora cassiicola, and Fusarium oxysporum (Zhang et al. 2014). Naphthomycins A and K isolated from Streptomyces sp. CS have antifungal activity against Penicillium avellaneum (Lu and Shen 2003, 2007). Biocontrol ability of fistupyrone has made it a useful tool to minimize the crop loss of Brassica due to black leaf spot disease caused by Alternaria brassicicola (Igarashi 2004). Interest on actinomycetes of endophytic origin as an alternative tool for antifungal agent is increasing day by day (Table 9.9).

\subsection{Plant Extracts as the Prime Source for Antifungals}

Since the beginning of human civilization, whenever human race has faced any turbulence in its path of existence, they have rushed to their green friends, trees, for the ultimate solution. Search for bioactive products of medical importance has been a thirst area from time immemorial. Whether it is a concern of human or plant health, trees have given answers in all aspects. In the recent past, phytopathogenic infection has pushed the agricultural productive parameters to a real challenge, and plant extracts in its crude and purified form are applied as biocontrol methods (Table 9.10). The existing synthetic chemicals are facing problem of immediate or delayed drug resistance and also issues of nephrotoxicity (the gold standard; amphotericin B), biomagnification, or quality assurance of the food products and thus are inconsistent in their business (Goa and Barradell 1995; Cuenca-Estrella et al. 2000). So green plant extracts are the novel, safest, and the best effective treatment tool in this arena. Plants are mysterious in their chemical nature and in respect to their secondary metabolite production. The faith is consistent on green plants due to the fact that plants protect themselves from fungal or bacterial diseases specially for the taxa that occur in marshy shady or water-logged or stress conditions (Gurgel et al. 2005). So the search is primarily made on the wild native taxa or invasive species that have higher potential of antimicrobial production. The knowledge of ethnobotany comes in this context, and tribal people are imitated for the gathering of crude knowledge. The problem of fungal pathogenesis is mainly faced by plants of economic importance, that is, cash crops. A single event of pathogenic attack can 
Table 9.9 Endophytic actinomycetes as antifungal agents

\begin{tabular}{|c|c|c|c|}
\hline Actinomycetes & Host plant & Antifungal against & References \\
\hline Streptomyces sp. & Rhododendron & $\begin{array}{l}\text { Phytophthora } \\
\text { cinnamomi, } \\
\text { Pestalotiopsis } \\
\text { sydowiana }\end{array}$ & $\begin{array}{l}\text { Shimizu et al. } \\
(2000)\end{array}$ \\
\hline $\begin{array}{l}\text { Streptomyces NRRL } \\
30562\end{array}$ & $\begin{array}{l}\text { Snake vine medicinal } \\
\text { plant (Kennedia } \\
\text { nigriscans) }\end{array}$ & $\begin{array}{l}\text { Pythium ultimum, } \\
\text { Rhizoctonia solani, } \\
\text { Phytophthora } \\
\text { cinnamomi, Geotrichum } \\
\text { candidum, Sclerotinia } \\
\text { sclerotiorum }\end{array}$ & $\begin{array}{l}\text { Castillo et al. } \\
\text { (2002), (2006) }\end{array}$ \\
\hline Streptomyces sp. & Allium fistulosum & $\begin{array}{l}\text { Alternaria brassicicola } \\
\text { on Chinese cabbage } \\
\text { seedlings }\end{array}$ & $\begin{array}{l}\text { Igarashi et al. } \\
\text { (2002) }\end{array}$ \\
\hline Streptomyces sp. AOK-30 & $\begin{array}{l}\text { Mountain laurel } \\
\text { (Kalmia latifolia) }\end{array}$ & Pestalotia rhododendri & $\begin{array}{l}\text { Nisimura et al. } \\
(2002)\end{array}$ \\
\hline Streptomyces sp. CS & Maytenus hookeri & $\begin{array}{l}\text { Penicillium avellaneum } \\
\text { UC-4376 }\end{array}$ & $\begin{array}{l}\text { Lu and Shen } \\
(2003),(2007)\end{array}$ \\
\hline $\begin{array}{l}\text { Streptomyces sp. } \\
\text { TP-A0595, Streptomyces } \\
\text { sp. TP-A0569 }\end{array}$ & Allium tuberosum & Alternaria brassicicola & Igarashi (2004) \\
\hline $\begin{array}{l}\text { Streptomyces sp. } \\
\text { MSU-2110 }\end{array}$ & Monstera sp. & $\begin{array}{l}\text { P. ultimum, } \\
\text { Phytophthora } \\
\text { cinnamomi, Geotrichum } \\
\text { candidum, F. solani, } \\
\text { Rhizoctonia solani }\end{array}$ & $\begin{array}{l}\text { Ezra et al. } \\
(2004 a, b)\end{array}$ \\
\hline $\begin{array}{l}\text { Streptomyces } \\
\text { griseofuscus, } \\
\text { Streptomyces } \\
\text { hygroscopicus, } \\
\text { Streptomyces } \\
\text { globisporus, } \\
\text { Streptomyces aureus, } \\
\text { Streptomyces albosporus }\end{array}$ & Rice (Oryza sativa) & $\begin{array}{l}\text { Magnaporthe grisea, } \\
\text { Rhizoctonia solani, } \\
\text { Xanthomonas oryzae, } \\
\text { Fusarium moniliforme }\end{array}$ & $\begin{array}{l}\text { Tian et al. } \\
(2004)\end{array}$ \\
\hline $\begin{array}{l}\text { Streptomyces } \\
\text { aureofaciens CMU } \\
\text { Ac130, Streptomyces sp. } \\
\text { Tc022 }\end{array}$ & Zingiber officinale & $\begin{array}{l}\text { Fusarium oxysporum, } \\
\text { Colletotrichum musae }\end{array}$ & $\begin{array}{l}\text { Taechowisan } \\
\text { et al. (2006), } \\
(2007)\end{array}$ \\
\hline $\begin{array}{l}\text { Streptomyces sp., } \\
\text { Streptoverticillium sp., } \\
\text { Streptosporangium sp. }\end{array}$ & Musa paradisiaca & $\begin{array}{l}\text { Fusarium sp. wilt } \\
\text { pathogen }\end{array}$ & $\begin{array}{l}\text { Cao et al. } \\
(2005)\end{array}$ \\
\hline
\end{tabular}


Table 9.9 (continued)

\begin{tabular}{|c|c|c|c|}
\hline Actinomycetes & Host plant & Antifungal against & References \\
\hline $\begin{array}{l}\text { Streptomyces } \\
\text { fulvoviolaceus, } \\
\text { Streptomyces caelestis, } \\
\text { Streptomyces coelicolor }\end{array}$ & $\begin{array}{l}\text { Thottea grandiflora, } \\
\text { Mapania spp., } \\
\text { Polyalthia spp. }\end{array}$ & $\begin{array}{l}\text { Fusarium solani, } \\
\text { Aspergillus fumigatus, } \\
\text { Mycosphaerella } \\
\text { fijiensis, Pythium } \\
\text { ultimum, } \\
\text { Sclerotinia } \\
\text { sclerotiorum, } \\
\text { Rhizoctonia solani, } \\
\text { Phytophthora } \\
\text { erythroseptica }\end{array}$ & $\begin{array}{l}\text { Zin et al. } \\
(2007)\end{array}$ \\
\hline $\begin{array}{l}\text { Microbispora sp., } \\
\text { Nonomurae sp., } \\
\text { Streptomyces sp. }\end{array}$ & $\begin{array}{l}\text { Solanum } \\
\text { lycopersicum }\end{array}$ & $\begin{array}{l}\text { Rhizoctonia solani, } \\
\text { Pythium irregulare, A. } \\
\text { solani, P. parasitica }\end{array}$ & $\begin{array}{l}\text { Inderiati and } \\
\text { Franco (2008) }\end{array}$ \\
\hline $\begin{array}{l}\text { Streptomyces sp., } \\
\text { Nocardia } \text { sp., } \\
\text { Streptosporangium sp., } \\
\text { Streptoverticillium sp. }\end{array}$ & Azadirachta indica & $\begin{array}{l}\text { Pythium oligandrum, } \\
\text { Pythium ultimum, } \\
\text { Pythium } \\
\text { aphanidermatum, } \\
\text { Phytophthora cypogea, } \\
\text { Phytophthora cactorum, } \\
\text { Phytophthora infestans }\end{array}$ & $\begin{array}{l}\text { Verma et al. } \\
(2009)\end{array}$ \\
\hline $\begin{array}{l}\text { Promicromonospora } \\
\text { cymbopogonis, } \\
\text { Nonomuraea roseola, } \\
\text { Micromonospora } \\
\text { chokoriensis, } \\
\text { Streptomyces } \\
\text { ochraceiscleroticus, } S . \\
\text { aurantiacus, } S . \\
\text { griseocameus, } \text { S. } \\
\text { chryseus, } \text { S. albogriseolus }\end{array}$ & $\begin{array}{l}\text { Juncus effusus L., } \\
\text { Ainsliaea henryi, } \\
\text { Stellera } \\
\text { chamaejasme, Salvia } \\
\text { miltiorrhiza, } \\
\text { Lysimachia fortune, } \\
\text { Senecio declouxii, } \\
\text { Potentilla discolor, } \\
\text { Achyranthes aspera, } \\
\text { Cynanchum } \\
\text { auriculatum }\end{array}$ & $\begin{array}{l}\text { Verticillium dahliae, } \\
\text { Fusarium oxysporum } \mathrm{f} . \\
\text { sp. vasinfectum, } \\
\text { Aspergillus niger, } \\
\text { Fusarium oxysporum } \mathrm{f} . \\
\text { sp. niveum, } \\
\text { Colletotrichum } \\
\text { orbiculare, Fusarium } \\
\text { graminearum, } \\
\text { Exserohilum turcicum, } \\
\text { Curvularia lunata, } \\
\text { Botrytis cinerea }\end{array}$ & $\begin{array}{l}\text { Zhao et al. } \\
(2011)\end{array}$ \\
\hline $\begin{array}{l}\text { Streptomyces sp. } \\
\text { Hedaya-48 }\end{array}$ & Aplysina fistularis & F. oxysporum & $\begin{array}{l}\text { El-Gendy and } \\
\text { El-Bondkly } \\
(2010) \\
\end{array}$ \\
\hline $\begin{array}{l}\text { Actinoplanes } \\
\text { campanulatus, } \\
\text { Micromonospora } \\
\text { chalcea, Streptomyces } \\
\text { spiralis }\end{array}$ & $\begin{array}{l}\text { Cucumber (Cucumis } \\
\text { sativa) }\end{array}$ & $\begin{array}{l}\text { Pythium } \\
\text { aphanidermatum }\end{array}$ & $\begin{array}{l}\text { El-Tarabily } \\
\text { et al. (2010) }\end{array}$ \\
\hline $\begin{array}{l}\mathrm{Cr}-12 \text { and } \mathrm{Cr}-20 \\
\text { unidentified isolates }\end{array}$ & Catharanthus roseus & $\begin{array}{l}\text { Curvularia lunata, } \\
\text { Fusarium oxysporum, } \\
\text { Fusarium solani, } \\
\text { Rhizoctonia solani }\end{array}$ & $\begin{array}{l}\text { Kafur and Khan } \\
\text { (2011) }\end{array}$ \\
\hline Streptomyces coelicolor & $\begin{array}{l}\text { Rhizophora } \\
\text { apiculata, Avicennia } \\
\text { marina }\end{array}$ & $\begin{array}{l}\text { A. niger, A. flavus, } \\
\text { Penicillium sp., A. } \\
\text { fumigatus }\end{array}$ & $\begin{array}{l}\text { Gayathri and } \\
\text { Muralikrishnan } \\
\text { (2013) }\end{array}$ \\
\hline
\end{tabular}


Table 9.9 (continued)

\begin{tabular}{|c|c|c|c|}
\hline Actinomycetes & Host plant & Antifungal against & References \\
\hline Streptomyces sp. 16R3B & Zea mays & $\begin{array}{l}\text { P. aphanidermatum, } \\
\text { causal agent of damping } \\
\text { off in cucumber } \\
(\text { Cucumis sativa })\end{array}$ & $\begin{array}{l}\text { Costa et al. } \\
(2013)\end{array}$ \\
\hline $\begin{array}{l}\text { Streptomyces sp. } \\
\text { neau-D50 }\end{array}$ & $\begin{array}{l}\text { Soybean (Glycine } \\
\max \text { ) }\end{array}$ & $\begin{array}{l}\text { Phytophthora capsici, } \\
\text { Corynespora cassiicola, } \\
\text { Fusarium oxysporum, } \\
\text { Colletotrichum } \\
\text { orbiculare }\end{array}$ & $\begin{array}{l}\text { Zhang et al. } \\
\text { (2014) }\end{array}$ \\
\hline $\begin{array}{l}\text { Streptomyces cinereus } \\
\text { AR16 }\end{array}$ & Emblica officinalis & $\begin{array}{l}\text { Fusarium oxysporum, } \\
\text { Rhizoctonia solani, } \\
\text { Aspergillus niger, } \\
\text { Alternaria brassicicola, } \\
\text { Phytophthora dresclea }\end{array}$ & $\begin{array}{l}\text { Gangwar et al. } \\
\text { (2015) }\end{array}$ \\
\hline $\begin{array}{l}\text { Streptomyces } \mathrm{sp} . \\
\text { Leifsonia xyli, } \\
\text { Microbacterium } \mathrm{sp} . \\
\text { Streptomyces } \mathrm{sp} . \\
\text { Brevibacterium } \text { sp. }\end{array}$ & $\begin{array}{l}\text { Mirabilis jalapa, } \\
\text { Clerodendrum } \\
\text { colebrookianum }\end{array}$ & $\begin{array}{l}\text { Rhizoctonia solani, } \\
\text { Fusarium graminearum, } \\
\text { Fusarium oxysporum, } \\
\text { Fusarium proliferatum, } \\
\text { Fusarium oxysporum } \mathrm{f} \text {. } \\
\text { sp. ciceris, } \\
\text { Colletotrichum capsici }\end{array}$ & $\begin{array}{l}\text { Passari et al. } \\
\text { (2015) }\end{array}$ \\
\hline Streptomyces sp. & Schima wallichii & $\begin{array}{l}\text { Colletotrichum sp., } \\
\text { Alternaria } \mathrm{sp} ., \\
\text { F. oxysporum } \mathrm{f} . \mathrm{sp} . \\
\text { ciceris, F. proliferatum } \\
\text { F. culmorum, F. } \\
\text { graminearum }\end{array}$ & $\begin{array}{l}\text { Passari et al. } \\
(2016)\end{array}$ \\
\hline $\begin{array}{l}\text { Melia toosendan } \\
\text { (chinaberry) }\end{array}$ & $\begin{array}{l}\text { Rhodococcus sp., } \\
\text { Tomitella sp. }\end{array}$ & $\begin{array}{l}\text { Colletotrichum } \\
\text { orbiculare, Fusarium } \\
\text { oxysporum, Alternaria } \\
\text { solani, Magnaporthe } \\
\text { grisea, Curvularia } \\
\text { lunata, Gibberella } \\
\text { saubinetii }\end{array}$ & $\begin{array}{l}\text { Zhao et al. } \\
\text { (2018) }\end{array}$ \\
\hline $\begin{array}{l}\text { Streptomyces levis NBRC } \\
15423(\mathrm{~T}), \text { Streptomyces } \\
\text { gilvifuscus } \mathrm{T} 113(\mathrm{~T}), \\
\text { Micromonospora } \\
\text { olivasterospora } \mathrm{DSM} \\
\text { 43868(T), Actinomadura } \\
\text { geliboluensis A8036(T), } \\
\text { Streptomyces } \\
\text { djakartensis } \mathrm{NBRC} \\
15409(\mathrm{~T}), \text { Streptomyces } \\
\text { griseoaurantiacus } \mathrm{NBRC} \\
15440(\mathrm{~T}), \text { Nocardiopsis } \\
\text { dassonvillei } \mathrm{NBRC} \\
13392(\mathrm{~T})\end{array}$ & Camellia sinensis & $\begin{array}{l}\text { Magnaporthe oryzae, } \\
\text { Fusarium graminearum, } \\
\text { F. oxysporum f. sp. } \\
\text { lycopersici, F. } \\
\text { oxysporum f. sp. } \\
\text { cubense, F. } \\
\text { verticillioides, } \\
\text { Colletotrichum sp., } \\
\text { Pestalotiopsis sp., } \\
\text { Diaporthe sp., Xylaria } \\
\text { sp. }\end{array}$ & $\begin{array}{l}\text { Shan et al. } \\
(2018)\end{array}$ \\
\hline
\end{tabular}


Table 9.10 Bioactive products with their common sources and targets

\begin{tabular}{|c|c|c|c|}
\hline Bioactive product & Source & Effective against & References \\
\hline Carvone & $\begin{array}{l}\text { Dill and caraway } \\
\text { seed }\end{array}$ & $\begin{array}{l}\text { Inhibit the growth of } \\
\text { storage pathogen }\end{array}$ & $\begin{array}{l}\text { Moezelaar } \\
\text { et al. } \\
\text { (1999) }\end{array}$ \\
\hline $\begin{array}{l}\text { Gamma aminobutyric acid } \\
\text { (GABA) }\end{array}$ & $\begin{array}{l}\text { Any type of plant } \\
\text { and animal source }\end{array}$ & $\begin{array}{l}\text { Prevent powdery } \\
\text { mildew on grapes, } \\
\text { brown rot and shot } \\
\text { hole of stone fruit; } \\
\text { enhances growth of } \\
\text { almond, broccoli, } \\
\text { onions }\end{array}$ & $\begin{array}{l}\text { Copping } \\
(2004)\end{array}$ \\
\hline $\begin{array}{l}\text { Cinnamaldehyde from cinnamon } \\
\text { leaf essential oil (mixture of } \\
\alpha \text {-methyl cinnamaldehyde, } \\
\text { (E)-2-methylcinnamic acid, } \\
\text { eugenol, isoeugenol, citral, } \\
\text { geraniol oil), trade name: Vertigo } \\
\text { and Cinnacure }\end{array}$ & $\begin{array}{l}\text { Cinnamomum } \\
\text { osmophloeum } \\
\text { Alternate source: } \\
\text { seeds of the weed } \\
\text { Cassia obtusifolia }\end{array}$ & $\begin{array}{l}\text { Dry bubble (caused } \\
\text { by Verticillium } \\
\text { fungicola), dollar } \\
\text { spot (Sclerotinia } \\
\text { homoeocarpa), pitch } \\
\text { canker (Fusarium } \\
\text { moniliforme var. } \\
\text { subglutinans), wood } \\
\text { rot fungi (Coriolus } \\
\text { versicolor and } \\
\text { Laetiporus } \\
\text { sulphureus, } \\
\text { Aspergillus } \\
\text { fumigatus and } \\
\text { Trichophyton } \\
\text { rubrum) }\end{array}$ & $\begin{array}{l}\text { Copping } \\
\text { (2004), } \\
\text { Wang et al. } \\
\text { (2005), } \\
\text { Cheng et al. } \\
\text { (2008) and } \\
\text { Khan and } \\
\text { Ahmad } \\
\text { (2011) }\end{array}$ \\
\hline Jojoba oil (vegetable oil) & $\begin{array}{l}\text { Simmondsia } \\
\text { chinensis } \\
\text { (Simmondsiaceae) }\end{array}$ & $\begin{array}{l}\text { Powdery mildew for } \\
\text { ornamental plants } \\
\text { and grapes and } \\
\text { applied as ground } \\
\text { spray }\end{array}$ & $\begin{array}{l}\text { Copping } \\
(2004)\end{array}$ \\
\hline $\begin{array}{l}\text { Milsana (ethanolic extracts of } \\
\text { plant) }\end{array}$ & $\begin{array}{l}\text { Reynoutria } \\
\text { sachalinensis } \\
\text { (Polygonaceae) }\end{array}$ & $\begin{array}{l}\text { Powdery mildew of } \\
\text { wheat and grape } \\
\text { (Uncinula necator, } \\
\text { Sphaerotheca } \\
\text { fuliginea) by induced } \\
\text { resistance, used as a } \\
\text { spray }\end{array}$ & $\begin{array}{l}\text { Copping } \\
(2004)\end{array}$ \\
\hline Pink plume poppy blood root & $\begin{array}{l}\text { Macleaya cordata } \\
\text { Sanguinaria } \\
\text { Canadensis } \\
\text { (Papaveraceae) }\end{array}$ & $\begin{array}{l}\text { Alkaloids; } \\
\text { sanguinarine } \\
\text { effective against } \\
\text { Rhizoctonia solani } \\
\text { by systemic acquired } \\
\text { resistance (SAR)- } \\
\text { mediated } \\
\text { accumulation of } \\
\text { endogenous } \\
\text { phenolics }\end{array}$ & $\begin{array}{l}\text { Liu et al. } \\
(2009 a, b)\end{array}$ \\
\hline
\end{tabular}


Table 9.10 (continued)

\begin{tabular}{|c|c|c|c|c|}
\hline \multicolumn{2}{|c|}{ Bioactive product } & Source & Effective against & References \\
\hline \multicolumn{2}{|l|}{ Sporan } & $\begin{array}{l}\text { Rosemary oil } \\
\text { (Rosmarinus } \\
\text { officinalis) }\end{array}$ & Botrytis cinerea & $\begin{array}{l}\text { Zaker } \\
(2016)\end{array}$ \\
\hline \multicolumn{2}{|l|}{ Promax } & $\begin{array}{l}\text { Thyme oil } \\
\text { (Thymus vulgaris) }\end{array}$ & Botrytis cinerea & $\begin{array}{l}\text { Zaker } \\
(2016)\end{array}$ \\
\hline \multicolumn{2}{|l|}{ Trilogy } & $\begin{array}{l}\text { Neem oil } \\
\text { (Azadirachta } \\
\text { indica) }\end{array}$ & $\begin{array}{l}\text { F. oxysporum, } R \text {. } \\
\text { solani }\end{array}$ & $\begin{array}{l}\text { Zaker } \\
(2016)\end{array}$ \\
\hline \multicolumn{2}{|l|}{ GC-3 $3^{\mathrm{TM}}$} & $\begin{array}{l}\text { Cottonseed } \\
\text { (Gossypium } \\
\text { hirsutum) and } \\
\text { garlic (Allium } \\
\text { sativum) }\end{array}$ & - & $\begin{array}{l}\text { Zaker } \\
(2016)\end{array}$ \\
\hline \multirow[t]{3}{*}{ Fatty Acids } & $\begin{array}{l}\text { Polyacetylenic } \\
\text { acids, octadeca- } \\
9,11,13 \text {-triynoic } \\
\text { acid, trans-octadec- } \\
\text { 13-ene- } 9,11- \\
\text { diynoic acid }\end{array}$ & Prunella vulgaris & $\begin{array}{l}\text { M. oryzae, } R \text {. solani, } \\
\text { P. infestans, } S \text {. } \\
\text { sclerotiorum, } F \text {. } \\
\text { oxysporum, and } P \text {. } \\
\text { capsici. Inhibits rice } \\
\text { blast, tomato late } \\
\text { blight, wheat leaf } \\
\text { rust, and red pepper } \\
\text { anthracnose }\end{array}$ & $\begin{array}{l}\text { Yoon et al. } \\
(2010)\end{array}$ \\
\hline & Lipopeptides & $\begin{array}{l}\text { Bacillus XT1 } \\
\text { CECT } 8661\end{array}$ & Botrytis cinerea & $\begin{array}{l}\text { Toral et al. } \\
(2018)\end{array}$ \\
\hline & $\begin{array}{l}\text { Ginger oleoresin } \\
(\mathrm{GO})\end{array}$ & Ginger & $\begin{array}{l}\text { Pestalotiopsis } \\
\text { microspora; } \\
\text { dominant pathogenic } \\
\text { fungi causing rotten } \\
\text { disease in harvested } \\
\text { Chinese olive } \\
\text { (Canarium album } \\
\text { Lour.) fruits }\end{array}$ & $\begin{array}{l}\text { Chen et al. } \\
(2018)\end{array}$ \\
\hline
\end{tabular}


Table 9.10 (continued)

\begin{tabular}{|c|c|c|c|c|}
\hline \multicolumn{2}{|c|}{ Bioactive product } & \multirow{2}{*}{$\begin{array}{l}\text { Source } \\
\text { Veratrum taliense }\end{array}$} & \multirow{2}{*}{$\begin{array}{l}\text { Effective against } \\
\text { Phytophthora capsici }\end{array}$} & \multirow{2}{*}{\begin{tabular}{|l|} 
References \\
$\begin{array}{l}\text { Zhou et al. } \\
(2003)\end{array}$
\end{tabular}} \\
\hline Alkaloids & $\begin{array}{l}\text { Steroidal alkaloids; } \\
\text { verazine type } \\
\text { (veramitaline, } \\
\text { stenophylline B, } \\
\text { veramiline) and } \\
\text { jerveratrum type } \\
\text { (jervine) }\end{array}$ & & & \\
\hline & $\begin{array}{l}\text { D-Calycanthin, } \\
\text { L-folicanthine }\end{array}$ & $\begin{array}{l}\text { Chimonanthus } \\
\text { praecox (from } \\
\text { seeds) }\end{array}$ & $\begin{array}{l}\text { Exserohilum } \\
\text { turcicum, B. maydis, } \\
\text { A. solani, } S \text {. } \\
\text { sderotiorum, F. } \\
\text { oxysporum }\end{array}$ & $\begin{array}{l}\text { Zhang et al. } \\
(2006)\end{array}$ \\
\hline & Securinine & $\begin{array}{l}\text { Phyllanthus } \\
\text { amarus }\end{array}$ & $\begin{array}{l}\text { Alternaria alternate, } \\
\text { A. brassicae, A. } \\
\text { brassicicola, } \\
\text { Curvularia lunata, } \\
\text { C. maculans, } \text { C. } \\
\text { pallenscens, } \\
\text { C. musae, } \\
\text { Helminthosporium } \\
\text { echinoclova, } \\
\text { H. spiciferum }\end{array}$ & $\begin{array}{l}\text { Singh et al. } \\
(2008)\end{array}$ \\
\hline & $\begin{array}{l}\text { Pipernonaline, a } \\
\text { piperidine alkaloid }\end{array}$ & Piper longum & $\begin{array}{l}\text { M. oryzae, } R . \text { solani, } \\
\text { B. cinerea, } P . \\
\text { infestans, } P . \\
\text { recondite, } B . \\
\text { graminis }\end{array}$ & $\begin{array}{l}\text { Yoon et al. } \\
(2013)\end{array}$ \\
\hline \multirow[t]{3}{*}{ Glycosides } & $\begin{array}{l}\text { Hemoiedemosides } \\
\text { A, B (sulfated } \\
\text { triterpene), }\end{array}$ & $\begin{array}{l}\text { Patagonian sea } \\
\text { cucumber } \\
\text { (Hemoiedema } \\
\text { spectabilis) }\end{array}$ & $\begin{array}{l}\text { Cladosporium } \\
\text { cucumerinum }\end{array}$ & $\begin{array}{l}\text { Chludil } \\
\text { et al. } \\
(2002)\end{array}$ \\
\hline & $\begin{array}{l}\text { Triterpenic } \\
\text { saponins, }\end{array}$ & $\begin{array}{l}\text { Sapindus } \\
\text { mukorossi, } \\
\text { Diploknema } \\
\text { butyracea }\end{array}$ & & $\begin{array}{l}\text { Saha et al. } \\
\text { (2010) }\end{array}$ \\
\hline & $\begin{array}{l}\text { Pregnane (caudatin } \\
\text { glycosides) }\end{array}$ & $\begin{array}{l}\text { Cynanchum } \\
\text { wilfordii (roots) }\end{array}$ & $\begin{array}{l}\text { Barley powdery } \\
\text { mildews and } \\
\text { strawberry powdery } \\
\text { mildew } \\
\text { (Sphaerotheca } \\
\text { humuli) }\end{array}$ & $\begin{array}{l}\text { Yoon et al. } \\
(2011)\end{array}$ \\
\hline
\end{tabular}

affect seriously the demand and supply ratio; thus the sustainability is lost, and restoring the good health of crops is a basic need of agricultural sectors but in an efficient way not hampering the soil health, ecosystem characters, and human health and also should be budget friendly. The search is strictly focused on plants of ethnomedicinal importance as history indicates the ability of medicinal plant extracts in human and animal mycoses and antifungal ability (Mathias-Mundy and McCorkle 
1995). The statistics of the World Health Organization (WHO) states that $80 \%$ of the worlds' population in underdeveloped or developing countries depend on plants of ethnomedicinal importance for their primary healthcare issues.

\subsubsection{Antifungal Properties of Secondary Metabolites of Plants}

Secondary metabolites are plants' best weapon against phytopathogenic invasion. Several plant extracts have been assessed for their antifungal activity against a variety of phytopathogens of serious agricultural threats (Table 9.11). The metabolites are divided into terpenoids, saponins, phenolic compounds, flavones, flavonoids, flavonols, alkaloids, and coumarins (Table 9.12). Plant extracts are primarily tested for antifungal efficacy and further are purified by solvent extraction and chromatographic procedures leading to discovery of new antifungal agents. Terpenoids, also called as isoprenoids (under the chemical subclass of prenyllipids), are known to be the oldest group of widespread molecular compounds produced by plants. Scher et al. (2004) reported a variety of six sesquiterpenes of antifungal importance against the causal organisms of bunch rot (Botrytis cinerea) on grapes, scab of cucurbits (Cladosporium cucumerinum), potato blight (Phytophthora infestans), rice blast (Pyricularia oryzae), and blotch of wheat (Septoria tritici). Sesquiterpene isolated from Polygonum punctatum (dotted knotweed of knotweed family Polygonaceae) named after the chemical polygodial is an effective control agent of Zygosaccharomyces bailii (a common food spoilage yeast). Scab of cucurbits is a common and devastating fungal pathogenic disease in agricultural fields, and this disease is to some extent prevented by the use of clerodane diterpenes extracted from Detarium microcarpum, a plant of Leguminosae family (Cavin et al. 2006). Skaltsa (2000) reported fungi inhibitory (Cunninghamella echinulata) activity of costunolide and eudesmane derivatives isolated from Centaurea plants. Other than terpenes, saponins (triterpene ad steroidal saponins) are also effective antifungals reported from plant sources. Tea is one of the most vital cash crops in terms of foreign money earning and the most popular beverage having antioxidative properties. Pathogenic infection by Pestalotia longiseta causes a huge loss of tea production. Nagata et al. in the year 1985 isolated triterpenoid saponins camelids I and II from the leaves of Camellia japonica (Japanese camellia) that inhibited the tea pathogen P. longiseta. Cucurbitacins I, A, B, Q, and E isolated from cucurbitacins (Ecballium elaterium) have antifungal activity against Botrytis cinerea (Har-Nun and Meyer 1990). Phenolics are odorous compounds having antifungal compounds and are also responsible for the plant pigment production. Phenolics cover a large number of chemical compounds, for example, alkylated phenols, anthraquinones, coumarins, phenolic acid, phenols, phenylpropanoids, quinines, xanthones, hydroxycinnamic acid, p-coumaric acid, ferulic acid, and chlorogenic acid. Phenol derivatives like crassinervic acid ( $P$. crassinervium), aduncumene (P. aduncum), hostmaniane (P. hostamannianum), and gaudichaudanic acid (P. gaudichaudianum) are effective against strawberry blossom blight pathogen Cladosporium cladosporioides (Lago et al. 2004). 3-Acetyl-4-acetoxyacetophenone showed antifungal activity against 
Table 9.11 Bioactive phytochemicals against common plant diseases of crop plants

\begin{tabular}{|c|c|c|}
\hline Name of the disease & $\begin{array}{l}\text { Plant taxa and chemical class of the } \\
\text { compound }\end{array}$ & References \\
\hline $\begin{array}{l}\text { Scab of cucumber } \\
\text { (Colletotrichum } \\
\text { cucumerinum) }\end{array}$ & $\begin{array}{l}\text { Napthoxirenes from bark of Sesamum } \\
\text { angolense of Pedaliaceae family, xanthone } \\
\text { from roots of Polygala nicaeensis } \\
\text { (Polygonaceae), sakurasosaponin from } \\
\text { leaves of Rapanea melanophloeos, } \\
\text { 5-methylcoumarins, mutisicoumarones C } \\
\text { and D from Mutisia friesiana } \\
\text { (Asteraceae), mollugenol A from Mollugo } \\
\text { pentaphylla (Molluginaceae), flavone and } \\
\text { flavonol of Helichrysum decumbens } \\
\text { (Asteraceae), triterpenoid saponin from } \\
\text { roots of Dolichos kilimandscharicus } \\
\text { (Leguminosae), Clerodane diterpene from } \\
\text { Detarium microcarpum, E-triticine, } \\
\text { P-triticine, puroindoline from Triticum } \\
\text { aestivum (Poaceae) }\end{array}$ & $\begin{array}{l}\text { Spendley et al. } \\
\text { (1982), Potterat et al. } \\
\text { (1987), Martson et al. } \\
\text { (1988), Marston et al. } \\
\text { (1993), Viturro et al. } \\
\text { (2004), Cavin et al. } \\
\text { (2006a), and } \\
\text { Dhatwalia et al. } \\
\text { (2009) }\end{array}$ \\
\hline $\begin{array}{l}\text { Disease of woody plant } \\
\text { (Melampsora medusae) }\end{array}$ & $\begin{array}{l}\text { Pinocembrin from leaves of Populus } \\
\text { deltoides (Salicaceae) }\end{array}$ & $\begin{array}{l}\text { Shain and Miller } \\
(1982), \text { Hoof et al. } \\
(2008)\end{array}$ \\
\hline $\begin{array}{l}\text { Cladosporium fruit and } \\
\text { leaf rot and bitter root } \\
\text { (Cladosporium } \\
\text { gloeosporioides) }\end{array}$ & $\begin{array}{l}\text { Long-chain alcohol from peels of young } \\
\text { fruit of Persea americana from Lauraceae, } \\
\text { methylripariochromene A from roots of } \\
\text { Eupatorium riparium (Asteraceae) }\end{array}$ & $\begin{array}{l}\text { Prusky et al. (1983), } \\
\text { Ratnayake Bandara } \\
\text { et al. (1992) }\end{array}$ \\
\hline $\begin{array}{l}\text { Pine needle pathogen } \\
\text { (Dothistroma pini) }\end{array}$ & $\begin{array}{l}\text { Stearic acid from needles of Pinus radiata } \\
\text { (Pinaceae) }\end{array}$ & Franich et al. (1983) \\
\hline $\begin{array}{l}\text { Pathogen of corn, } \\
\text { sorghum, apple } \\
\text { (Helminthosporium } \\
\text { carbonum) }\end{array}$ & $\begin{array}{l}\text { Luteone and wighteone from leaf surface } \\
\text { of Lupinus albus (Leguminosae) }\end{array}$ & Ingham et al. (1983) \\
\hline $\begin{array}{l}\text { Black and brown spot of } \\
\text { banana (Colletotrichum } \\
\text { musae) }\end{array}$ & $\begin{array}{l}\text { Dopamine from unripe banana fruit (Musa } \\
\text { sp.) }\end{array}$ & $\begin{array}{l}\text { Muirhead and } \\
\text { Deverall (1984) }\end{array}$ \\
\hline $\begin{array}{l}\text { Powdery mildew of } \\
\text { grains (Erysiphe } \\
\text { graminis) }\end{array}$ & $\begin{array}{l}\text { Gramine from leaves of Hordeum vulgare } \\
\text { (Poaceae) }\end{array}$ & $\begin{array}{l}\text { Wippich and Wink } \\
\text { (1985) }\end{array}$ \\
\hline $\begin{array}{l}\text { Leaf spot, rots, and } \\
\text { blights (Alternaria } \\
\text { alternata), disease of } \\
\text { cereal (Penicillium } \\
\text { verrucosum) }\end{array}$ & $\begin{array}{l}\text { Alizarin and emodin from root of Rubia } \\
\text { tinctorum of Rubiaceae, alkylated phenols } \\
\text { of peel and pulp of Mangifera indica } \\
\text { (Anacardiaceae) }\end{array}$ & $\begin{array}{l}\text { Cojocaru et al. } \\
\text { (1986), Manojlovic } \\
\text { et al. (2005) }\end{array}$ \\
\hline $\begin{array}{l}\text { Maize rot (Fusarium } \\
\text { moniliforme), epidemic } \\
\text { outbreak of glume and } \\
\text { kernel discoloration } \\
\text { (Curvularia lunata) }\end{array}$ & $\begin{array}{l}\text { Flavan-4-ols of root bark of Sorghum } \\
\text { cultivars of Poaceae }\end{array}$ & $\begin{array}{l}\text { Jambunathan et al. } \\
(1986)\end{array}$ \\
\hline
\end{tabular}


Table 9.11 (continued)

\begin{tabular}{|c|c|c|}
\hline Name of the disease & $\begin{array}{l}\text { Plant taxa and chemical class of the } \\
\text { compound }\end{array}$ & References \\
\hline $\begin{array}{l}\text { Rice blast disease } \\
\text { (Pyricularia oryzae) }\end{array}$ & $\begin{array}{l}\text { Jasmonic acid, hydroxybenzoic acid from } \\
\text { leaves of } \text { Oryza officinalis; pisiferic acid } \\
\text { from leaves of Chamaecyparis pisifera } \\
\text { (Cupressaceae); gingerenones A, B and C; } \\
\text { isogingerenone B from Zingiber officinale }\end{array}$ & $\begin{array}{l}\text { Kobayashi et al. } \\
\text { (1987), Endo et al. } \\
\text { (1990), Cho et al. } \\
\text { (1998) }\end{array}$ \\
\hline $\begin{array}{l}\text { Blue mold of tobacco } \\
\text { (Peronospora tabacina) }\end{array}$ & $\begin{array}{l}\text { Diterpenoids from Nicotiana tabacum of } \\
\text { Solanaceae }\end{array}$ & Reuveni et al. (1987) \\
\hline $\begin{array}{l}\text { Leaf and fruit pathogen } \\
\text { (Cladosporium } \\
\text { cladosporioides) }\end{array}$ & $\begin{array}{l}\text { Canaliculatol from bark of Stemonoporus } \\
\text { canaliculatus and long-chain alcohol from } \\
\text { Persea americana, phenylethanone from } \\
\text { Euodia lunuankenda, sinharine and } \\
\text { methylsinharine from Glycosmis } \\
\text { cyanocarpa, Illukumbin from Glycosmis } \\
\text { mauritiana (Rutaceae), phenylethanone } \\
\text { from Euodia lunuankenda (Lauraceae), } \\
\text { benzoquinone from Croton lacciferus } \\
\text { (Euphorbiaceae) }\end{array}$ & $\begin{array}{l}\text { Bokel et al. (1988), } \\
\text { Ratnayake Bandara } \\
\text { and Wimalasiri } \\
\text { (1988), Kumar et al. } \\
\text { (1990), Greger et al. } \\
\text { (1992), Pacher et al. } \\
\text { (2001), Springob and } \\
\text { Kutchan (2009), }\end{array}$ \\
\hline $\begin{array}{l}\text { Butt rot on conifers; } \\
\text { Douglas fir, spruce, fir, } \\
\text { hemlock, pine, and larch } \\
\text { (Phaeolus schweinitzii) }\end{array}$ & $\begin{array}{l}\text { Astringin and rhaponticin from Picea } \\
\text { sirchellsis (Pinaceae) }\end{array}$ & $\begin{array}{l}\text { Woodward and Pearce } \\
\text { (1988) }\end{array}$ \\
\hline $\begin{array}{l}\text { Sudden death of soybean } \\
\text { (SDS) pathogen, } \\
\text { damping off, corn rot, } \\
\text { root rot, wilting, and } \\
\text { necrotic spots (Fusarium } \\
\text { solani) }\end{array}$ & $\begin{array}{l}\text { Tomatine from Lycopersicum esculentum } \\
\text { (Solanaceae) }\end{array}$ & $\begin{array}{l}\text { Defago and Kern } \\
(1988)\end{array}$ \\
\hline $\begin{array}{l}\text { Gray mold of grapes } \\
\text { (Botrytis cinerea) }\end{array}$ & $\begin{array}{l}\text { Surangin B from Mammea longifolia } \\
\text { (Clusiaceae), cucurbitacin I of Ecballium } \\
\text { elaterium (Cucurbitaceae), chalcone from } \\
\text { Bauhinia manea (Leguminosae) }\end{array}$ & $\begin{array}{l}\text { Achenbach et al. } \\
\text { (1988), Har-Nun and } \\
\text { Meyer (1990), Deng } \\
\text { and Nicholson (2005) }\end{array}$ \\
\hline $\begin{array}{l}\text { Witches' broom of cocoa } \\
\text { tree (Crinipellis } \\
\text { perniciosa) }\end{array}$ & $\begin{array}{l}\text { Polymeric procyanidin from Theobroma } \\
\text { cacao of Sterculiaceae }\end{array}$ & $\begin{array}{l}\text { Brownlee et al. } \\
\text { (1990), Duke (2004) }\end{array}$ \\
\hline $\begin{array}{l}\text { Fusarium wilt of } \\
\text { pathogen (Fusarium } \\
\text { oxysporum f. sp. } \\
\text { lycopersici) }\end{array}$ & $\begin{array}{l}\text { Jodrellin B and oerodin from Scutellaria } \\
\text { woronowii and S. violacea of Lamiaceae }\end{array}$ & Cole et al. (1991) \\
\hline $\begin{array}{l}\text { Collar rot, root rot, } \\
\text { damping off, wire stem, } \\
\text { primarily the pathogen of } \\
\text { herbs (Rhizoctonia } \\
\text { solani) }\end{array}$ & $\begin{array}{l}\text { Dihydrochalcone from twigs and leaves of } \\
\text { Psidium acutangulum (Myrtaceae), } \\
\text { coumarin from Mammea longifolia } \\
\text { (Clusiaceae), dolichin of Dolichos lablab } \\
\text { (Fabaceae), methylquercetin from leaf of } \\
\text { Wedelia biflora }\end{array}$ & $\begin{array}{l}\text { Miles et al. (1991), } \\
\text { Miles et al. (1993), } \\
\text { Lee et al. (2003), } \\
\text { Deng and Nicholson } \\
\text { (2005) and } \\
\text { Yoganandam et al. } \\
(2009)\end{array}$ \\
\hline
\end{tabular}


Table 9.11 (continued)

\begin{tabular}{|c|c|c|}
\hline Name of the disease & $\begin{array}{l}\text { Plant taxa and chemical class of the } \\
\text { compound }\end{array}$ & References \\
\hline $\begin{array}{l}\text { Spoilage of fruit and } \\
\text { vegetables } \\
\text { (Cladosporium } \\
\text { sphaerospermum) }\end{array}$ & $\begin{array}{l}\text { Nonglycosidic iridoid from Alibertia } \\
\text { macrophylla (Rubiaceae) }\end{array}$ & Young et al. (1992) \\
\hline $\begin{array}{l}\text { Late blight of potato or } \\
\text { tomato (Phytophthora } \\
\text { infestans), bbrown rust } \\
\text { (Puccinia recondita), } \\
\text { rice blast disease } \\
\text { (Pyricularia grisea) }\end{array}$ & Emodin from Cassia tora (Leguminosae) & Kim et al. (2004) \\
\hline $\begin{array}{l}\text { Pathogen of } \\
\text { Rhododendron } \\
\text { (Pestalotia guepinii), } \\
\text { cortical stem rot } \\
\text { (Fusarium avenaceum), } \\
\text { Drechslera leaf spot } \\
\text { (Drechslera spp.) }\end{array}$ & $\begin{array}{l}\text { Trifolin and hyperoside from } \\
\text { Camptotheca acuminata (Cornaceae) }\end{array}$ & Li et al. $(2005 a, b)$ \\
\hline $\begin{array}{l}\text { Strawberry pathogen } \\
\text { (Cladosporium } \\
\text { fragariae) and } \\
\text { anthracnose of Lupin sp., } \\
\text { Cladosporium acutatum }\end{array}$ & $\begin{array}{l}\text { Alkaloid (findersine, anhydroevoxine, } \\
\text { haplamine) from Haplophyllum sieversii } \\
\text { (Rutaceae) }\end{array}$ & Cantrell et al. (2005) \\
\hline $\begin{array}{l}\text { Pre- and postharvest } \\
\text { fungal disease of cereal } \\
\text { grains, legumes, and tree } \\
\text { nuts (Aspergillus flavus) }\end{array}$ & Alkaloids from Datura metel & Dabur et al. (2005) \\
\hline $\begin{array}{l}\text { Early blight of potato } \\
\text { and rice (Alternaria } \\
\text { solani) }\end{array}$ & $\begin{array}{l}\text { Meliacin-type of nortriterpenoid from } \\
\text { Chisocheton paniculatus (Meliaceae) }\end{array}$ & Yang et al. (2009) \\
\hline $\begin{array}{l}\text { Take-all fungus in wheat, } \\
\text { barley, rye, oat, turf grass } \\
\text { (Gaeumannomyces } \\
\text { graminis) }\end{array}$ & Avenacins from Avena sativa (Poaceae) & $\begin{array}{l}\text { De Bertoldi et al. } \\
\text { (2009) }\end{array}$ \\
\hline
\end{tabular}

Sclerotinia sp. Phenolic structures when contain a carbonyl group are known to be flavones, and the addition of an extra 3-hydroxyl group indicates flavonol. Flavonoids are also known to hydroxylated phenolics but occurring as a C6-C3 unit linked to aromatic ring. Not only plant samples directly but also plant derivatives like porpolis (galangin isolated from the bee glue or resinous mixture produced as a result of the mixture of tree buds, sap, botanical extracts, and bee exudates) are shown to be antifungal against green rot or mold of tangerine (pathogens Penicillium digitatum, $P$. italicum) and also control postharvest disease of cereal grains, legumes, and tree nuts caused by A. flavus (Afolayan and Meyer 1997). Flavones (6,7,4'-trihydroxy-3,5'dimethoxyflavone, 5,5'-dihydroxy-8,2',4'-trimethoxyflavone) from Artemisia giraldi are effective against A. flavus infections (Cowan 1999). Leaf wax of Arrabidaea brachypoda (Brazilian medicinal plant from Bignoniaceae) contains 
Table 9.12 Direct extracts of plants tested for antifungal potency

\begin{tabular}{|c|c|c|}
\hline Plant species & Fungal pathogen & References \\
\hline Reynoutria sachalinensis & $\begin{array}{l}\text { Uncinula necator (the causal } \\
\text { pathogen of grapevine } \\
\text { (powdery mildew) }\end{array}$ & $\begin{array}{l}\text { Herger et al. (1988) } \\
\text { and Abdu-Allah } \\
\text { and Elyousr (2017) }\end{array}$ \\
\hline $\begin{array}{l}\text { Cassia tora (dealcoholized extract of } \\
\text { leaves) }\end{array}$ & Aspergillus niger & $\begin{array}{l}\text { Mukherjee et al. } \\
(1996)\end{array}$ \\
\hline $\begin{array}{l}\text { Thymol, carvacrol, citronellol, } \\
\text { geraniol, citral, perillyl, menthol, } \\
\text { eugenol, 1,8-cineole, Y-terpinene, } \\
\text { p-cymene, anethole from several plants } \\
\text { like Thymus vulgaris, T. spicata, } T \text {. } \\
\text { pulegioides, Cymbopogon citratus, } \\
\text { Cymbopogon martini }\end{array}$ & $\begin{array}{l}\text { Fusarium moniliforme, } \\
\text { Rhizoctonia solani, } \\
\text { Phytophthora capsici, } \\
\text { Monilinia fructicola, Botrytis } \\
\text { cinerea, Curvularia lunata }\end{array}$ & $\begin{array}{l}\text { Mueller-Riebau } \\
\text { et al. (1995), } \\
\text { Krishna Kishore } \\
\text { et al. (2007) }\end{array}$ \\
\hline Phlomis fruticosa (Jerusalem sage) & $\begin{array}{l}\text { Aspergillus niger, Penicillium } \\
\text { ochrochloron, Trichoderma } \\
\text { viride, Fusarium tricinctum, } \\
\text { Phomopsis helianthi, } \\
\text { Cladosporium } \\
\text { cladosporioides, Aspergillus } \\
\text { ochraceus }\end{array}$ & Ristic et al. (2000) \\
\hline Vernonia tenoreana & Aspergillus niger, A. flavus & $\begin{array}{l}\text { Ogundare et al. } \\
\text { (2006) }\end{array}$ \\
\hline Tagetes erecta & $\begin{array}{l}\text { Fusarium wilt (Fusarium } \\
\text { oxysporum f. sp. niveum) }\end{array}$ & Du et al. (2017) \\
\hline $\begin{array}{l}\text { Garlic (Allium sativum L.), neem } \\
\text { (Azadirachta indica L.) }\end{array}$ & $\begin{array}{l}\text { Narrow brown leaf spot } \\
\text { (Cercospora oryzae), sheath } \\
\text { blight (Rhizoctonia solani), } \\
\text { sheath rot (Sarocladium } \\
\text { oryzae), false smut } \\
\text { (Ustilaginoidea virens) }\end{array}$ & $\begin{array}{l}\text { Mahmud et al. } \\
\text { (2018) }\end{array}$ \\
\hline Neem seed and eucalyptus extract & $\begin{array}{l}\text { Fusarium oxysporum f. sp. } \\
\text { lycopersici (FOL) tomato crop } \\
\text { causing wilt disease }\end{array}$ & $\begin{array}{l}\text { Poussio et al. } \\
(2018)\end{array}$ \\
\hline Stilbene and resveratrol & Plasmopara viticola & $\begin{array}{l}\text { Krzyzaniak et al. } \\
(2018)\end{array}$ \\
\hline $\begin{array}{l}\text { Zingiber officinale, Piper nigrum, } \\
\text { Azadirachta indica, Nicotiana } \\
\text { tabacum, Carica papaya }\end{array}$ & $\begin{array}{l}\text { P. expansum pathogenic of } \\
\text { yam tubers (Dioscorea } \\
\text { rotundata) }\end{array}$ & Gwa et al. (2018) \\
\hline $\begin{array}{l}\text { Neem (Azadirachta indica), lantana } \\
\text { (Lantana camara), and eucalyptus } \\
\text { (Eucalyptus globulus) }\end{array}$ & Pyricularia oryzae & $\begin{array}{l}\text { Wasimfiroz et al. } \\
(2018)\end{array}$ \\
\hline $\begin{array}{l}\text { Onion (Allium cepa), garlic (Allium } \\
\text { sativum), lantana (Lantana camara), } \\
\text { marigold (Tagetes erecta), dathura } \\
\text { (Datura stramonium), tulasi Ocimum } \\
\text { sanctum), eupatorium (Eupatorium } \\
\text { rugosum), parthenium (Parthenium } \\
\text { hysterophorus), neem (Azadirachta } \\
\text { indica) }\end{array}$ & $\begin{array}{l}\text { Botrytis oryzae (brown leaf } \\
\text { spot of paddy) }\end{array}$ & $\begin{array}{l}\text { Channakeshava and } \\
\text { Pankaja (2018) }\end{array}$ \\
\hline
\end{tabular}


Table 9.12 (continued)

\begin{tabular}{l|l|l}
\hline Plant species & Fungal pathogen & References \\
\hline $\begin{array}{l}\text { Methanol extracts of Eucalyptus } \\
\text { tereticornis, Ammi visnaga, } \\
\begin{array}{l}\text { Azadirachta indica, Rheum Palmatum, } \\
\text { Adansonia digitata }\end{array}\end{array}$ & $\begin{array}{l}\text { Rhizoctonia solani (root rot of } \\
\text { maize) }\end{array}$ & $\begin{array}{l}\text { Rashad et al. } \\
(2018)\end{array}$ \\
\hline $\begin{array}{l}\text { Lawsonia inermis (henna), Acalypha } \\
\text { wilkesiana (acalypha), Melia } \\
\text { azedarach (chinaberry), Punica } \\
\text { granatum (pomegranate), Lantana } \\
\text { camara (lantana) }\end{array}$ & $\begin{array}{l}\text { Puccinia triticina (leaf rust } \\
\text { fungus) }\end{array}$ & Draz et al. (2019) \\
\hline Azadirachta indica & $\begin{array}{l}\text { Sclerospora graminicola } \\
\text { (pearl millet downy } \\
\text { Mildew) }\end{array}$ & Atri et al. (2019) \\
\hline
\end{tabular}

cirsiliol, cirsimaritin, and hispidulin and is showed to be effective against Cladosporium sphaerospermum (Alcerito et al. 2002). Galeotti et al. (2008) studied the antifungal activity of kaempferol 3-O- $\beta$-d-glucopyranosyl(1-2)-O- $\beta$-dglucopyranosyl(1-2)-O-[ $\alpha$-1-rhamnopyranosyl-(1-6)]- $\beta$-d-glucopyranoside isolated from Dianthus caryophyllus (carnation, a member of Caryophyllaceae family) against Fusarium oxysporum f. sp. dianthi (Galeotti et al. 2008). Fusarium culmorum, a serous pathogen of seedling blight, foot rot, ear blight, stalk rot, and common rot of cereals and grasses, is found to be inhibited by six commercial coumarins: bergapten, herniarin, umbelliferone, xanthotoxin, and scopoletin. Tithonia diversifolia, the source of tithoniamarin, is effective against the anther smut fungus Microbotryum violaceum, earlier known as Ustilago violacea (Yemele-Bouberte et al. 2006). Berberine and jatrorrhizine (alkaloids) are isolated from Mahonia aquifolium (a plant of Berberidaceae family commonly called as Oregon grape and native to western North America) and are effective against human pathogenic Candida species. Pathogens of mango (C. gloeosporioides), anthracnose of lupin species, postbloom fruit drop of citrus, Valencia and navel oranges in Florida (caused by $C$. acutatum), and strawberry (caused by Colletotrichum fragariae) are inhibited by findersine, anhydroevoxine, and haplamine (Cantrell et al. 2005). Roots of Cyathobasis fruticulosa are source of beta-carboline, tryptamine, and phenylethylamine-derived alkaloids and are antifungal in nature (Bahceevli et al. 2005).

\subsubsection{Essential Oil}

Essential oils (EOs) of aromatic and medicinal plant origin are reported to possess antifungal properties and are of wide spectrum in their application for the control of agricultural pathogen (Table 9.13). EOs are mainly categorized under the plants' secondary metabolites and may fall under the category of terpenes, ketones, esters, aromatic phenols, ethers, alcohols, oxides, etc. (Fig. 9.7). They act by inhibiting the fungal hyphal growth either by accumulating in the fungal cell membrane or by 
Table 9.13 Common sources of popular essential oils with antifungal property

\begin{tabular}{|c|c|c|}
\hline Sl. no. & Name of the plant & Family \\
\hline 1 & Anethum graveolens & Apiaceae \\
\hline 2 & Aniba rosaeodora & Lauraceae \\
\hline 3 & Artemisia absinthium & Asteraceae \\
\hline 4 & Boswellia thurifera & Buseraceae \\
\hline 5 & Brassica nigra & Brassicaceae \\
\hline 6 & Bunium persicum & Apiaceae \\
\hline 7 & Cestrum nocturnum & Solanaceae \\
\hline 8 & Calocedrus macrolepis var. formosana & Cupressaceae \\
\hline 9 & Cananga odorata & Annonaceae \\
\hline 10 & Carum carvi & Apiaceae \\
\hline 11 & Cedrus deodara & Pinaceae \\
\hline 12 & Chenopodium ambrosioides & Amaranthaceae \\
\hline 13 & Cinnamomum jensenianum & Lauraceae \\
\hline 14 & Cinnaтотит zeylanicum & Lauraceae \\
\hline 15 & Cicuta virosa & Apiaceae \\
\hline 16 & Citrus limon & Rutaceae \\
\hline 17 & Cuminum cyminum & Apiaceae \\
\hline 18 & Cymbopogon citratus & Poaceae \\
\hline 19 & Cymbopogon martini & Poaceae \\
\hline 20 & Cymbopogon winterianus & Poaceae \\
\hline 21 & Daucus carota & Apiaceae \\
\hline 22 & Echinophora spinosa & Apiaceae \\
\hline 23 & Eucalyptus citriodora & Myrtaceae \\
\hline 24 & Eugenia caryophyllata & Myrtaceae \\
\hline 25 & Foeniculum sativum & Apiaceae \\
\hline 26 & Foeniculum vulgare & Apiaceae \\
\hline 27 & Helichrysum arenarium & Asteraceae \\
\hline 28 & Hypericum perforatum & Hypericaceae \\
\hline 29 & Illicium verum & Liliaceae \\
\hline 30 & Juniperus excelsa & Cupressaceae \\
\hline 31 & Laurus nobilis & Lauraceae \\
\hline 32 & Lavandula intermedia & Lamiaceae \\
\hline 33 & Lavandula officinalis & Lamiaceae \\
\hline 34 & Lippia rugosa & Verbenaceae \\
\hline 35 & M. albanica & Lamiaceae \\
\hline 36 & M. thymifolia & Lamiaceae \\
\hline 37 & Majorana hortensis & Lamiaceae \\
\hline 38 & Matricaria chamomilla & Asteraceae \\
\hline 39 & Mentha arvensis & Lamiaceae \\
\hline 40 & Mentha piperita & Lamiaceae \\
\hline 41 & Mentha spicata & Lamiaceae \\
\hline 42 & Micromeria dalmatica & Lamiaceae \\
\hline 43 & Monarda spp. & Lamiaceae \\
\hline 44 & Myrrhis odorata & Apiaceae \\
\hline
\end{tabular}


Table 9.13 (continued)

\begin{tabular}{|c|c|c|}
\hline Sl. no. & Name of the plant & Family \\
\hline 45 & Nepeta rtanjensis & Lamiaceae \\
\hline 46 & Ocimum basilicum & Lamiaceae \\
\hline 47 & Ocimum majorana & Lamiaceae \\
\hline 48 & Ocimum sanctum & Lamiaceae \\
\hline 49 & Origanum vulgare & Lamiaceae \\
\hline 50 & Origanum onites & Lamiaceae \\
\hline 51 & Portenschlagiella ramosissima & Apiaceae \\
\hline 52 & Rosmarinus officinalis & Lamiaceae \\
\hline 53 & Seseli aппиит & Apiaceae \\
\hline 54 & Seseli globiferum & Apiaceae \\
\hline 55 & Seseli montanum subsp. tommasinii & Apiaceae \\
\hline 56 & Seseli rigidum & Apiaceae \\
\hline 57 & Seseli scardica & Apiaceae \\
\hline 58 & Salvia brachyodon & Lamiaceae \\
\hline 59 & Salvia fruticose & Lamiaceae \\
\hline 60 & Salvia officinalis & Lamiaceae \\
\hline 61 & Salvia pomifera subsp. Calycina & Lamiaceae \\
\hline 62 & Salvia sclarea & Lamiaceae \\
\hline 63 & Sardinian desoleana & Lamiaceae \\
\hline 64 & Sassafras albidum & Lauraceae \\
\hline 65 & Satureja hortensis & Lamiaceae \\
\hline 66 & Satureja montana & Lamiaceae \\
\hline 67 & Satureja thymbra & Lamiaceae \\
\hline 68 & Seseli montanum subsp. tommasinii & Apiaceae \\
\hline 69 & Syzygium aromaticum & Myrtaceae \\
\hline 70 & Tagetes patula & Asteraceae \\
\hline 71 & Thymbra spicata & Lamiaceae \\
\hline 72 & Thymus pulegioides & Lamiaceae \\
\hline 73 & Thymus vulgaris & Lamiaceae \\
\hline 74 & Trachyspermum ammi & Apiaceae \\
\hline 75 & Zataria multiflora & Lamiaceae \\
\hline
\end{tabular}

crossing the cell membrane and entering into the eukaryotic cell. Being lipophilic in their chemical nature, they can easily cross the cell and interrupt in sterol biosynthesis leading to growth retardation and finally cell death. As sterols are the maintenance, compounds of cellular integrity treatment with EO cause fungal cell death. Metabolic processes like respiration, replication, transcription, and translation are inhibited. Membrane permeability is drastically changed as they cause swelling and disruption of protein-lipid-protein membrane. Leakage of useful ions like $\mathrm{Ca}^{2+}$ and $\mathrm{K}^{+}$causes cell death. Thymol, carvacrol, eugenol, and related phenolic compounds cause $\mathrm{H}^{+}$and $\mathrm{K}^{+}$leakage and water imbalance and deplete intracellular high-energy molecule (ATP). Essential oils are extracted from almost every parts of a plant, for example, roots, fruits, barks, twigs, leaves, seeds, and flowers, by several extraction procedures that include hydro and steam distillation, cold pressing, and 
<smiles>Cc1ccc(C(C)C)c(O)c1</smiles>

Thymol<smiles>CC(C)=CCC/C(C)=C/CO</smiles>

Geraniol<smiles>C=C1CCC2CC1C2(C)C</smiles>

$\beta$-pinene<smiles>C=C(C)C1CC=C(C)CC1</smiles><smiles>Cc1ccc(C(C)C)cc1O</smiles>

Carvacrol<smiles>C=CCc1ccc(O)c(OC)c1</smiles>

Eugenol<smiles>CC1=CCC2CC1C2(C)C</smiles>

$\alpha$-pinene<smiles>O=C/C=C/c1ccccc1</smiles><smiles>CC(C)=CCC[C@H](C)CCO</smiles>

Citronellol

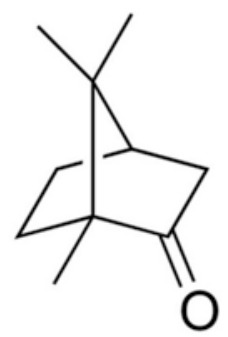

Camphor

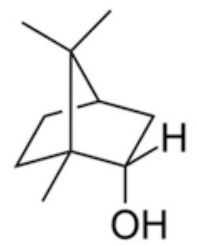

Borneol<smiles>C=CC(C)(O)CCC=C(C)C</smiles>

Fig. 9.7 Common ingredients of essential oils of antifungal importance

fermentation. The antifungal efficacy is checked by direct contact of the essential oil components and fungal hypha and poison food method, following micro or broth dilution techniques, or in vivo fumigation assay is also performed in case of field trials. 
Essential oils from leaves of Chenopodium ambrosioides, a member of Amaranthaceae family, are effective against storage fungi Aspergillus flavus, A. glaucus, A. niger, A. oryzae, Colletotrichum gloeosporioides, C. musae, Fusarium oxysporum, and Fusarium semitectum (Jardim et al. 2008). Lemongrass oil from Cymbopogon citratus and Cymbopogon martini are potent inhibitors of Botrytis cinerea, Rhizoctonia solani, Aspergillus tamari, A. fumigatus, and A. conicus (Tzortzakis and Economakis 2007; Mishra et al. 2015). The members of Lamiaceae family are well known for their pungent odor and are tested for their antifungal activity by agar and broth dilution methods (Roby et al. 2013; Omidbeygi et al. 2007). Essential oils extracted from Laurus nobilis, Syzygium aromaticum, and Origanum vulgare are effective antifungal compounds against two pathogens of rice, Fusarium culmorum and Fusarium verticillioides (Rosello et al. 2015). Essential oils from Cymbopogon exhibited antifungal activities against rot molds (Soundharrajan et al. 2003). Antifungal activities of peppermint and sweet basil were tested against plant pathogenic fungi S. sclerotiorum, Rhizopus stolonifer, and Mucor sp. (Edris and Farrag 2003). Antifungal activity of $\beta$-dolabrin, $\gamma$-thujaplicin, and 4-acetyltropolone was tested against Pythium aphanidermatum IFO 32440 (Morita et al. 2004). Boyraz and Ozcan (2006) tested the antifungal activity of the essential oils isolated from wild Turkish summer savory (Satureja hortensis). Essential oils (carvacrol, thymol, p-cymene) extracted from Origanum acutidens are effective against phytopathogens. Growth of A. humicola, Colletotrichum gloeosporioides, Rhizoctonia solani, and Phytophthora cactorum was inhibited by the essential oil of Asarum heterotropoides var. mandshuricum (Dan et al. 2010). Though there are several reports of essential oils being potent anti-phytopathogenic (Penicillium purpurogenum, Rhizopus stolonifer, Spondylocladium austral, Penicillium digitatum, Penicillium luteum, Monilinia laxa, Curvularia lunata, etc.) in nature, still there are some problems regarding their maximum use and optimum effectivity. That includes their volatile natures, requirement of close systems, and degradation of EOs by oxidation due to presence of extreme amount of hydrogenated compounds (Kim et al. 2003).

\subsection{Conclusion and Future Prospects}

We are nourished by Mother Nature. So it is our prime duty to keep up the normal equilibrium of natural parameters. But in a way to seek solutions, some steps taken toward success may have negative impact on our environment. To fight against the fungal pathogens for the ensuring of better crop productivity, use of chemical fungicide is just another example of that fact. But we must emphasize on products from direct natural origin over the chemically synthesized one. Natural products are the best weapon to fight fungal pathogenic diseases on economically important crop species. They are less toxic, stable, and of no side effects when used in crop fields. The crying need of modern era is obtaining pathogen-free crop species in one hand and assurance of environmental sustainability on the other. Fungal and bacterial products are already used in large scales followed by the plants' secondary 
metabolites. Phytoalexins as internal molecules are the plants' own defense system. The detailed biochemical analysis of the phytoalexins and study of their regulatory mechanisms are opening up new horizons for universal use of phytoalexin inducing elicitors as plant defense enhancers. Mycorrhizae provide the basic line of physical barrier against pathogenic invasion, and reports include their ability to enhance plant growth, thus making the plant nonsusceptible to fungal attack. Endophyte on the other hand can enhance the plants' defense system by direct incorporation and open up popular angles of green immunization or plant vaccination. Researches on these fields are still scanty, but in the near future, they could lead to the ultimate solution of fungal pathogenic crop loss.

\section{References}

Abdu-Allah GAM, Abo-Elyousr KAM (2017) Effect of certain plant extracts and fungicides against powdery mildew disease of Grapevines in Upper Egypt. Arch Phytopathol Plant Protect:1-13

Abu-Ghannam N, Rajauria G (2013) Antimicrobial activity of compounds isolated from algae. In: Functional ingredients from algae for foods and Nutraceuticals. Woodhead, New Delhi, pp 287-306

Achenbach H, Stocker M, Constenla MA (1988) Flavonoid and other constituents of Bauhinia manca. Phytochemistry 27:1835-1841

Adrian M, Jeandet P (2012) Effects of resveratrol on the ultrastructure of Botrytis cinerea conidia and biological significance in plant/pathogen interactions. Fitoterapia 83:1345-1350

Adrian M, Jeandet P, Veneau J, Weston LA, Bessis R (1997) Biological activity of resveratrol, a stilbenic compound from grapevines, against Botrytis cinerea, the causal agent for gray mold. J Chem Ecol 23:1689-1702

Afolayan AJ, Meyer JJ (1997) The antimicrobial activity of 3, 5, 7-trihydroxyflavone isolated from the shoots of Helichrysum aureonitens. J Ethnopharmacol 57:177-181

Ahsan T, Chen J, Zhao X, Irfan M, Wu Y (2017) Extraction and identification of bioactive compounds (eicosane and dibutyl phthalate) produced by Streptomyces strain KX852460 for the biological control of Rhizoctonia solani AG-3 strain KX852461 to control target spot disease in tobacco leaf 2-9. AMB Express 7:54

Ahuja I, Kissen R, Bones AM (2012) Phytoalexins in defense against pathogens. Trends Plant Sci 17:73-90

Ajith PS, Lakshmidevi N (2010) Effect of volatile and non-volatile compounds from Trichoderma spp. against Colletotrichum capsici incitant of anthracnose on bell peppers. Nat Sci 8:265-269

Alam A, Tripathi A, Vats S, Behra KK, Sharma V (2011) In vitro antifungal efficacies of aqueous extract of Dumortiera hirsuta (Swaegr.) Nees against sporulation and growth of postharvest phytopathogenic fungi. Arch Bryol 103:1-9

Al-Askar AA, Baka ZA, Rashad YM, Ghoneem KM, Abdulkhair WM, Hafez EE, Shabana YM (2015) Evaluation of Streptomyces griseorubens E44G for the biocontrol of Fusarium oxysporum f. sp. lycopersici: ultrastructural and cytochemical investigations. Ann Microbiol 65(4):1815-1824

Alban R, Guerrero R, Toro M (2013) Interactions between a root-knot nematode (Meloidogyne exigua) and arbuscular mycorrhizae in coffee plant development (Coffea arabica). Am J Plant Sci 4:19-23

Alcerito T, Barbo FE, Negri G, Santos DYAC, Meda CI, Young MCM, Chávez D, Blatt CTT (2002) Foliar epicuticular wax of Arrabidaea brachypoda: flavonoids and antifungal activity. Biochem Syst Ecol 30:677-683

Aldridge DC, Turner WBJ (1970) Metabolites of Helminthosporium monoceras: structures of monocerin and related benzopyrans. Chem Soc Sect C 18:2598-2600 
Allen EH, Thomas CA (1971) Trans-trans-3, 11-tridecadiene5, 7, 9-triyne-1,2-diol, an antifungal polyacetylene from diseased safflower (Carthamus tinctorius). Phytochemistry 10:15791582

Alpha CJ, Campos M, Jacobs-Wagner C, Strobel SA (2015) Mycofumigation by the volatile organic compound-producing fungus Muscodor albus induces bacterial cell death through DNA damage. Appl Environ Microbiol 81:1147-1156

Amer MA, Abou-El-Seud (2008) Mycorrhizal fungi and Trichoderma harzianum as biocontrol agents for suppression of Rhizoctonia solani damping off disease of tomato. Commun Agric Appl Biol Sci 73(2):217-232

Amin F, Razdan VK, Mohiddin FA, Bhat KA, Sheikh PA (2010) Effect of volatile metabolites of Trichoderma species against seven fungal plant pathogens in vitro. J Phytol 2:34-37

Anitha R, Murugesan K (2005) Production of gliotoxin on natural substrates by Trichoderma virens. J Basic Microbiol 45(1):12-19

Aramsirirujiwet Y, Gumlangmak C, Kitpreechavanich V (2016) Studies on antagonistic effect against plant pathogenic fungi from endophytic fungi isolated from Houttuynia cordata Thunb. and screening for siderophore and indole-3-acetic acid production. KKU Res J 21(1):55-66

Arruda RS, Mesquini RM, Schwan-Estrada KRF, Nascimento JF (2012) Effect of mushroom extracts in the induction of phytoalexins and in the control of soy oidium in a greenhouse. Biosci J 28:164-172

Atkinson S, Berta G, Hooker JE (1994) Impact of mycorrhizal colonisation on root architecture, root longevity and the formation of growth regulators. In: Gianinazzi S, Schuepp H (eds) Impact of Arbuscular Mycorrhizas on sustainable agriculture and natural ecosystems. ALS, Birkhauser Verlag, Basel, pp 47-60

Atmosukarto I, Castillo U, Hess WM, Sears J, Strobel G (2005) Isolation and characterization of Muscodor albus I-41.3s, a volatile antibiotic producing fungus. Plant Sci 169:854-861

Atri A, Singh N, Oberoi H (2019) Influence of seed priming on the development of pearl millet downy mildew (Sclerospora graminicola). Indian Phytopathol 72:1-7

Axford LC, Simpson TJ, Willis CL (2004) Synthesis and incorporation of the first Polyketide synthase free intermediate in Monocerin biosynthesis. Angew Chem Int Ed 43:727-730

Azcon-Aguilar C, Barea JM (1996) Mycorrhiza 6:457464

Aziz A, Poinssot B, Daire X, Adrian M, Bezier A, Lambert B, Joubert JM, Pugin A (2003) Laminarin elicits defense responses in grapevine and induces protection against Botrytis cinerea and Plasmopara viticola. Mol Plant-Microbe Interact 16:1118-1128

Azura NAB, Yusoff M, Tan GYA, Jegadeesh R, Appleton DR, Vikineswary S (2016) Streptomyces sanglieri which colonised and enhanced the growth of Elaeis guineensis Jacq. Seedlings was antagonistic to Ganoderma boninense in in vitro studies. J Ind Microbiol Biotechnol 43(4):485-493

Bagyaraj DJ (2006) Current status of biological control of plant diseases using antagonistic organisms in India. PDBC Pub Bangalore, Bangalore, pp 125-134

Bagyaraj DJ, Chawla G (2012) Status and prospects for enhancing the uptake of antagonistic organisms for nematode Management in India. NBAII Pub Bangalore, Bangalore, pp 74-89

Bahceevli AK, Kurucu S, Kolak U, Topçu G, Adou E (2005) Alkaloids and aromatics of Cyathobasis fruticulosa (Bunge) Aellen. J Nat Prod 68:956-958

Banerjee RD (2000) Antimicrobial activities of bryophytes a review. Perspect Indian Bryol:55-74

Banerjee RD, Sen SP (1979) Antibiotic activity of bryophytes. Bryologist 82:141-153

Banerjee D, Strobel GA, Booth E, Geary B, Sears J, Spakowicz D, Busse S (2010a) An endophytic Myrothecium inundatum producing volatile organic compounds. Mycosphere 1(3):229-240

Banerjee D, Strobel GA, Geary B, Sears J, Ezra D, Liarzi O, Coombs J (2010b) Muscodor albus strain GBA, an endophytic fungus of Ginkgo biloba from United States of America, produces volatile antimicrobials. Mycology 1(3):179-186

Baum C, El-Tohamy W, Gruda N (2015) Increasing the productivity and product quality of vegetable crops using arbuscular mycorrhizal fungi: a review. Sci Hortic (Amsterdam) 187:131-141

Ben Salah I, Aghrouss S, Douira A, Aissam S, El Alaoui-Talibi Z, Filali-Maltouf A, El Modafar C (2018) Seaweed polysaccharides as bio-elicitors of natural defenses in olive trees against Verticillium wilt of olive. J Plant Interact 13:248-255 
Berdy J (2012) Thoughts and facts about antibiotics: where we are now and where we are heading. J Antibiot 65:385-395

Bodade RG, Borkar PS, Arfeen MS, Khobragade CN (2008) In vitro screening of bryophytes for antimicrobial activity. J Med Plan Theory 7:23-28

Bodker L, Kjoller R, Rosendahl S (1998) Effect of phosphate and the arbuscular mycorrhizal fungus Glomus intraradices on disease severity of root rot of peas (Pisum sativum) caused by Aphanomyces euteiches. Mycorrhiza 8:169-174

Bokel N, Diyasenu MNC, Gunatilaka AAL, Kraus W, Sotheeswaran S (1988) Canaliculatol, an antifungal resveratrol trimer from Stemonoporous canaliculatus. Phytochemistry 27:377-380

Bonde MR, Millar RL, Ingham JL (1973) Induction and identification of sativan and vestitol as two phytoalexins from Lotus corniculatus. Phytochemistry 12(12):2957-2959

Brady SF, Wagenaar MM, SinghMP JJE, Clardy J (2000) The cytosporones, new octaketide antibiotics isolated from an endophytic fungus. Org Lett 2:4043-4046

Braga MR (1991) Phytoalexins induction in Rubiaceae. J Chem Ecol 17:1079-1090

Browne LM, Conn KL, Ayer WA, Tewari JP (1991) The camalexins: new phytoalexins produced in the leaves of Camelina sativa (Cruciferae). Tetrahedron 47:3909-3914

Brownlee HE, McEuen AR, Hedger J, Scott IM (1990) Anti-fungal effects of cocoa tannin on the witches' broom pathogen Crinipellis pernicious. Physiol Mol Plant Pathol 36:39-48

Budi SW, Tuinen DV, Martinotti G, Gianinazzi S (1999) Applied and environmental microbiology. Am Soc Microbiol 65(11):5148-5150

Bungtongdee N, Sopalun K, Laosripaiboon W, Iamtham S (2019) The chemical composition, antifungal, antioxidant and antimutagenicity properties of bioactive compounds from fungal endophytes associated with Thai orchids. J Phytopathol 167:56-64

Cantrell CL, Schrader KK, Mamonov LK, Sitpaeva GT, Kustova TS, Dunbar C (2005) Isolation and identification of antifungal and antialgal alkaloids from Haplophyllum sieversii. J Agric Food Chem 53:7741-7748

Cao L, Qiu Z, You J, Tan H, Zhou S (2005) Isolation and characterization of endophytic Streptomyces antagonists of Fusarium wilt pathogen from surface sterilized banana roots. FEMS Microbiol Lett 247:147-152

Cartwright P (1981) Isolation and characterization of two phytoalexins from rice as momilactones A and B. Phytochemistry 20:535-537

Castillo U, Strobel G, Ford E, Hess W, Porter H, Jensen J et al (2002) Munumbicins, wide- spectrum antibiotics produced by Streptomyces NRRL 30562, endophytic on Kennedia nigriscans. Microbiology 148:2675-2685

Castillo UF, Strobel GA, Mullenberg K, Condron MM, Teplow DB, Folgiano V et al (2006) Munumbicins E-4 and E-5: novel broad-spectrum antibiotics from Streptomyces NRRL 3052. FEMS Microbiol Lett 255:296-300

Cavalcanti LS (2005) Aspectos bioquímicos e moleculares da resistência induzida. In: . et al. (Eds.). Indução de resistência em plantas a patógenos e insetos. Piracicaba: FEALQ, 81:124

Cavin AL, Hay AE, Marston A, Stoeckli H, Scopelliti R, Diallo D, Hostettmann K (2006a) Bioactive diterpenes from the fruits of Detarium microcarpum. J Nat Prod 69:768-773

Channakeshava C, Pankaja NS (2018) In vitro evaluation of fungicides, plant extracts and biocontrol agents against brown leaf spot of paddy. Int J Curr Microbiol App Sci 7(5):127-132

Cavin AL, Hay AE, Marston A, Stoeckli H, Scopelliti R, Diallo D, Hostettmann K (2006b) Bioactive diterpenes from the fruits of Detarium microcarpum. J Nat Prod 69:768-773

Chaube HS, Pundhir VS (2005) Crop diseases and their management. PHI Learning Private Limited, Delhi

Chen T, Lu J, Kang B, Lin M, Ding L, Zhang L, Chen G, Chen S, Lin H (2018) Antifungal activity and action mechanism of ginger oleoresin against Pestalotiopsis microspora isolated from Chinese olive fruits. Front Microbiol 9:2583

Chen X, Sang X, Li S, Zhang S, Bai L (2010) Studies on a chlorogenic acid-producing endophytic fungi isolated from Eucommia ulmoides Oliver. J Ind Microbiol Biotechnol 37:447-454

Cheng SS, Liu JY, Chang EH, Chang ST (2008) Antifungal activity of cinnamaldehyde and eugenol congeners against wood-rot fungi. Bioresour Technol 99:5145-5149 
Cheung RCF, Wong JH, Pan WL, Chan YS, Yin CM, Dan XL, Wang HX, Fang EF, Lam SK, Ngai PHK (2014) Antifungal and antiviral products of marine organisms. Appl Microbiol Biotechnol 98:3475-3494

Chludil HD, Muniain CC, Seldes AM, Maier MS (2002) Cytotoxic and antifungal triterpene glycosides from the Patagonian Sea cucumber Hemoiedema spectabilis. J Nat Prod 65:860-865

Cho JY, Moon JH, Seon KY, Park KH (1998) Antimicrobial activity of 4-Hydroxybenzoic acid and trans 4-hydroxycinnamic acid isolated and identified from rice hull. Biosci Biotechnol Biochem 62:2273-2276

Chowdhary K, Kaushik N (2018) Diversity and antifungal activity of fungal endophytes of Asparagus racemosus Willd. Agric Res 8:27-35

Claydon N, Grove JF, Pople MJ (1979) Insecticidal secondary metabolic products from the entomogenous fungus Fusarium larvarum. In Vertebr Pathol 33:364-367

Cojocaru M, Droby S, Glotter E, Goldman A, Gottlieb HE, Jacoby B, Prusky D (1986) 5-(12-Heptadecenyl)-resorcinol, the major component of the antifungal activity in the peel of mango fruit. Phytochemistry 25:1093-1095

Cole MD, Bridge PD, Dellar JE, Fellows LE, Cornish MC, Anderson JC (1991) Antifungal activity of neo-clerodane diterpenoids from Scutellaria. Phytochemistry 30:1125-1127

Conn KL, Browne LM, Tewari JP, Ayer WA (1994) J Plant Biochem Biotechnol 3:125

Copping LG (2004) The manual of biocontrol agents, 3rd edn. BCPC Publications, Alton, p 702

Corcuff R, Mercier J, Tweddell R, Arul J (2011) Effect of water activity on the production of volatile organic compounds by Muscodor albus and their effect on three pathogens in stored potato. Fungal Biol 115:220-227

Cordelier S, Ruffray P, Fritg B, Kauffmann S (2003) Biological and molecular comparison between localized and systemic acquired resistance induced in tobacco by Phytophthora megasperma glycoprotein elicitin. Plant Mol Biol 51:109-118

Costa FG, Zucchi TD, de Melo IS (2013) Biological control of phytopathogenic fungi by endophytic actinomycetes isolated from maize (Zea mays L). Braz Arch Biol Technol 56(6):948-955

Cowan MM (1999) Plant products as antimicrobial agents. Clin Microbiol Rev 12:564-582

Coxon DT (1980) Identification of three hydroxyflavan phytoalexins from daffodil bulbs. Phytochemistry 19:889891

Coxon DT (1982) Phytoalexins from other plant families. In: Bailey JA, Mansfield JW (eds) Phytoalexins. Blackie, Glasgow/London, pp 106-132

Crawford DL, Lynch JM, Whipps JM, Ousley MA (1993) Isolation and characterization of actinomycete antagonists of a fungal root pathogen. Appl Environ Microbiol 59(11):3889-3905

Cuenca-Estrella M, Mellado E, Diaz-Guerra TM, Monzon A, Rodriguez-Tudela JL (2000) Susceptibility of fluconazole-resistant clinical isolates of Candida spp. to echinocandin LY303366, itraconazole and amphotericin B. J Antimicrob Chemother 46:475-477

Curvêlo CRS, Rodrigues FA, Silva LC, Nascimento KJT, Berger PG (2013) Biochemical defense mechanisms in cotton plants against Ramularia leaf spot mediated by silicon. Bragantia $72: 41-51$

Dabur R, Chhillar AK, Yadav V, Kamal PK, Gupta J, Sharma GL (2005) In vitro antifungal activity of 2-(3,4-dimethyl-2,5-dihydro-1H-pyrrol-2-yl)-1-methylethyl pentanoate, a dihydro - pyrrole derivative. J Med Microbiol 54:549-552

Dahiya JS, Rimmer SR (1988) Phytoalexin accumulation in tissues of Brassica napus inoculated with Leptosphaeria maculans. Phytochemistry 27:3105-3107

Daisy BH, Strobel GA, Castillo U, Ezra D, Sears J, Weaver DK, Justin B (2002) Naphthalene, an insect repellent, is produced by Muscodor vitigenus, a novel endophytic fungus. Runyon Microbiol 148:3737-3741

Dan Y, Liu HY, Gao WW, Chen SL (2010) Activities of essential oils from Asarum heterotropoides var. mandshuricum against five phytopathogens. Crop Prot 29:295-299

Dávila MD, Gallegos MG, Castillo HFD, Fuente CYM, Olivas FA, Siller CM (2016) Antagonist actinomycetes metabolites against plant pathogens fungi of agricultural importance. J Sci Res Stud 3(11):224-230 
Deice Raasch-Fernandes L, Bonaldo SM, de Jesus Rodrigues D, Magela Vieira-Junior G, Regina Freitas Schwan-Estrada K, Rocco da Silva C (2019) Induction of phytoalexins and proteins related to pathogenesis in plants treated with extracts of cutaneous secretions of southern Amazonian Bufonidae amphibians. PLoS One 14(1): e0211020

Dayan FE, Cantrell CL, Duke SO (2009) Natural products in crop protection. Bioorg Med Chem 17:4022-4034

de Bertoldi C, de Leo M, Braca A, Ercoli L (2009) Bioassay-guided isolation of allelochemicals from Avena sativa L.: allelopathic potential of flavone C-glycosides. Chemoecology 19:169-176

De Corato U, Salimbeni R, De Pretis A, Avella N, Patruno G (2017) Antifungal activity of crude extracts from brown and red seaweeds by a supercritical carbon dioxide technique against fruit postharvest fungal diseases. Postharvest Biol Technol 131:16-30

de Vasconcellos RLF, Cardoso EJBN (2009) Rhizospheric streptomycetes as potential biocontrol agents of Fusarium and Armillaria pine rot and as PGPR for Pinus taeda. BioControl 54:807

DeBoer C, Meulman PA, Wnuk RJ, Peterson DH (1970) Geldanamycin, a new antibiotic. J Antibiot (Tokyo) 23:442-447

Defago G, Kern H (1988) Induction of Fusarium solani mutants insensitive to tomatine, their pathogenicity and aggressiveness to tomato fruits and pea plants. Physiol Plant Pathol 22:29-37

Delaunois B, Cordelier S, Conreux A, Clément C, Jeandet P (2009) Molecular engineering of resveratrol in plants. Plant Biotechnol J 7:2-12

Deng Y, Nicholson RA (2005) Antifungal properties of surangin B, a coumarin from Mammea longifolia. Planta Med 71:364-365

Deora GS, Guhil N (2015) Phytochemical analysis and antifungal activity of moss Bryum cellulare against some phytopathological fungi. Int J Pharm Sci Res 6(2):688-691

Deora GS, Guhil N (2016) Studies on antifungal potential of Bryum cellulare against spore germination of fungus Curvularia lunata. Int J Pharm Sci Res 7(1):353-357

Deora GS, Jain NS (2008) In vitro antifungal activity of Plagiochasma appendiculatum against Alternaria solani. J Pure Applied Microbiol 2:569-572

Deora GS, Suhalka D (2017) Evaluation of bryophyte for green fungicides as alternative treatment to control plant pathogen. Int J Pharmacog Phytochem Res 9(10): 1373-1379

Deverall BJ (1982) Introduction. In: Bailey JA, Mansfield JW (eds) Phytoalexins. Blackie, Glasgow/London, pp 19-20

Devys M, Barbier M (1990) Oxidative ring contraction of the phytoalexin cyclobrassinin: a way to brassilexin. J Chem Soc Perkin Trans I:2856

Devys M, Barbier M, Loiselet I, Rouxel T, Sarniguet A, Kollmann A, Bousquet J (1988) Brassilexin, a novel sulphur-containing phytoalexin from Brassica juncea L., (cruciferae). Tetrahedron Lett 29:6447

Dewi TK, Dwi A, Antonius S (2017) Secondary metabolites production by actinomycetes and their antifungal activity. ICBS conference proceedings, international conference on biological science KnE. Life Sci 3:256-264

Dey A, De JN (2011) Antifungal bryophytes: a possible role against human pathogens and in plant protection. Res J Bot 6(4):129-140

Dhatwalia VK, Sati OP, Tripathi MK, Kumar A (2009) Isolation, characterization and antimicrobial activity at diverse dilution of wheat puroindoline protein. World J Agric Sci 5:297-300

Dhingra OD, Mizubuti ESG, Napoleao IT, Jham G (2001) Free fatty acid accumulation and quality loss of stored soybean seeds invaded by Aspergillus ruber. Seed Sci Technol 29:193-203

Dixon RA, Lamb CJ (1999) Molecular communication in interactions between plants and microbial pathogens. Annu Rev Plant Physiol Plant Mol Biol 41:229367

Dochhil H, Dkhar MS, Barman D (2013) Seed germination enhancing activity of endophytic Streptomyces isolated from indigenous ethno-medicinal plant Centella asiatica. Int J Pharm Bio Sci 4(1):256-262

Dos Anjos ÉCT, Cavalcante UMT, Gonçalves DMC, Pedrosa EMR, Santos VF, Maia LC (2010) Interactions between an arbuscular mycorrhizal fungus (Scutellospora heterogama) and the 
root-knot nematode (Meloidogyne incognita) on sweet passion fruit (Passiflora alata). Braz Arch Biol Technol 53:801-809

Draz IS, Elkhwaga AA, Elzaawely AA, El-Zahaby HM, Anter Ismail AW (2019) Application of plant extracts as inducers to challenge leaf rust of wheat. Egypt J Biol Pest Control 29:6

Du R, Liu J, Sun P, Li H, Wang J (2017) Inhibitory effect and mechanism of Tagetes erecta L. fungicide on Fusarium oxysporum f. sp. niveum. Sci Rep 7(14442):1-13

Dukare AS, Prasanna R, Dubey SC, Nain L, Chaudhary V, Singh R, Saxena AK (2011) Evaluating novel microbe amended composts as biocontrol agents in tomato. Crop Prot 30:436-442

Duke (2004) Biological activity summary for cocoa (Theobroma cacao L.). J Med Food 3:115-119

Durango D, Pulgarin N, Echeverri F, Escobar G, Quiñones W (2013) Effect of salicylic acid and structurally related compounds in the accumulation of phytoalexins in cotyledons of common bean (Phaseolus vulgaris L.) cultivars. Molecules 18:10609-10628

Echeverri F, Torres F, Quiñones W, Escobar G, Archbold R (2012) Phenylphenalenone phytoalexins, will they be a new type of fungicide? Phytochem Rev 11:1-12

Edris AE, Farrag ES (2003) Antifungal activity of peppermint and sweet basil essential oils and their major aroma constituents on some plant pathogenic fungi from the vapor phase. Nahrung 47:117-121

El-Gendy MMA, EL-Bondkly AMA (2010) Production and genetic improvement of a novel antimycotic agent, saadamycin, against dermatophytes and other clinical fungi from endophytic Streptomyces sp. Hedaya48. J Ind Microbiol Biotechnol 37:831-841

El-Shatoury S, El-Kraly O, El-Kazzaz W, Dewedar A (2009) Antimicrobial activities of Actinomycetes inhabiting Achillea Fragrantissima (Family: Compositae). Egypt J Nat Toxins $6(2): 1-15$

El-Tarabily KA (2003) An endophytic chitinase-producing isolate of Actinoplanes missouriensis, with potential for biological control of root rot of lupine caused by Plectosporium tabacinum. Aust J Bot 51:257-266

El-Tarabily KA, Hardy GESJ, Sivasithamparam K (2010) Performance of three endophytic actinomycetes in relation to plant growth promotion and biological control of Pythium aphanidermatum, a pathogen of cucumber under commercial field production conditions in the United Arab Emirates. Eur J Plant Pathol 128:527-539

El-Tarabily KA, Sivasithamparam K (2006) Nonstreptomycete actinomycetes as biocontrol agents of soil-borne fungal plant pathogens and as plant growth promoters. Soil Biol Biochem 38:1505-1520

Endo K, Kanno E, Oshima Y (1990) Structures of antifungal diarylheptenones, gingerenones A, B, C and isogingerenone B, isolated from the rhizomes of Zingiber officinale. Phytochemistry 29:797

Ezra D, Castillo UF, Strobel GA, Hess WM, Porter H, Jensen JB, Condron MAM, Teplow DB, Sears J, Maranta M, Hunter M, Weber B, Yaver D (2004a) Coronamycins, peptide antibiotics produced by a verticillate Streptomyces sp. (MSU-2110) endophytic on Monstera sp. Microbiology 150:785-793

Sánchez-Ortiz BL, Sánchez-Fernández RE, Duarte G, Lappe-Oliveras P, Macías-Rubalcava ML (2016) Antifungal, anti-oomycete and phytotoxic effects of volatile organic compounds from the endophytic fungus Xylaria sp. strain PB3f3 isolated from Haematoxylum brasiletto. J Appl Microbiol 120(5):1313-1325

Ezra D, Hess WM, Strobel GA (2004b) New endophytic isolates of Muscodor albus, a volatileantibiotic-producing fungus. Microbiology 150:4023-4031

Ezra D, Strobel GA (2003) Effect of substrate on the bioactivity of volatile antimicrobials produced by Muscodor albus. Plant Sci 165:1229-1238

Fernández RES, Diaz D, Duarte G, Oliveras PS, Sánchez S, Macías-Rubalcava ML (2016) Antifungal volatile organic compounds from the Endophyte Nodulisporium sp. strain GS4d2II1a: a qualitative change in the intraspecific and interspecific interactions with Pythium aphanidermatum. Microb Ecol 71(2):347-364 
Feliziani E, Landi L, Romanazzi G (2015) Preharvest treatments with chitosan and other alternatives to conventional fungicides to control postharvest decay of strawberry. Carbohydr Polym 132:111-117

Franich RA, Gadgil PD, Shain L (1983) Fungistatic effects of Pinus radiata needle epicuticular fatty and resin acids on Dothistroma pini. Physiol Plant Pathol 23:183-195

Frankmölle WP, Larsen LK, Caplan FR, Patterson GML, Knubel G, Levine IA, Moore RE (1992) Blue-green alga Anabaena laxa. I isolation and biological properties. J Antibiot (Tokyo) 45:1451-1457

Friend J (2016) Plant Phenolics, lignification. Prog Phytochem 7:197

Fritz M, Jakobsen I, Lyngkjaer MF, Thordal Christensen H, Kühnemann P (2006) Arbuscular mycorrhiza reduces susceptibility of tomato to Alternaria solani. Mycorrhiza 16:413-419

Fu J, Zhou Y, Li H-F, Ye Y-H, Guo J-H (2011) Antifungal metabolites from Phomopsis sp. By254, an endophytic fungus in Gossypium hirsutum. Afr J Microbiol Res 5:1231-1236

Fukuta $\mathrm{M}$ et al (2007) Comparative efficacies in vitro of antibacterial, fungicidal, antioxidant, and herbicidal activities of momilactones a and B. J Plant Interact 2:245251

Gahotri D, Chaturvedi P (2011) Antifungal and antibacterial potential of methanol and chloroform extracts of Marchantia polymorpha L. Arch Phytopathol Plant Protect 44:736-731

Galeotti F, Barile E, Curir P, Dolci M, Lanzotti V (2008) Flavonoids from carnation (Dianthus caryophyllus) and their antifungal activity. Phytochem Lett 1:44-48

Gamalero E, Pivato B, Bona E, Copetta A, Avidano L, Lingua G (2010) Interactions between a fluorescent pseudomonad, an arbuscular mycorrhizal fungus and a hypo virulent isolate of Rhizoctonia solani affect plant growth and root architecture of tomato plants. Plant Biosyst 144:582-591

Gangwar M, Dogra S, Gupta UP, Kharwar RN (2014) Diversity and biopotential of endophytic actinomycetes from three medicinal plants in India. Afr J Microbiol Res 8(2):184-191

Gangwar M, Kaur N, Saini P, Kalia A (2015) The diversity, plant growth promoting and antimicrobial activities of endophytic actinomycetes isolated from Emblica officinalis Gaertn. Int J Adv Res 3(4):1062-1071

Garc1a-Mier L, RG G-G'1, VM M'n-O'n, Verduzco-Cuellar BR, TorresPacheco I (2013) Agriculture and bioactives: achieving both crop yield and phytochemicals. Int J Mol Sci 14:4203-4222

Gayathri P, Muralikrishnan V (2013) Isolation and characterization of Endophytic Actinomycetes from mangrove plant for antimicrobial activity. Int J Curr Microbiol App Sci 2(11):78-89

Geigert J (1973) Two phytoalexins from sugar beet (Beta vulgaris) leaves. Tetrahedron 29:2703-2706

Genovese G, Leitner S, Minicante SA, Lass-Florl C (2013) The Mediterranean red alga Asparagopsis taxiformis has antifungal activity against Aspergillus species. Mycoses 56:516-519

Gholami M, Khakvar R, Niknam G (2014) Introduction of some new endophytic bacteria from Bacillus and Streptomyces genera as successful biocontrol agents against Sclerotium rolfsii. Arch Phytopathol Plant Protect 47(1):122-130

Goa KI, Barradell LB (1995) Fluconazole: an update of its pharmacodynamic and pharmacokinetic properties and therapeutic use in major superficial and systemic mycoses in immunocompromised patients. Drugs 50:658-690

Grayer RJ, Kokubun T (2001) Plant-fungal interactions: the search for phytoalexins and other antifungal compounds from higher plants. Phytochesmistry 56:253-263

Greger H, Hofer O, Kiihlig H, Wurz G (1992) Sulfur containing cinnamides with antifungal activity from Glycosmis cyanocarpa. Tetrahedron 48:1209-1218

Gross D, Porzel A, Schmidt J (1994) Phytoalexin emit Indolstruktur aus kohlrabi (Brassica oleracea var. gongylodes). Z Naturforsch 49c:281-285

Grosskinsky DK, Naseem M, Abdelmoshem UA, Plickert N, Engelke T, Griebel T, Zeier J, Novak O, Strand M, Pfeifhofer H (2011) Cytokinins mediate resistance against pseudomonas syringae in tobacco through increased antimicrobial phytoalexin synthesis independent of salicylic acid signaling. Plant Physiol 2011(157):815-830

Grove JF, Pople MJ (1979) Metabolic products of Fusarium larvarum fuckel. The fusarentins and the absolute configuration of monocerin. Chem Soc Perkin Trans 1 (1979):2048-2051 
Guimarães SS, Mazaro SM, Freddo ÁR, Wagner Júnior A (2015) Potential of horsetail (Equisetum sp.) preparations in the synthesis of defense metabolites in soy (Glycine max L.) cotyledons and the effect on the growth of Rhizoctonia solani Kuhn, in vitro. Rev Bras Plantas Med 17:143-149

Güimil S, Chang HS, Zhu T, Sesma A, Osbourn A, Roux C, Ioannidis V, Oakeley EJ, Docquier M, Descombes P, Briggs SP, Paszkowski U (2005) Comparative transcriptomics of rice reveals an ancient pattern of response to microbial colonization. Proc Natl Acad Sci 102:8066-8070

Guo L, Wu JZ, Han T, Cao T, Rahman K, Qin LP (2008) Chemical composition, antifungal and antitumor properties of ether extracts of Scapania verrucosa Heeg. and its endophytic fungus Chaetomium fusiformis. Molecules 13:2114-2125

Gurgel LA, Sidrim JJC, Martins DT, Filho CV, Rao VS (2005) In vitro antifungal activity of dragon's blood from Croton urucurana against dermatophytes. J Ethnopharmacol 97:409-412

Gutjahr C, Paszkowski U (2013) Multiple control levels of root system remodelling in arbuscular mycorrhizal symbiosis. Plant Sci 4:204

Gwa VI, Nwankiti AO, Ekefan EJ (2018) Antifungal effect of five aqueous plant extracts on Mycelial growth of Penicillium Expansum isolated from rotted yam tubers in storage. Acta Sci Agric 2(6)

Hage-Ahmed K, Moyses A, Voglgruber A, Hadacek F, Steinkellner S (2013) Alterations in root exudation of intercropped tomato mediated by the arbuscular mycorrhizal fungus Glomus mosseae and the soil borne pathogen Fusarium oxysporum f.sp. lycopersici. J Phytopathol 161:763-773

Hahn MG, Darvill AG, Albersheim P (2008) Host-pathogen interactions: XIX. The endogenous elicitor, a fragment of a plant cell wall polysaccharide that elicits phytoalexin accumulation in soybeans. Plant Physiol 68:1161-1169

Hammer EC, Pallon J, Wallander H, Olsson PA (2011) Tit for tat? A mycorrhizal fungus accumulates phosphorus under low plant carbon availability. FEMS Microbiol Ecol 76:236-244

Harding VK, Heale JB (1981) The accumulation of inhibitory compounds in the induced resistance response of carrot root slices to Botrytis cinerea. Physiol Plant Pathol 18:7-15

Har-Nun N, Meyer AM (1990) Cucurbitacins protect cucumber tissue against infection by Botrytis cinerea. Phytochemistry 29:787-791

Harper JK, Arif AM, Ford EJ, Strobel GA, Porco JA, Tomer DP, KL O\&N, Grant DM (2003) Pestacin: a 1,3-dihydro isobenzofuran from Pestalotiopsis microspora possessing antioxidant and antimycotic activities. Tetrahedron 59:2471-2476

Harris JE, Dennis C (1977) The effect of post-infectional potato tuber metabolites and surfactants on zoospores of Oomycetes. Physiol Plant Pathol 11:163-169

Hartmann G, Niehaus F (1974) The isolation of xanthoxylin from the bark of Phytophthora and Hendersonula-infected Citrus lemon and its fungitoxic effect. Phytopathology 81:97-113

Hasegawa M, Mitsuhara I, Seo S, Okada K, Yamane H, Iwai T, Ohashi Y (2014) Analysis on blast fungus-responsive characters of a flavonoid phytoalexin sakuranetin; accumulation in infected rice leaves, antifungal activity and detoxification by fungus. Molecules 19:11404-11418

Hawksworth DL (1991) The fungal dimension of biodiversity: magnitude, significance, and conservation. Mycol Res 95:641-655

Hawksworth DL (2001) The magnitude of fungal diversity: the $1 \pm 5$ million species estimate revisited. Mycol Res 105:1422-1431

Hayakawa M, Nonomura H (1987) Efficacy of artificial humic acid is a selective nutrient in HV agar used for the isolation of actinomycetes. J Ferment Technol 65:609-616

He XZ, Dixon RA (2000) Genetic manipulation of isoflavone 7-O-methyltransferase enhances biosynthesis of 4'-O-methylated isoflavonoid phytoalexins and disease resistance in alfalfa. Plant Cell 12:1689-1702

Herger G, Klingauf F, Mangold D, Pommer EH, Scheter M (1988) Die Wirkung von Auszigen aus dem Sachalin- Staudenknoterich Reynoutria sachalinensis (F. Schmidt) Nakai gegen Plizkrankheiten, insbesondere Echte Mehltauplize. Nachrchtenblatt der Deutsche Pflanzenschutzdienst 40:56-60 
Homma Y, Kato Z, Hirayama F, Konno K, Shirahama H, Suzui T (1989) Production of antibiotics by Pseudomonas cepacia as an agent for biological control of soilborne plant pathogens. Soil Biol Biochem 21:723-728

Hoof LV, Berghe DAV, Vlietinck AJ (2008) Screening of poplar trees for antibacterial, antifungal and antiviral activity. Biol Plant 22:265-273

Howell CR, Stipanovic RD (1980) Suppression of Pythium ultimum induced damping -off of cotton seedlings by Pseudomonas fluorescens and its antibiotic, pyoluterin. Phytopathology 70:712-715

Huang LD, Backhouse D (2004) Effects of Fusarium species on defence mechanisms in sorghum seedlings. N Z Plant Protection 57:121-124

Huang R, Li GQ, Zhang J, Yang L, Che HJ, Jiang DH, Huang HC (2011) Control of post harvest botrytis fruit rot of strawberry by volatile organic compounds of Candida intermedia. Phytopathology 101:859-869

Huang WY, Cai YZ, Hyde KD, Corke H, Sun M (2008) Biodiversity of endophytic fungi associated with 29 traditional Chinese medicinal plants. Fungal Divers 33:61-75

Huffaker A et al (2011) Novel acidic sesquiterpenoids constitute a dominant class of pathogeninduced phytoalexins in maize. Plant Physiol 56:2082-2097

Ibraheem IB, Hamed SM, Abd elrhman AA, Mohamed Farag F, Abdel-Raouf N (2017) Antimicrobial activities of some brown macroalgae against some soil borne plant pathogens and in vivo management of Solanum melongena root diseases. Aust J Basic Appl Sci 11:157-168

Ibrahima M, Kaushik N, Sowemimoa A, Chhipab H, Koekemoerc T, Venterc M, Odukoyaa OA (2017) Antifungal and antiproliferative activities of endophytic fungi isolated from the leaves of Markhamia tomentosa. Pharm Biol 55(1):590-595

Igarashi Y (2004) Screening of novel bioactive compounds from plant-associated actinomycetes. Actinomycetology 18:63-66

Igarashi Y, Iida T, Sasaki T, Saito N, Yoshida R, Furumai T (2002) Isolation of actinomycetes from live plants and evaluation of anti phytopathogenic activity of their metabolites. Actinomycetology 16:9-13

Inderiati S, Franco CMM (2008) Isolation and Identification of Endophytic Actinomycetes and their Antifungal Activity. J Biotech Res Trop Reg 1. (Spl. Ed.)

Ingham JL (1982) Phytoalexins from the Leguminosae. In: Bailey JA, Mansfield JW (eds) Phytoalexins. Blackie, Glasgow/London, pp 21-80

Ingham JL, Tahara S, Harborne JB (1983) Fungitoxic isoflavones from Lupinus albus and other Lupinus species. Z Naturforsch 38c:194-200

Isono K, Suzuki S (1979) The polyoxins: pyrimidine nucleoside peptide antibiotics inhibiting fungal cell wall biosynthesis. Heterocycles 13:133

Karneda Y, Asano N, Yamaguchi T, Matsui K (1987) Validoxylamines as trehalase inhibitors. Anrihiot (Tokyo) 40:563-565

Islam TM, Hashidoko Y, Deora A, Ito T, Tahara S (2005) Suppression of damping-off disease in host plants by the rhizoplane bacterium Lysobacter sp. strain SB-K88 is linked to plant colonization and antibiosis against soilborne peronosporomycetes. Appl Environ Microbiol 71:3786-3796

Ismail A, Salah KBH, Ahmed M, Mastouri M, Bouraoui A, Aouni M (2014) Antibacterial and antifungal activities of brown alga Zonaria tournefortii (JV Lamouroux). Allelopath J 34:143-153

Ivantiskaya LP, Singal SM, Bibikova MV, Vostrov SN (1978) Direct isolation of Micromonospora on selective media with gentamicin. Antibiot 23:690-692

Jambunathan R, Butler LG, Bandsyopadkyay R, Mughogho K (1986) Polyphenol concentrations in grain, leaf and callus tissues of mold-susceptible and mold-resistant sorghum cultivars. J Agric Food Chem 34:425-429

Jardim CM, Jham GN, Dhingra OD, Freire MM (2008) Composition and antifungal activity of the essential oil of the Brazilian Chenopodium ambrosioides L. J Chem Ecol 34(9):1213-1218

Jaulneau V, Lafitte C, Jacquet C, Fournier S, Salamagne S, Briand X, Esquerré-Tugayé M-T, Dumas B (2010) Ulvan, a sulfated polysaccharide from green algae, activates plant immunity through the jasmonic acid signaling pathway. J Biomed Biotechnol 2010:525291 
Jeandet P, Clément C, Courot E, Cordelier S (2013) Modulation of phytoalexin biosynthesis in engineered plants for disease resistance. Int J Mol Sci 14:14136-14170

Jeandet P, Delaunois B, Aziz A, Donnez D, Vasserot Y, Cordelier S, Courot E (2012) Metabolic engineering of yeast and plants for the production of the biologically active hydroxystilbene, resveratrol. J Biomed Biotechnol 2012:1-14

Jeandet P, Delaunois B, Conreux A, Donnez D, Nuzzo V, Cordelier S, Clément C, Courot E (2010) Biosynthesis, metabolism, molecular engineering and biological functions of stilbene phytoalexins in plants. Biofactors 36:331-341

Jeandet P, Hébrard C, Deville MA, Cordelier S, Dorey S, Aziz A, Crouzet J (2014) Deciphering the role of phytoalexins in plant-microorganism interactions and human health. Molecules 19(11):18033-18056

Jimenez LD, Ayer WA, Tewari JP (1997) Phytoalexins produced in the leaves of Capsella bursapastoris (shepherd's purse). Phytoprotection 78:99-103

Johnson C, Brannon DR, Kuc J (1973) Xanthotoxin: a phytoalexin of Pastinaca sativa root. Phytochemistry 12:2961-2962

Jung SC, Martinez-Medina A, Lopez-Raez JA, Pozo MJ (2012) Mycorrhiza-induced resistance and priming of plant defenses. J Chem Ecol 38:651-664

Kafur A, Khan AB (2011) Isolation of endophytic actinomycetes from Catharanthus roseus (L.) G. Don leaves and their antimicrobial activity. Iranian. J Biotechnol 9(4):301-306

Karagiannidis N, Bletsos F, Stavropoulos N (2002) Effect of Verticillium wilt (Verticillium dahliae Kleb.) and mycorrhiza (Glomus mosseae) on root colonization, growth and nutrient uptake in tomato and eggplant seedlings. Sci Hortic 94:145-156

Keen NT, Littlefield LJ (1975) The possible association of phytoalexins with resistant gene expression in flax to Melampsora lini. Physiol Plant Pathol 14:275280

Khallil AM, Daghman IM, Fady AA (2015) Antifungal potential in crude extracts of five selected brown seaweeds collected from the western Libya coast. J Microbiol Mod Tech 1:103

Khan MS, Ahmad I (2011) In vitro antifungal, anti-elastase and anti-keratinase activity of essential oils of Cinnamomum-, Syzygium- and Cymbopogon-species against Aspergillus fumigatus and Trichophyton rubrum. Phytomedicine 19:48-55

Kim SI, Roh JY, Kim DH, Lee HS, Ahn YJ (2003) Insecticidal activities of aromatic plant extracts and essential oils against Sitophilus Oryzae and Callosobruchus chinensis. J Stored Prod Res 39(3):293-303

Kim YM, Lee CH, Kim HG, Lee HS (2004) Anthraquinones isolated from Cassia tora (Leguminosae) seed show an antifungal property against phytopathogenic fungi. J Agric Food Chem 52:6096-6100

Kimura M, Yamaguchi I (1996) Recent development in the use of Blasticidin S, a microbial fungicide, as a useful reagent in molecular biology. Pestic Biochem Physiol 56:243

Klarzynski O, Plesse B, Joubert JM, Yvin JC, Kopp M, Kloareg B, Fritig B (2000) Linear b-1,3 glucans are elicitors of defense responses in tobacco-France. Plant Physiol 124:1027-1037

Kloepper JW, Ryu CM, Zhang S (2004) Induce systemic resistance and promotion of plant growth by Bacillus spp. Phytopathology 94:1259-1266

Kobayashi K, Nishino C, Tomita H, Fukushima M (1987) Antifungal activity of pisiferic acid derivatives against the rice blast fungus. Phytochemistry 26:3175-3179

Koga J et al (1997) Functional moiety for the antifungal activity of phytocassane E, a diterpene phytoalexin from rice. Phytochemistry 44:249-253

Kokubun T, Harborne JB (1995) Phytoalexin induction in the sapwood of plants of the Maloideae (Rosaceae): biphenyls or dibenzofurans. Phytochemistry 40:1649-1654

Koumoutsi A, Chen XH, Henne A, Liesegang H, Gabriele H, Franke P, Vater J, Borris R (2004) Structural and functional characterization of gene clusters directing non-ribosomal synthesis of bioactive lipopeptides in Bacillus amyloliquefaciens strain FZB42. J Bacteriol 186:1084-1096

Kraiczy P, Haase U, Gencic S, Flindt S, Anke T, Brandt U, von Jagow G (1996) Eur J Biochem 235:54

Krishna Kishore G, Pande S, Harish S (2007) Evaluation of essential oils and their components for broad-spectrum antifungal activity and control of late leaf spot and crown rot diseases in peanut. Plant Dis 91(4):375-379 
Krzaczkowski L, Wright M, Gairin JE (2008) Bryophytes, a potent source of drugs for tomorrow's medicine? Med Sci 24:947-953

Krzyzaniak Y, Trouvelot S, Negrel J, Cluzet S, Valls J, Richard T, Bougaud A, Jacquens L, Klinguer A, Chiltz A, Adrian M, Héloir M-C (2018) A plant extract acts both as a resistance inducer and an oomycide against grapevine downy mildew. Front Plant Sci 9:1085

Küster E (1959) Outline of a comparative study of criteria used in characterization of the actinomycetes. Int Bull Bacteriol Nomencl Taxon 9:97-104

Küster E, Williams ST (1964) Selection of media for isolation of Streptomycetes. Nature 202:928-929

Kuc J (1982) Phytoalexins from the Solanaceae. In: Bailey JA, Mansfield JW (eds) Phytoalexins. Blackie, Glasgow/London, pp 81-105

Kudalkar P, Strobel G, Ul-Hassan SR, Geary B, Sears J (2012) Muscodor sutura, a novel endophytic fungus with volatile antibiotic activities. Mycoscience 53:319-325

Kumar S, Kaushik N (2013) Endophytic fungi isolated from oil-seed crop Jatropha curcas produces oil and exhibit antifungal activity. PLoS One 8(2):e56202

Kumar S, Kaushik N, Proksch P (2013) Identification of antifungal principle in the solvent extract of an endophytic fungus Chaetomium globosum from Withania somnifera. Springerplus 2(1):37

Kumar S, Kaushik N, Edrada-Ebel R, Ebel R, Proksch P (2011) Isolation, characterization, and bioactivity of endophytic fungi of Tylophora indica. World J Microbiol Biotechnol 27:571-577

Mends MT, Yu E, Strobel GA, Riyaz-Ul-Hassan S, Booth E, Geary B, Sears J, Taatjes CA, Hadi MZ (2012) An endophytic Nodulisporium sp. producing volatile organic compounds having bioactivity and fuel potential. J Pet Environ Biotechnol 03:117

Kumar V, Karunaratne V, Sanath MR, Meegalle K, Macleod JK (1990) Two fungicidal phenylethanones from Euodia lunu-ankenda root bark. Phytochemistry 29:243-245

Labbe C, Faini F, Villagram C, Coll J, Rycroft DS (2005) Antifungal and insect antifeedant 2-phenylethanol esters from the liverwort Balantiopsis cancellata from Chile. J Agric Food Chem 53:247-249

Lacey LA, Horton DR, Jones DC, Headrick HL, Neven LG (2009) Efficacy of the biofumigant fungus Muscodor albus (Ascomycota: Xylariales) for control of codling moth (Lepidoptera: Tortricidae) in simulated storage conditions. J Econ Entomol 102(1):43-49

Lacey LA, Neven LG (2006) The potential of the fungus, Muscodor albus, as a microbial control agent of potato tuber moth (Lepidoptera: Gelechiidae) in stored potatoes. J Invertebr Pathol 9:1195-1198

Lago JH, Ramos CS, Casanova DC, Morandim AA, Bergamo DC, Cavalheiro AJ, Bolzani VS, Furlan M, Guimaraes EF, Young MC, Kato MJ (2004) Benzoic acid derivatives from piper species and their fungitoxic activity against Cladosporium cladosporioides and C. sphaerospermum. J Nat Prod 67:783

Langcake P, Pryce RJ (1976) The production of resveratrol by Vitis vinifera and other members of the Vitaceae as a response to infection or injury. Physiol Plant Pathol 9:77-86

Larsen J, Bodker L (2003) Interactions between pea root-inhabiting fungi examined using signature fatty acids. New Phytol 149:487-493

Leclere V, Bechet M, Adam A, Guez JS, Wathelet B, Ongena M, Thonart P, Gancel F, Chollet-Imbert M, Jacques P (2005) Mycosubtilin overproduction by Bacillus subtilis BBG100 enhances the organism's antagonistic and biocontrol activities. Appl Environ Microbiol 71:4577-4584

Lee CW et al (1999) Momilactones a and B in rice straw harvested at different growth stages. Biosci Biotechnol Biochem 63:1318-1320

Lee HB, Lee HK, Ahn YJ (2003) Antibacterial activity of oriental medicinal plant extracts toward Helicobacter pylori. Agric Chem Biotechnol 46:97-99

Lee SO, Kim HY, Choi GJ, Lee HB, Jang KS, Choi YH (2009) Mycofumigation with Oxyporus latemarginatus EF069 for control of postharvest apple decay and Rhizoctonia root rot on moth orchid. J Appl Microbiol 106:1213-1219

Li H, Qing C, Zhang Y, Zhao Z (2005a) Screening for endophytic fungi with antitumour and antifungal activities from Chinese medicinal plants. World J Microbiol Biotechnol 21:1515-1519 
Li JY, Strobel G, Harper J, Lobkovsky E, Clardy J (2000) Cryptocin, a potent tetramic acid antimycotic from the endophytic fungus Cryptosporiopsis cf. quercina. Org Lett 2:767-770

Li S, Zhang Z, Cain A, Wang B, Long M, Taylor J (2005b) Antifungal activity of camptothecin, trifolin, and hyperoside isolated from Camptotheca acuminata. J Agric Food Chem 53:32-37

Liangbin H, Hongbo L, Junliang S, Zeng J (2012) Effect of laminarin on Aspergillus Flavus growth and aflatoxin production. Adv Mater Res 342:1168-1171

Liarzi O, Bar E, Lewinsohn E, Ezra D (2016) Use of the endophytic fungus Daldinia cf. concentrica and its volatiles as bio-control agents. PLoS One 11(12):0168242

Linderman RG (1994) In: Mycorrhizae and plan health. ASA Special Pub. No. 54, Madison

Lioussanne L, Beauregard M, Hamel C et al (2009) Advances in Mycorrhizal science and technology. NRC Research Press, Ottawa

Liu H, Wang J, Zhao J, Lu S, Wang J, Jiang W, Ma Z, Zhou L (2009a) Isoquinoline alkaloids from Macleaya cordata active against plant microbial pathogens. Nat Prod Commun 4:1557-1560

Liu L, Liu S, Chen X, Guo L, Che Y (2009b) Pestalofones A-E, bioactive cyclohexanone derivatives from the plant endophytic fungus Pestalotiopsis fici. Bioorg Med Chem 17:606-613

Liu M, Wang G, Xiao L, Xu A, Liu X, Xu P, Lin X (2014) Bis(2,3-dibromo-4,5-dihydroxybenzyl) ether, a marine algae derived bromophenol, inhibits the growth of Botrytis cinerea and interacts with DNA molecules. Mar Drugs 12:3838-3851

Lopes G, Andrade PB, Valentão P (2015) Screening of a marine algal extract for antifungal activities. Methods Mol Biol 1308:411-420

Lu C, Shen Y (2003) A new macrolide antibiotic with antitumor activity produced by Streptomyces sp. CS, a commensal microbe of Maytenus hookeri. J Antibiot 56(4):415-418

Lu C, Shen Y (2007) A novel ansamycin, naphthomycin k from Streptomyces sp. J Antibiot 60(10):649-653

Lu H, Xou WX, Meng JC, Hu J, Tan RX (2000) New bioactive metabolites produced by Colletotrichum sp., an endophytic fungus in Artemisia annua. Plant Sci 151:67-73

Ludwig W, Klenk HP (2005) Overview: a phylogenetic backbone and taxonomic framework for prokaryotic systematics. In: Brenner DJ, Krieg NR, Staley JT, Garrity GM (eds) Bergey's manual of systematic bacteriology, The Proteobacteria, part A, Introductory essays, vol 2, 2nd edn. Springer, New York, pp 49-65

Mabrouk SS, El-Shayeb NMA, El-Refai AH, Sallam LAR, Hamdy AA (1985) Inhibitory activities of some marine algae on aflatoxin accumulation. Appl Microbiol Biotechnol 22:152-155

Macias RML, Hernandez BBE, Jimenez EM, Gonzalez MC, Glenn AE, Hanlin RT, Hernandez OS, Saucedo GA, Muria GJM, Anaya AL (2008) Naphthoquinone spiroketal with allelochemical activity from the newly discovered endophytic fungus Edenia gomezpompae. Phytochemistry 69(5):1185-1196

Usman MG, Ahmadu T, Adamu JN, Aisha M (2018) Plant disease control: understanding the roles of toxins and phytoalexins in host-pathogen interaction. PJSRR 4(1):54-66

Mahmud H, Hossain I, Ahmad MU (2018) Plant extracts, BAU-biofungicide and fungicides in controlling some important diseases of Rice cv. BRRI Dhan40. Am J Phytomed Clin Ther 6(2):7

Manjunath M, Prasanna R, Nain L, Dureja P, Singh R, Kumar A, Jaggi S, Kaushik BD (2010) Biocontrol potential of cyanobacterial metabolites against damping off disease caused by Pythium aphanidermatum in solanaceous vegetables. Arch Phytopathol Plant Protect 43:666-677

Mann R, Mattner S, Allen D, Porter I, Edwards J (2008) Bioprospecting for endophytes from Australian flora with mycofumigation potential. In: 3rd international biofumigation symposium, CSIRO Discovery Centre, Canberra, Australia 80

Manojlovic NT, Solujic S, Sukdolak S, Milosev M (2005) Antifungal activity of Rubia tinctorum, Rhamnus frangula and Caloplaca cerina. Fitoterapia 76:244-246

Mansfield JW (1999) Antimicrobial compounds and resistance: the role of phytoalexins and antianticipins. In: Slusarenko AJ, RSS F, LC VL (eds) Mechanisms of resistance to plant diseases. Kluwer, Amsterdam

Marston A, Gafner F, Dossagi SF, Hostettmann K (1988) Fungicidal and molluscicidal saponins from Dolichos kilimandscharicus. Phytochemistry 27:1325-1326 
Marston A, Hamburger M, Sordat-Disercns I, Msonthi JD, Hostettmann K (1993) Xanthones from Polygala nyikensis. Phytochemistry 33:809-812

Mathias-Mundy E, McCorkle C (1995) Ethnoveterinary medicine and development: a review of the literature. In: Warren DM, Surrerwer L, Broshenka D (eds) The cultural dimension of indigenous knowledge systems. Intermediate Technology Publications, London

Matiello J, Bonaldo SM (2013) Elicitor activity of phytoalexins in soy and sorghum by extracts and tinctures of medicinal plant species. Rev Bras Plantas Med 15:541-550

Matiello J, Raasch-Fernandes LD, Berber GCM, Trento RM, Bonaldo SM (2016) Synthesis of phytoalexins in soy and sorghum by extracts and tinctures from three forest species. Revista em Agronego 'cio e Meio Ambiente 9:617-633

Matuso A, Yuki S, Nakayama M (1986) Structures of ent-herbertane sesquiterpenoids displaying antifungal properties from the liverwort Herberta adunca. J Chem Soc Perkin Trans 1:701-710

Katoch M, Pull S (2017) Endophytic fungi associated with Monarda citriodora, an aromatic and medicinal plant and their biocontrol potential. Pharm Biol 55(1):1528-1535

Mekuria T, Steiner U, Hindorf H, Frahm JP, Dehne HW (2005) Bioactivity of bryophyte extracts against Botrytis cinerea, Alternaria solani and Phytophthora infestans. J Appl Bot Food Qual 79:89-93

Mercier J, Jiménez JI (2004) Control of fungal decay of apples and peaches by the biofumigant fungus Muscodor albus. Postharvest Biol Technol 31:1-8

Mercier L, Lafitte C, Borderies G, Briand X, Esquerré-Tugayé MT, Fournier J (2001) The algal polysaccharide carrageenans can act as an elicitor of plant defense. New Phytol 149:43-51

Mery BA, Joubert JM, Hoareau A (2013) Laboratoires Goëmar. Parc Technopolitain atalante, Saint-malo Cedex

Meshram V, Gupta M, Saxena S (2015) Muscodor ghoomensis and Muscodor indica: new endophytic species based on morphological features, molecular and volatile organic analysis from Northeast India. Sydowia 67:133-146

Meshram V, Kapoor N, Chopra G, Saxena (2017) Muscodor camphora, a new record from Cinnamomum camphora. Mycosphere 8(4):568-582

Meshram V, Kapoor N, Saxena S (2013) Muscodor kashayum sp. nov. - a new volatile antimicrobial producing endophytic fungus. Mycology 4(4):196-204

Meshram V, Saxena S, Kapoor N (2014) Muscodor strobelii, a new endophytic species from South India. Mycotaxon 128:93-104

Meyer JR, Linderman RG (1986) Response of subterranean clover to dual inoculation with vesicular-arbuscular mycorrhizal fungi and a plant growth-promoting bacterium, Pseudomonas putida. Soil Biol Biochem 18:185-190

Mikkelsen MD et al (2003) Modulation oh CYP79 genes and glucosilate profiles in Arabidopsis by defense pathways. Plant Physiol 131:298-308

Miles DH, Chittawong V, Hedin PA, Kokpol U (1993) Potential agrochemicals from leaves of Wedelia biflora. Phytochemistry 32:1427-1429

Miles OH, Rosa de Medeiros JM, Chittawong Y, Hedin PA, Swithenbunk C, Lidert Z (1991) 30-formyl-20, 40,60-trihydroxydihydrochalcone from Psidium acutangulum. Phytochemistry 30:1131-1132

Miller JD (1995) Fungi and mycotoxins in grain: implications for stored product research. J Stored Prod Res 31:1-16

Mini Priya R (2012) Endophytic actinomycetes from Indian medicinal plants as antagonists to some phytopathogenic fungi. Sci Rep 1(4):259

Mishra PK, Kedia A, Dubey NK (2015) Chemically characterized Cymbopogon martinii (Roxb.) Wats. essential oil for shelf life enhancer of herbal raw materials based on antifungal, antiaflatoxigenic, antioxidant activity and favorable safety profile. Plant Biosyst 150:1313-1322

Mitchell AM, Strobel GA, Moore E, Robison R, Sears J (2010) Volatile antimicrobials from Muscodor crispans, a novel endophytic fungus. Microbiology 156:270-277

Moezelaar R, Braam C, Zomer J, Gorris LGM, Smid EJ (1999) Volatile plant metabolites for postharvest crop protection. In: Lyr H, Russell PE, Dehne HW, Sisler HD (eds) Modern fungicides and antifungal compounds II, 1st edn. Intercept Limited, Andover, pp 453-467 
Monde K, Sasaki K, Shirata A, Takasugi M (1990a) 4-Methoxybrassinin, a sulphur-containing phytoalexin from Brassica oleracea. Phytochemistry 29:1499-1500

Monde K, Sasaki K, Shirata A, Takasugi M (1991) Brassicanal C and two dioxindoles from cabbage. Phytochemistry 30:2915-2917

Monde K, Katsui N, Shirata A, Takasugi M (1990b) Brassicanal A and B, novel sulfur-containing phytoalexins from the Chinese cabbage Brassica campestris L. ssp pekinensis. Chem Lett:209-210

Monde K, Tamura K, Takasugi M, Kobayashi K, Somei M (1994) Dehydro-4methoxycyclobrassinin, a sulfur-containing phytoalexin isolated from turnip Brassica campestris L. ssp. rapa. Heterocycles 38:263-267

Moon SS, Lu Chen J, Moore RE, Patterson GML (1992) Calophycin, a fungicidal cyclic decapeptide from the terrestrial blue-green alga Calothrix fusca. J Organomet Chem 57:1097-1103

Morita Y, Matsumura E, Okabe T, Fukui F, Ohe T, Ishida N, Inamori Y (2004) Biological activity of $\beta$-dolabrin, $\gamma$ - thujaplicin, and 4-acetyltropolone, hinokitiol-related compounds. Biol Pharm Bull 27:1666-1669

Moyne AL, Shelby R, Cleveland TE, Tuzun S (2001) Bacillomycin D: an iturin with antifungal activity against Aspergillus flavus. J Appl Microbiol 90:622-629

Mueller-Riebau F, Berger B, Yegen O (1995) Chemical composition and fungitoxic properties to phytopathogenic fungi of essential oils of selected aromatic plants growing wild in Turkey. J Agric Food Chem 43:2262-2266

Muirhead IF, Deverall BJ (1984) Evaluation of 3, 4-dihydroxybenzaldehyde, dopamine and its oxidation products as inhibitors of Colletotrichum musae (Berk. and Curt.) arx in green banana fruits. Aust J Bot 32:375-382

Mukherjee KP, Saha K, Saha PB, Pal M, Das J (1996) Antifungal activities of the leaf extract of Cassia tora Linn. (Fam. Leguminosae). Phytoter Res 10:521-522

Müller KO, Börger H (1940) Experimentelle Untersuchungen über die Phytophthora Resistenz der Kartoffel. Arb Biol Reichsanst Land Forstwirtsch 23:189-231

Nagata T, Tsushida T, Hamaya E, Enoki N (1985) Camellidins, antifungal saponins isolated from Camellia japonica. Agric Biol Chem 49(4):1181-1186

Naoumkina M, Farag MA, Sumner LW, Tang YH, Liu CJ, Dixon RA (2007) Different mechanisms for phytoalexin induction by pathogen and wound signals in Medicago truncatula. Proc Natl Acad Sci 104:17909-17915

Ng TB, Ye XJ, Wong JH, Fang EF, Chan YS, Pan W, Ye XY, Sze SCW, Zhang KY, Liu F, Wang HX (2011) Glyceollin, a soybean phytoalexin with medicinal properties. Appl Microbiol Biotechnol 90(1):59-68

Nisimura T, Meguro A, Hasegawa S, Nakagawa Y, Shimizu M, Kunho H (2002) An Endophytic Actinomycete, Streptomyces sp. AOK-30, isolated from mountain laurel and its antifungal activity. J Gen Plant Pathol 68:390-397

Ogundare AO, Adetuyi FC, Akinyosoye FA (2006) Antimicrobial activities of Vernonia tenoreana. Afr J Biotechnol 5(18):1663-1668

Olanrewaju OS, Babalola OO (2019) Streptomyces: implications and interactions in plant growth promotion. Appl Microbiol Biotechnol 103:1179-1188

Oliveira CM, Regasini LO, Silva GH, Pfenning LH, Young MCM, Berlinck RGS, Bolzani VS, Araujo AR (2011) Dihydro isocoumarins produced by Xylaria sp. and Penicillium sp., endophytic fungi associated with Piper aduncum and Alibertia macrophylla. Phytochem Lett 4:93-96

Oliveira JSB, Maia AJ, Schwan-Estrada KRF, Bonato CM, Carneiro SMTPG, Picoli MHS (2014) Activation of biochemical defense mechanisms in bean plants for homeopathic preparations. Afr J Agric Res 9:971-981

Om Y, Yamaguchi I, Misato T (1984) Inhibition of protein biosynthesis by mildiomycin, an antimildew substance. Nihon Noyaku Gakkaishi J Pestic Sci 9:317

Omidbeygi M, Barzegar M, Hamidi Z, Naghdibadi H (2007) Antifungal activity of thyme, summer savory and clove essential oils against Aspergillus flavus in liquid medium and tomato paste. Food Control 18(12):1518-1523 
Orole OO, Adejumo TO (2009) Activity of fungal endophytes against four maize wilt pathogens. Afr J Microbiol Res 3(12):969-973

Osman MEH, El-Sheekh MM, Metwally MA, Ismail AA, Ismail MM (2011) Efficacy of some agricultural wastes in controlling root rot of Glycine max L. induced by Rhizoctonia solani. Asian J Plant Pathol 5:16-27

Merriman PR, Price RD, Kollmorgen AJF, Piggott T, Ridge EH (1974) Effect of seed inoculation with Bacillus subtilis and Streptomyces griseus on the growth of cereals and carrots. Aust J Agric Res 25:219-226

Pacher T, Bacher M, Hofer O, Greger H (2001) Stress induced carbazole phytoalexins in Glycosmis species. Phytochemistry 58:129-135

Padmakumar K, Ayyakkannu K (1997) Seasonal variation of antibacterial and antifungal activities of the extracts of marine algae from southern coasts of India. Bot Mar 40:507-515

Park JH, Choi GJ, Lee HB, Kim KM, Jung HS, Lee SW, Jang KS, Cho KY, Kim JC (2005) Griseofulvin from Xylaria sp. Strain F0010, and endophytic fungus of Abies holophylla and its antifungal activity against plant pathogenic fungi. J Microbiol Biotechnol 15:112-117

Parniske M (2008) Arbuscular mycorrhiza: the mother of plant root endosymbiosis. Nat Rev Microbiol 6:763-775

Park MS, Ahn J, Choi GJ, Choi YH, Jang KS, Kim JC (2010) Potential of the volatile producing fungus Nodulisporium sp. CF016 for the control of postharvest diseases of apple. Plant Pathol J 26:253-259

Passari AK, Mishra VK, Saikia R, Gupta VK, Singh BP (2015) Isolation, abundance and phylogenetic affiliation of endophytic actinomycetes associated with medicinal plants and screening for their in vitro antimicrobial biosynthetic potential. Front Microbiol 6:273

Passari AK, Mishra VK, Gupta VK, Saikia R, Singh BP (2016) Distribution and identification of Endophytic Streptomyces species from Schima wallichii as potential biocontrol agents against fungal plant pathogens. Pol J Microbiol 65(3):319-329

Paszkowski U (2006) Mutualism and parasitism: the yin and yang of plant symbioses. Curr Op Plant Biol 9:364-370

Paulert R, Talamini V, Cassolato JEF, Duarte MER, Noseda MD, Smania A, Stadnik MJ (2009) Effects of sulfated polysaccharide and alcoholic extracts from green seaweed Ulva fasciata on anthracnose severity and growth of common bean (Phaseolus vulgaris L.). J Plant Dis Protect 116:263-270

Paulitz TC, Belanger RR (2001) Biological control in greenhouse systems. Annu Rev Phytopathol 39:103-133

Paxton JD (1980) A new working definition of the term "phytoalexin". Plant Dis 64:734

Pedras MSC, Khan AQ (1996) Biotransformation of the Brassica phytoalexin brassicanal A by blackleg fungus. J Agric Food Chem 44:3403-3407

Pedras MSC, Khan AQ, Taylor JL (1997) Phytoalexins from Brassicas: overcoming plants' defenses. ACS Symp Ser 658:155-166

Pedras MSC, Sorensen JL (1998) Phytoalexin accumulation and antifungal compounds from the crucifer wasabi. Phytochemistry 49:1959-1965

Pedras MS, Abdoli A (2017) Pathogen inactivation of cruciferous phytoalexins: detoxification reactions, enzymes and inhibitors. RSC Adv 7:23633-23646

Pejin B, Sabovljević A, Soković M, Glamočlija J, Ćirić A, Vujičić M, Sabovljević M (2012) Antimicrobial activity of Rhodobryum ontariense. Hemijska industrija, Research note, in press, ISSN 0367-598X

Pelaez F, Cabello A, Platas G, Diez MT, del Val AG, Basilio A, Martan I, Vicente F, Bills GF, Giacobbe RA, Schwartz RE, Onishi JC, Meinz MS, Abruzzo GK, Flattery AM, Kong L, Kurtz MB (2000) The discovery of enfumafungin, a novel antifungal compound produced by an endophytic Hormonema species biological activity and taxonomy of the producing organisms. Syst Appl Microbiol 23:333-343

Pezet R, Pont V (1990) Ultrastructural observations of pterostilbene fungitoxicity in dormant conidia of Botrytis cinerea Pers. J Phytopathol 129:29-30 
Pittet A (1998) Natural occurrence of mycotoxins in foods and feeds - an update review. Revue de Medecine Veterinire 49:479-492

Pont V, Pezet R (1990) Relation between the chemical structure and biological activity of hydroxystilbenes against Botrytis cinerea. J Phytopathol 130:1-8

Potterat O, Stoeckli-Evans H, Msonthi JD, Hostettmann K (1987) Two new antifungal naphthoxirene derivatives and their glucosides from Sesamum angolense WELW. Helv Chim Acta 70:1551-1557

Poussio GB, Abro MA, Hajano BA, Khaskheli MI, Rajput AI, Memon SA (2018) Potential of plant extracts and fungicides for managing Fusarium oxysporum f. Sp lycopersici. Pak J Phytopathol 30(01):75-81

Prusky D, Keen NT, Eaks J (1983) Further evidence for the involvement of a pre-formed antifungal compound in the latency of Colletotrichum gloeosporioides on unripe avocado fruits. Physiol Mol Plant Pathol 22:189-198

Purkayastha RP (2017) Progress in phytoalexin research during the past 50 years. In: Handbook of phytoalexin metabolism and action. Routledge, Boca Raton, pp 1-39

Rashad YM, Aseel DG, Hafez EE (2018) Antifungal potential and defense gene induction in maize against Rhizoctonia root rot by seed extract of Ammi visnaga (L.) Lam. Phytopathol Mediterr 57(1):73-88

Ratnayake Bandara BM, Wimalasiri WR (1988) Diterpene alcohols from Croton lacciferus. Phytochemistry 27:225-226

Ratnayake Bandara BM, Hewage CM, Karun-aratne V, Wannigama P, Adikaram NKB (1992) An antifungal chromene from Eupatorium riparium. Phytochemistry 31:1983-1985

Reddy BN, Raghavender CR (2007) Outbreaks of aflatoxicoses in India. Afr J Food Agric Nutr Dev 7(5):1-15

Reuveni M, Tuzun S, Cole JS, Siegel R, Nesmith WC, Kuc J (1987) Removal of duvatrienediols from the surface of tobacco leaves increases their susceptibility to blue mold. Physiol Mol Plant Pathol 30:441

Reymond P, Farmer EE (1998) Jasmonate and salicylate as global signals for defense gene expression. Curr Opin Plant Biol 1:404-411

Righini H, Roberti R, Baraldi E (2018) Use of algae in strawberry management. J Appl Phycol 30:3551-3564

Ristić MD, Duletić-Laušević S, Knežević-Vukčević J, Marin PD, Simić D, Vukojević J, Janaćković P, Vajs V (2000) Antimicrobial activity of essential oils and ethanol natural products from plants and Fungi as fungicides 227 extract of Phlomis fruticosa L. (Lamiaceae). Phytoter Res $14: 267-271$

Rizk MA (2006) Growth activities of the sugar beet pathogens Sclerotium rolfsii Sacc. Rhizoctonia solani Kühn. and Fusarium verticillioides Sacc. Under cyanobacterial filtrates stress. Plant Pathogol J 5:212-215

Roberti R, Galletti S, Burzi PL, Righini H, Cetrullo S, Perez C (2015) Induction of defense responses in zucchini (Cucurbita pepo) by Anabaena sp. water extract. Biol Control 82:61-68

Roberti R, Righini H, Reyes CP, Roberti R, Righini H, Reyes CP (2016) Activity of seaweed and cyanobacteria water extracts against Podosphaera xanthii on zucchini. Ital J Mycol 45

Robeson DJ, Strobel GA (1982) Agric Biol Chem 46:2681-2683

Roby MHH, Sarhana MA, Selima KA, Khalela KI (2013) Antioxidant and antimicrobial activities of essential oil and extracts of fennel (Foeniculum vulgare L.) and chamomile (Matricaria chamomilla L.). Ind Crop Prod 44:437-445

Román M, Fernández I, Wyatt T, Sahrawy M, Heil M, Pozo MJ (2011) Elicitation of foliar resistance mechanisms transiently impairs root association with arbuscular mycorrhizal fungi. J Ecol 99:36-45

Rosello CJ, Sempere FF, Sanz BI, Chiralt BMA, Santamarina SMP (2015) Antifungal activity and potential use of essential oils against Fusarium culmorum and Fusarium verticillioides. J Essent Oil Bear Plants 18(2):359-367

Rungin S, Indanand C, Suttiviriya P, Kruasuwan W, Jaemsaeng R, Thamchaipenet A (2012) Plant growth enhancing effects by a siderophore producing endophytic streptomycete isolated 
from a Thai jasmine rice plant (Oryza sativa L. cv. KDML105). Antonie Van Leeuwenhoek 102:463-472

Sabovljevic A, Sokovic M, Glamoclija J, Citric A, Vujicic M, Pejin B, Sabovljevic M (2011) Bioactivities of extracts from some axenically farmed and naturally grown bryophytes. J Med Plant Res 5:656-671

Sabovljevic A, Sokovic M, Sabovljevic M, Grubisic D (2006) Antimicrobial activity of Bryum argenteum. Fitoterapia 77:144-145

Sadrati N, Daoud H, Zerroug A, Dahamna S, Bouharati S (2013) Screening of antimicrobial and antioxidant secondary metabolites from endophytic fungi isolated from wheat (Triticum durum). J Plant Protect Res 53(2):129-136

Saha S, Walia S, Kumar J, Parmar BS (2010) Structure biological activity relationships in triterpenic saponins: the relative activity of protobassic acid and its derivatives against plant pathogenic fungi. Pest Manag Sci 66:825-831

Sandra AI, Wright CH, Zumoff LS, Steven VB (2001) Pantoea agglomerans strain EH318 produces two antibiotics that inhibit Erwinia amylovora in vitro. Appl Environ Microbiol 67:282-292

Sanzani S, Schena L, Ippolito A (2014) Effectiveness of phenolic compounds against citrus green mould. Molecules 19:12500-12508

Sanzani SM, de Girolamo A, Schena L, Solfrizzo M, Ippolito A, Visconti A (2009) Control of Penicillium expansum and patulin accumulation on apples by quercetin and umbelliferone. Eur Food Res Technol 228:381-389

Savaroglu F, Fylyk Iscen C, Oztopeu-Vatan P, Kabadere S, Ilhan S, Uyar R (2011) Determination of antimicrobial and antiproliferative activities of the aquatic moss Fontinalis antipyretica Hedw. Turk J Biol 35:361-369

Saxena S, Meshram V, Kapoor N (2015) Muscodor tigerii sp. nov.-volatile antibiotic producing endophytic fungus from the Northeastern Himalayas. Ann Microbiol 65(1):47-57

Saxena S, Meshram V, Kapoor N (2014) Muscodor darjeelingensis, a new endophytic fungus of Cinnamomum camphora collected from northeastern Himalayas. Sydowia 66(1):55-67

Scher JM, Speakman JB, ZApp J, Becker H (2004) Bioactivity guided isolation of antifungal compounds from the liverwort Bazzania trilobata (L.) S. F Gray. Phytochemistry 65:2583-2588

Schmelz EA, Huffaker A, Sims JW, Christensen SA, Lu X, Okada K, Peters RJ (2014) Biosynthesis, elicitation and roles of monocot terpenoid phytoalexins. Plant J 79:659-678

Schulz B, Sucker J, Aust HJ, Krohen K, Ludewig K, Jones PG, Doring D (1995) Biologically active secondary metabolites of endophytic Pezicula sp. Mycol Res 99:1007-1015

Scott FE, Simpson TJ, Trimble LA, Vederas JCJ (1984) Chem Soc Chem Commun 12:756-758

Shain L, Miller JB (1982) Pinocembrin: an antifungal compound secreted by leaf glands of eastern cottonwood. Phytopathology 72:877-880

Shan W, Zhou Y, Liu H, Yu X (2018) Endophytic actinomycetes from tea plants (Camellia sinensis): isolation, abundance, antimicrobial, and plant-growth-promoting activities. Hindawi BioMed Research 2018:1-12

Shanahan P, O'Sullivan DJ, Simpson P, Glennon JD, O'Gara F (1992) Isolation of 2,4-Diacetylphloroglucinol from a fluorescent pseudomonad and investigation of physiological parameters influencing its production. Appl Environ Microbiol 58:353-358

Sharma HSS, Fleming C, Selby C, Rao JR, Martin T (2014) Plant bio-stimulants: a review on the processing of macroalgae and use of extracts for crop management to reduce abiotic and biotic stresses. J Appl Phycol 26:465-490

Sharp JK, Valent B, Albersheim P (1984) Purification and partial characterization of a b-glucan fragment that elicits phytoalexin accumulation in soybean. J Biol Chem 259:11312-11320

Shen X-Y, Cheng Y-L, Cai C-J, Fan L, Gao J et al (2014) Diversity and antimicrobial activity of Culturable Endophytic Fungi isolated from Moso bamboo seeds. PLoS One 9(4):e95838

Shimizu M (2011) Endophytic actinomycetes: biocontrol agents and growth promoters. In: Maheshwari DK (ed) Bacteria in agrobiology: plant growth responses. Elsevier Academic Press, San Diego, pp 201-220 
Shimizu M, Nakagawa Y, Sato Y, Furumai T, Igarashi Y, Onaka H, Yoshida R, Kunoh H (2000) Studies on endophytic actinomycetes (I) Streptomyces sp. isolated from rhododendron and its antifungal activity. J Gean Plant Pathol 66:360-366

Shirzadian S, Afshari Azad H, Khalghani J (2009) Introduction study of antifungal activities of bryophyte extracts. Iran J Plant Pest Dis 77:1-22

Shlezinger N, Minz A, Gur Y, Hatam I, Dagdas YF, Talbot NJ, Sharon A (2011) Anti-apoptotic machinery protects the necrotrophic fungus Botrytis cinerea from host-induced apoptotic-like cell death during plant infection. PLoS Pathog 7:1002185

Shutsrirung A, Chromkaew Y, Pathom-Aree W, Choonluchanon S, Boonkerd N (2014) Diversity of endophytic actinomycetes in mandarin grown in northern Thailand, their phytohormone production potential and plant growth promoting activity. Soil Sci Plant Nutr 59(3):322-330

Silva-Hughesa AF, Wedgeb DE, Cantrellb CL, Carvalhoa CR, Panb Z, Moraesc RM, Madoxxe VL, Rosaa LH (2015) Diversity and antifungal activity of the endophytic fungi associated with the native medicinal cactus Opuntia humifusa (Cactaceae) from the United States. Microbiol Res 175:67-77

Singh AK, Pandey MB, Singh S, Singh AK, Singh UP (2008) Antifungal activity of securinine against some plant pathogenic fungi. Mycobiology 36:99-101

Singh M, Rawat AK, Govindarajan R (2007) Antimicrobial activity of some Indian mosses. Fitoterapia 78:156-158

Singh R, Kalra A, Parameswaran TN, Srinivas KVNS et al (2012) Plant Pathol 61:700-708

Singh SK, Strobel GA, Knighton B, Geary B, Sears J, Ezra D (2011) An Endophytic Phomopsis sp. possessing bioactivity and fuel potential with its volatile organic compounds. Microb Ecol 61(4):729-739

Siri-udom S, Suwannarach N, Lumyong S (2016) Existence of Muscodor vitigenus, M. equiseti and M. heveae sp. nov. in leaves of the rubber tree (Hevea brasiliensis Müll. Arg.), and their biocontrol potential. Ann Microbiol 66:437-448

Sitton D, West CA (1975) Casbene: an antifungal diterpene produced in cell-free extracts of Ricinus communis seedlings. Phytochemistry 14:1921-1925

Skaltsa H, Lazari D, Panagouleas C, Georgiadov E, Garcia B, Sokovic M (2000) Sesquiterpene lactones from Centaurea thessala and Centaurea attica: antifungal activity. Phytochemistry 55:903-908

Slusarenko AJ, Fraser RS, Van Loon LC (2012) Mechanisms of resistance to plant diseases. Springer, Dordrecht

Smith FA, Smith SE (2011) What is the significance of the arbuscular mycorrhizal colonisation of many economically important crop plants? Plant Soil 348:63-79

Smith GS (1988) The role of phosphorous nutrition in interactions of vesicular arbuscular mycorrhizal fungi with soil borne nematodes and fungi. Phytopathology 78:371-374

Smith KP, Havey MJ, Handelsman J (1993) Suppression of cottony leak of cucumber with Bacillus cereus strain UW85. Plant Dis 77:139-142

Smith SE, Gianinazzi Pearson V, Koide R et al (1994) Management of Mycorrhiza in agriculture, horticulture and forestry. Kluwer, Dordecht, pp 103-113

Song YC, Li H, Ye YH, Shan CY, Yang YM, Tan RX (2004) Endophytic naphthopyrone metabolites are co-inhibitors of xanthine oxidase, SW1116 cell and some microbial growths. FEMS Microbiol Lett 241:67-72

Sopalun K, Strobel GA, Wm H, Worapong J (2003) A record of Muscodor albus, an endophyte from Myristica fragrans in Thailand. Mycotaxon 88:239-247

Soundharrajan RS, Belusamy R, Ramasamy R, Selladurai M, Srinivasan N (2003) Antifungal activity of some essential oils. J Agric Food Chem 51:7596-7599

Spendley PJ, Bird PM, Ride JP, Leworthy DP (1982) Two novel antifungal alka-2,4-dienals from Triticum aestivum. Phytochemistry 21:2403-2404

Springob K, Kutchan TM (2009) Introduction to the different classes of natural products. In: Osbourn AE, Lanzotti V (eds) Plant-derived natural products synthesis, function, and application. Springer, New York, pp 3-50 
Srividya S, Thapa A, Bhat DV, Golmei K, Dey N (2012) Streptomyces sp. 9p as effective biocontrol against chilli soilborne fungal phytopathogens. Eur J Exp Biol 2(1):163-173

Stadnik MJ, Freitas MB (2014) Algal polysaccharides as source of plant resistance inducers. Trop Plant Pathol 39:111-118

St-Arnaud M, Vujanovic V (2007) Mycorrhizae in crop production. The Haworth Press, Inc, New York, pp 67-122

Stinson M, Ezra D, Hess WM, Sears J, Strobel G (2003) An endophytic Gliocladium sp. of Eucryphia cordifolia producing selective volatile antimicrobial compounds. Plant Sci 165:913-922

Stirk WA, Reinecke DL, van Staden J (2007) Seasonal variation in antifungal, antibacterial and acetyl cholinesterase activity in seven south African seaweeds. J Appl Phycol 19:271-276

Stoessl A (1980) Phytoalexins - a biogenetic perspective. J Phytopathol 99(3):251-272

Storck M, Sacristan MD (1995) The role of phytoalexins in the seedling resistance to Leptosphaeria maculans in some crucifers. Z Naturforsch 50c:15-20

Strobel GA, Spang S, Kluck K, Hess WM, Sears J, Livinghouse T (2008a) Synergism among volatile organic compounds resulting in increased antibiosis in Oidium sp. FEMS Microbiol Lett 283:140-145

Strobel G, Singh SK, Riyaz-Ul-Hassan S, Mitchell AM, Geary B, Sears J (2011) An endophytic/ pathogenic Phoma sp. from creosote bush producing biologically active volatile compounds having fuel potential. FEMS Microbiol Lett 320:87-94

Ul-Hassan R, Syed SG, Geary B, Sears J (2013) An Endophytic Nodulisporium sp. from Central America producing volatile organic compounds with both biological and fuel potential. J Microbiol Biotechnol 23(1):29-35

Strobel GA, Knighton B, Kluck K, Ren Y, Livinghouse T, Griffin M, Spakowicz D, Sears J (2008b) The production of mycodiesel hydrocarbons and their derivatives by the endophytic fungus Gliocladium roseum (NRRL 50072). Microbiology 154:3319-3328

Strobel GA, Kluck K, Hess WM, Sears J, Ezra D, Vargas PN (2007) Muscodor albus E-6, an endophyte of Guazuma ulmifolia making volatile antibiotics: isolation, characterization and experimental establishment in the host plant. Microbiology 153:2613-2620

Subhisha S, Subhramoniam A (2005) Antifungal activities of a steroid from Pallavicinia lyellii, a liverwort. Indian J Pharm 37:304-308

Sunilkumar G, Campbell LM, Pukhaber L, Stipanovic RD, Rathore KS (2006) Engineering cottonseed for use in human nutrition by tissue-specific reduction of toxic gossypol. Proc Natl Acad Sci 103:18054-18059

Suwannarach N, Bussaban B, Hyde KD, Lumyong S (2010) Muscodor cinnamomi, a new endophytic species from Cinnamomum bejolghota. Mycotaxon 15(114):15-23

Suwannarach N, Bussaban B, Nuangmek W, Pithakpol W, Jirawattanakul B, Matsui K, Lumyong S (2015) Evaluation of Muscodor suthepensis strain CMU-Cib462 as a postharvest biofumigant for tangerine fruit rot caused by Penicillium digitatum. J Sci Food Agric 96(1):339-345

Suwannarach N, Kumla J, Bussaban B, Hyde KD, Matsui K, Lumyong S (2013) Molecular and morphological evidence support four new species in the genus Muscodor from northern Thailand. Ann Microbiol 63:1341-1351

Suwannarach N, Kumla J, Bussaban B, Lumyong S (2012) Biocontrol of Rhizoctonia solani AG-2, the causal agent of damping-off by Muscodor cinnamomi CMU-Cib 461. World J Microbiol Biotechnol 28:3171-3177

Taechowisan T, Lu C, Shen Y, Lumyong S (2007) Antitumor activity of 4-arylcoumarins from endophytic Streptomyces aureofaciens CMUAc130. J Cancer Res Ther 3(2):86-91

Taechowisan T, Wanbanjob A, Tuntiwachwuttikul P, Taylor WC (2006) Identification of Streptomyces sp. Tc022, an endophyte in Alpinia galanga, and the isolation of actinomycin D. Ann Microbiol 56:113-117

Takasugi M (1979) Structures of moracins E, F, G and H, new phytoalexins from diseased mulberry. Tetrahedron Lett 28:4675-4678 
Takasugi M, Katsui N, Shirata A (1986) Isolation of three novel sulphur-containing phytoalexins from the Chinese cabbage Brassica campestris L. ssp. pekinensis (Cruciferae). J Chem Soc Chem Commun 14:1077-1078

Takasugi M, Monde K, Katsui N, Shirata A (1988) Novel sulfur-containing phytoalexins from the Chinese cabbage Brassica campestris L. ssp. pekinensis (Cruciferae). Bull Chem Soc Jpn 61:285-289

Tanaka N, Yamaguchi H, Umezawa H (1966) Mechanism of kasugamycin action on polypeptide synthesis. J Biochem 60:429

Tan HM, Cao LX, He ZF, Su GJ, Lin B, Zhou SN (2006) Isolation of endophytic actinomycetes from different cultivars of tomato and their activities against Ralstonia solanacearum in vitro. World J Microbiol Biotechnol 22:1275-1280

Taware R, Abnave P, Patil D, Rajamohananan PR, Raja R, Soundararajan G, Kundu GC, Ahmad A (2014) Isolation, purification and characterization of Trichothecinol-A produced by endophytic fungus Trichothecium sp. and its antifungal, anticancer and antimetastatic activities. Sustainable Chem Processes 2:8

te Welscher YM, ten Napel HH, Balague MM, Souza CM, Riezman H, de Kruijff B, Breukink EJ (2008) Biol Chem 283:6393

Telaxka FJ, Jaski JM, Baldin D, Scariot E, Grosselli M, Moura GS (2014) Antibacterial activity and induction of phytoalexins in bean plants by homeopathic preparations of essential oil of Eucalyptus globulus. Congresso Paranaense de Agroecologia 9:1-5

Thomashow LS, Bonsall RF, Weller DM (2002) Antibiotic production by soil and rhizosphere microbes in situ. In: Manual of environmental microbiology, 2nd edn. ASM Press, Washington, DC, pp 638-647

Tian XL, Cao LX, Tan HM, Zeng QG, Jia YY, Han WQ, Zhou SH (2004) Study on the communities of endophytic fungi and endophytic actinomycetes from rice and their antipathogenic activities in vitro. World J Microbiol Biotechnol 20:303-309

Ting ASY, Mah SW, TEE CS (2010) Identification of volatile metabolites from fungal endophytes with biocontrol potential towards Fusarium Oxysporum F. sp. cubense race 4. Am J Agric Biol Sci 5(2):177-182

Toljander JF, Lindahl BD, Paul LR, Elfstr MA, Finlay RD (2007) Influence of arbuscular mycorrhizal mycelial exudates on soil bacterial growth and community structure. FEMS Microbiol Ecol 61:295-304

Toral L, Rodriguez M, Bejar V, Sampedro I (2018) Antifungal activity of Lipopeptides from Bacillus XT1 CECT 8661 against Botrytis cinerea. Front Microbiol 9:1315

Tomsheck AR, Strobel GA, Booth E, Geary B, Spakowicz D, Knighton B, Floerchinger C, Sears J, Liarzi O, Ezra D (2010) Hypoxylon sp., an Endophyte of Persea indica, producing 1,8-cineole and other bioactive volatiles with fuel potential. Microb Ecol 60:903-914

Toyomasu T et al (2008) Diterpene phytoalexins are biosynthesized in and exuded from the roots of rice seedlings. Biosci Biotechnol Biochem 72(2):562-567

Tsuji J, Zook M, Jackson EP, Cage DA, Hammerschmidt R, Somerville S (1992) Plant Physiol 98:1304

Tzortzakis NG, Economakis CD (2007) Antifungal activity of lemongrass (Cymbopogon citratus L.) essential oil against key postharvest pathogens. Innov Food Sci Emerg Technol 8:253-258

Vanden B, DRomer HF, Improvisi I, Lozano-Chiu M, Rex JH, Sanglard D (1998) Antifungal drug resistance in pathogenic fungi. Med Mycol 36:119-128

Ulloa-Benítez Á, Medina-Romero YM, Sánchez-Fernández RE, Lappe-Oliveras P, Roque-Flores G, Duarte Lisci G, Herrera Suárez T, Macías-Rubalcava ML (2016) Phytotoxic and antimicrobial activity of volatile and semi-volatile organic compounds from the endophyte Hypoxylon anthochroum strain Blaci isolated from Bursera lancifolia (Burseraceae). J Appl Microbiol 121(2):380-400

Romero YMM, Flores GR, Rubalcava MLM (2017) Volatile organic compounds from endophytic fungi as innovative postharvest control of Fusarium oxysporum in cherry tomato fruits. Appl Microbiol Biotechnol 101:8209-8222 
VanEtten HD, Bateman DF (1971) Studies on the mode of action of the phytoalexin phaseolin. Phytopathology 61:1363-1372

VanWees SC, Chang HS, Zhu T, Glazebrook J (2003) Characterization of the early response of Arabidopsis to Alternaria brassicicola infection using expression profiling. Plant Physiol 132:606-617

Veljic M, Durie A, Sokovic M, Ciric A, Glamochja J, Marin PD (2009) Antimicrobial activity of methanol extracts of Fontinalis Antipyretica, Hypnum Cupressiforme and Ctenidium molluscum. Arch Biol Sci 61:225-229

Vera J, Castro J, Gonzalez A, Moenne A (2011) Sea weed polysaccharides and derived oligosaccharides stimulate defense responses and protection against pathogens in plants. Mar Drugs 9:2514-2525

Verma VC, Surendra KG, Kumar A, Mishra A, Kharwar RN, Gange AC (2009) Endophytic Actinomycetes from Azadirachta indica a. Juss.: Isolation, Diversity, and anti-microbial activity. Microb Ecol 57(4):749-756

Vierheilig H, Steinkellner S, Khaosaad T (2008) The biocontrol effect of mycorrhization on soil borne fungal pathogens and the autoregulation of the AM symbiosis: one mechanism, two effects? In: Varma A (ed) Mycorrhiza. Springer, Berlin, pp 307-320

Vigo C, Norman JR, Hooker JE (2000) Biocontrol of the pathogen Phytophthora parasitica by arbuscular mycorrhizal fungi is a consequence of effects on infection loci. Plant Pathol 49:509-514

Viturro CF, Dela-Fuente JR, Maier MS (2004) 5-Methylcoumaranones from Mutisia friesiana and their bioactivity. J Nat Prod 67:778

Volpin H, Elkind Y, Okon Y, Kapulnik Y (1994) A vesicular Arbuscular Mycorrhizal fungus (Glomus intraradix) induces a Defense response in alfalfa roots. Plant Physiol 104:683-689

Volpin H, Phillips DA, Okon Y, Kapulnik Y (1995) Suppression of an Isoflavonoid Phytoalexin Defense response in Mycorrhizal alfalfa roots. Plant Physiol 108(4):1449-1454

Vos CM, Yang Y, De Coninck B, Cammue BPA (2014) Fungal (-like) biocontrol organisms in tomato disease control. Biol Control 74:65-81

Walters DR, Ratsep J, Havis ND (2013) Controlling crop diseases using induced resistance: challenges for the future. J Exp Bot 64:1263-1280

Wang SY, Chen PF, Chang ST (2005) Antifungal activities of essential oils and their constituents from indigenous cinnamon (Cinnamomum osmophloeum) leaves against wood decay fungi. Bioresour Technol 96:813-818

Wang X, Manrang Z, Gao J, Pu T, Bilal M, Wang Y, Zhang X (2018) Antifungal activity screening of soil actinobacteria isolated from Inner Mongolia, China. Biol Control 127:78-84

Wang Y, Wang G, Wang L, Xu X, Xia J, Huang X, Wu Y, Zhang C (2010) Isolation and identification of an endophytic fungus of Polygonatum cyrtonema and its antifungal metabolites. Wei Sheng Wu Xue Bao 50:1036-1043

Ward EWB et al (1975) Loroglossol: an orchid phytoalexin. Phytopathology 65:632-633

Wasimfiroz RM, Hosagoudar GN, Narayanaswamy H, Patil B (2018) Evaluation of fungicides, bio-agents and plant extracts against Pyricularia oryzae. Int J Chem Stud 6(2):1875-1879

Wei ZM, Laby RJ, Zurnoff CH, Bauer DW, He SY, Collmer A, Beer SV (1992) Science 257:85

Wharton P, Nicholson R (2000) Temporal synthesis and radiolabelling of the sorghum 3-deoxyanthocyanidin phytoalexins and the anthocyanin, cyanidin 3-dimalonyl glucoside. New Phytopatol 145:457-469

Wilhite SE, Lunsden RD, Strancy DC (2001) Peptide synthetase gene in Trichoderma virens. Appl Environ Microbiol 67:5055-5062

Williams ST, Davies FL (1965) Use of antibiotics for selective isolation and enumeration of actinomycetes in soil. J Gen Microbiol 38:251-262

Wippich C, Wink M (1985) Biological properties of alkaloids. Influence of quinolizidine alkaloids and gramine on the germination and development of Powderly mildew, Erysiphe graminis $\mathrm{f}$. sp. hordei. Experientia 41:1477-1479

Wolters B (1964) Die Verbreitung antifungaler Eigenschaften bei Moosen. Planta 62:88-96 
Woodward S, Pearce RN (1988) The role of stilbenes in resistance of Sitka spruce (Picea sitchensis (bong) Carr) to entry of fungal pathogens. Physiol Mol Plant Pathol 33:127

Worapong J, Strobel G, Daisy B, Castillo UF, Baird G, Hess WM (2002) Muscodor roseus anam. Sp. nov., an endophyte from Grevillea pteridifolia. Mycotaxon 81:463-475

Worapong J, Strobel GA, Ford EJ, Li JY, Baird G, Hess WM (2001) Muscodor albus anam. Sp. Nov., an endophyte from Cinnamomum zeylanicum. Mycotaxon 79:67-79

Xie CF, Lou HX (2008) Chemical constituents from the Chinese bryophytes and their reversal of fungal resistance. Curr Org Chem 12:619-628

Xu Q, Wang J, Huang Y, Zheng Z, Song S, Zhang Y, Su W (2004) Metabolites from mangrove endophytic fungus Dothiorella sp. Acta Oceanol Sin 23:541-547

Yang MH, Wang JS, Luo JG, Wang XB, Kong LY (2009) Tetran or triterpenoids from Chisocheton paniculatus. J Nat Prod 72:2014-2018

Yao H, Tian S (2005) Effects of pre-and post-harvest application of salicylic acid or methyl jasmonate on inducing disease resistance of sweet cherry fruit in storage. Postharvest Biol Technol 35:253-262

Yao YQ, Lan F, Qiao YM, Wei JG, Huang RS, Li LB (2017) Endophytic fungi harbored in the root of Sophora tonkinensis Gapnep: diversity and biocontrol potential against phytopathogens. Microbiol Open 6:e437

Yemele-Bouberte M, Krohn K, Hussain H, Dongo E, Schulz B, Hu Q (2006) Tithoniamarin and tithoniamide: a structurally unique isocoumarin dimer and a new ceramide from Tithonia diversifolia. Nat Prod Res 20:842-849

Yoganandam GP, Gowri R, Biswas D (2009) Evaluation of Wedelia Biflora (Linn) D.C for anthelmintic and antimicrobial activity. J Pharm Res 2:375-377

Yoon MY, Cha B, Kim JC (2013) Recent trends in studies on botanical fungicides in agriculture. Plant Pathol J 29(1):1-9

Yoon MY, Choi GJ, Choi YH, Jang KS, Park MS, Cha B, Kim JC (2010) Effect of polyacetylenic acids from Prunella vulgaris on various plant pathogens. Lett Appl Microbiol 51:511-517

Yoon MY, Choi NH, Min BS, Choi GJ, Choi YH, Jang KS, Han SS, Cha B, Kim JC (2011) Potent in vivo antifungal activity against powdery mildews of pregnane glycosides from the roots of Cynanchum wilfordii. J Agric Food Chem 59:12210-12216

Young MCM, Braga MR, Dietrich SMC, Gottlieb HE, Trevisan LMV, Bolzani VS (1992) Fungitoxic non-glycosidic iridoids from Alibertia macrophylla. Phytochemistry 31:3433

Yu J, Wu Y, He Z, Li M, Zhu K, Gao B (2018) Diversity and antifungal activity of endophytic fungi associated with Camellia oleifera. Mycobiology 46(2):85-91

Yuan Y, Feng H, Wang L, Li Z, Shi Y, Zhao L et al (2017) Potential of Endophytic Fungi isolated from cotton roots for biological control against Verticillium wilt disease. PLoS One 12(1): 0170557

Zaker M (2016) Natural plant products as eco-friendly fungicides for plant diseases control-a review. Agriculturists 14(1):134-141

Zernova OV, Lygin AV, Pawlowski ML, Hill CB, Hartman GL, Widholm JM, Lozovaya VV (2014) Regulation of plant immunity through modulation of phytoalexin synthesis. Molecules 19:7480-7496

Zhang J, Wang JD, Liu CX, Yuan JH, Wang XJ, Xiang WS (2014) A new prenylated indole derivative from endophytic actinobacteria Streptomyces sp. neau-D50. Nat Prod Res 28(7):431-437

Zhang JF, Li YB, Li CL, Jiang JQ (2006) Studies on chemical constituents in root tuber of Cynanchum auriculatum. Zhongguo Zhong Yao Za Zhi 31:814-816

Zhang CL, Wang GP, Mao LJ, Komon-Zelazowska M, Yuan ZL, lin FC, Drzhinina IS, Kubicek CP (2010) Muscodor fengyangensis sp. nov. from Southeast China: morphology, physiology and production of volatile compounds. Fungal Biol 114:797-808

Zhang W, Krohn K, Draeger S, Schulz B (2008) Bioactive isocoumarins isolated from the endophytic fungus Microdochium bolleyi. J Nat Prod 71:1078-1081

Zhao G, Zhao J, Peng L, Zou L, Wang J, Zhong L, Xiang D (2012) Effects of yeast polysaccharide on growth and flavonoid accumulation in Fagopyrum tataricum sprout cultures. Molecules $17: 11335-11345$ 
Zhao K, Li J, Shen M, Chen Q, Liu M, Ao X, Liao D, Gu Y, Xu K, Ma M, Yu X, Xiang Q, Chen J, Zhang X, Penttinen P (2018) Actinobacteria associated with chinaberry tree are diverse and show antimicrobial activity. Sci Rep 8:11103

Zhao K, Penttinen P, Guan T, Xiao J, Chen Q, Xu J et al (2011) The diversity and anti-microbial activity of endophytic actinomycetes isolated from medicinal plants in Panxi plateau China. Curr Microbiol 62:182-190

Zheng Y, Sheng J, Zhao R, Zhang J, Lv S, Liu L, Shen L (2011) Preharvest 1 -arginine treatment induced postharvest disease resistance to Botrytis cinerea in tomato fruits. J Agric Food Chem 59:6543-6549

Zhou CX, Liu JY, Ye WC, Liu CH, Tang RX (2003) Neoverataline a and B, two antifungal alkaloids with a novel carbon skeleton from Veratrum taliense. Tetrahedron 59:5743-5747

Zin NM, Sarmin NIM, Ghadin N, Basri DF, Sidik NM, Hess WM, Strobel GA (2007) Bioactive endophytic streptomycetes from the Malay peninsula. FEMS Microbiol Lett 274:83-88

Zook M, Leege L, Jackson D, Hammerschmidt R (1998) Camalexin accumulation in Arabis lyrata. Phytochemistry 49:2287-2289

Zou WX, Meng JC, Lu H, Chen GX, Shi GX, Zhang TY, Tan RX (2000) Metabolites of Colletotrichum gloeosporioides, an endophytic fungus in Artemisia mongolica. J Nat Prod 63:1529-1530 